\title{
11. NOTES ON NEOGENE CALCAREOUS NANNOFOSSIL BIOSTRATIGRAPHY OF THE ONTONG JAVA PLATEAU AND SIZE VARIATIONS OF RETICULOFENESTRA COCCOLITHS ${ }^{1}$
}

\author{
Toshiaki Takayama ${ }^{2}$
}

\begin{abstract}
A total of 35 calcareous nannofossil datums were found in the Neogene sediments recovered at five sites (Sites 803-807) on the Ontong Java Plateau in the equatorial Pacific during Ocean Drilling Program Leg 130. Among them, 12 datums in the Pleistocene-upper Pliocene sequences were correlated with magnetostratigraphy. Pliocene and Miocene calcareous nannofossil assemblages in 289 samples obtained from Holes $804 \mathrm{C}, 805 \mathrm{~B}, 805 \mathrm{C}$, and $806 \mathrm{~B}$ were studied. Reticulofenestra coccolith size distribution patterns in these Pliocene-Miocene sediments were also revealed through the present investigation.
\end{abstract}

\section{INTRODUCTION}

Leg 130 of the Ocean Drilling Program (ODP) began at Apra, Guam, on 23 January 1990 and ended at the same harbor on 26 March 1990. Over $4800 \mathrm{~m}$ of core were recovered from 16 holes drilled at 5 sites along a depth transect on the Ontong Java Plateau (Fig. 1 and Table 1).

This report deals with the study of the calcareous nannofossils recovered from the Neogene sequences at the Ontong Java Plateau sites drilled during Leg 130 (Sites 803 through 807). Its main purposes are (1) to present the calcareous nannofossil datums in the Neogene sequences, (2) to discuss the basis for the biostratigraphic age assignments at all sites, and (3) to describe in detail the Pliocene and Miocene calcareous nannofossil assemblages in Holes 804C, 805B, $805 \mathrm{C}$, and $806 \mathrm{~B}$.

In 1990, Young presented data on Reticulofenestra coccolith size distribution patterns in middle Miocene to Pliocene samples from the western Indian Ocean and the Red Sea. This data clearly showed a dramatic size reduction event occurring in the late Miocene nannofossil Zone NN10 of Martini's (1971) zonal scheme. Another main object of the present investigation is to present data on size variation of Pliocene-Miocene Reticulofenestra coccoliths at Sites 804, 805, and 806 as Young's report (1990).

\section{METHODS}

Standard smear slides were made for all samples using either ENTELLAN new or Eukitt as a mounting medium. The calcareous nannofossils were examined in the smear slides by standard light microscopy techniques (plane polarized light and/or cross polarized light at approximately $1500 \times$ magnification). For the Pliocene-Miocene samples only from Holes $804 \mathrm{C}, 805 \mathrm{~B}, 805 \mathrm{C}$, and 806B, counts of 200 specimens per sample were made in straight transects across the smear slides and were listed to determine the relative frequencies of occurrence of the species and their stratigraphic changes. The counts did not include Florisphaera profunda. After this examination, these slides were continuously scanned for the presence of other important species.

\footnotetext{
${ }^{1}$ Berger, W.H., Kroenke, L.W., Mayer, L.A., et al., 1993. Proc. ODP, Sci. Results, 130: College Station, TX (Ocean Drilling Program).

${ }^{2}$ Department of Geology, College of Liberal Arts, Kanazawa University, 1-1 Marunouchi, Kanazawa 920, Japan.
}

\section{ZONES AND DATUMS}

\section{Zones}

From the several calcareous nannofossil zonal schemes available for the subdivision of Cenozoic sediments (e.g., Martini, 1971; Okada and Bukry, 1980), I chose the scheme proposed by Martini (1971). His scheme does not represent the ultimate resolution that can be achieved in Cenozoic deep-sea sediments, because deep-sea biostratigraphy has developed rapidly over the past two decades and still continues to do so. However, this zonal scheme does provide a simple picture of biostratigraphic relationships in the cored sequences. I also think that the fact that most marine geologists are familiar with Martini's scheme also adds to its value as an initial framework for Leg 130 nannofossil biostratigraphy.

\section{Datums}

Table 2 summarizes the nannofossil datums considered in this report and their estimated ages. Among them, a total of 35 datums are useful for the Neogene sequences. As a matter of convenience, I will number these datums in descending order from 1 to 35 . Some of these datums are used as boundary markers for of Martini's (1971) zonation. However, the others are not in Martini's zonal boundary definitions. These additional events represent a resource that creates a substantially improved biostratigraphic and biochronologic resolution, which becomes important, for example, in the reconstruction of Cenozoic sediment accumulation rates.

\section{BIOSTRATIGRAPHIC SUMMARY}

During Leg 130, a total of 16 holes were drilled at 5 sites (Sites 803-807) along a depth transect on the Ontong Java Plateau, equatorial Pacific Ocean (Fig. 1 and Table 1). Cenozoic sediments were recovered primarily by continuous advanced hydraulic piston coring (APC) and use of the extended core barrel (XCB) after the refusal of the APC. Very abundant and moderately preserved coccoliths and discoasters were found throughout the cores studied.

\section{Pleistocene}

With regard to Pleistocene sequences, I only tried to detect the calcareous nannofossil datums at all sites. The stratigraphic positions of these datums are tabulated in Tables 3-7. Pleistocene magneto- and biostratigraphic relationships for each site are shown in Figure 2. The magnetostratigraphy in this area is not well established and is still 


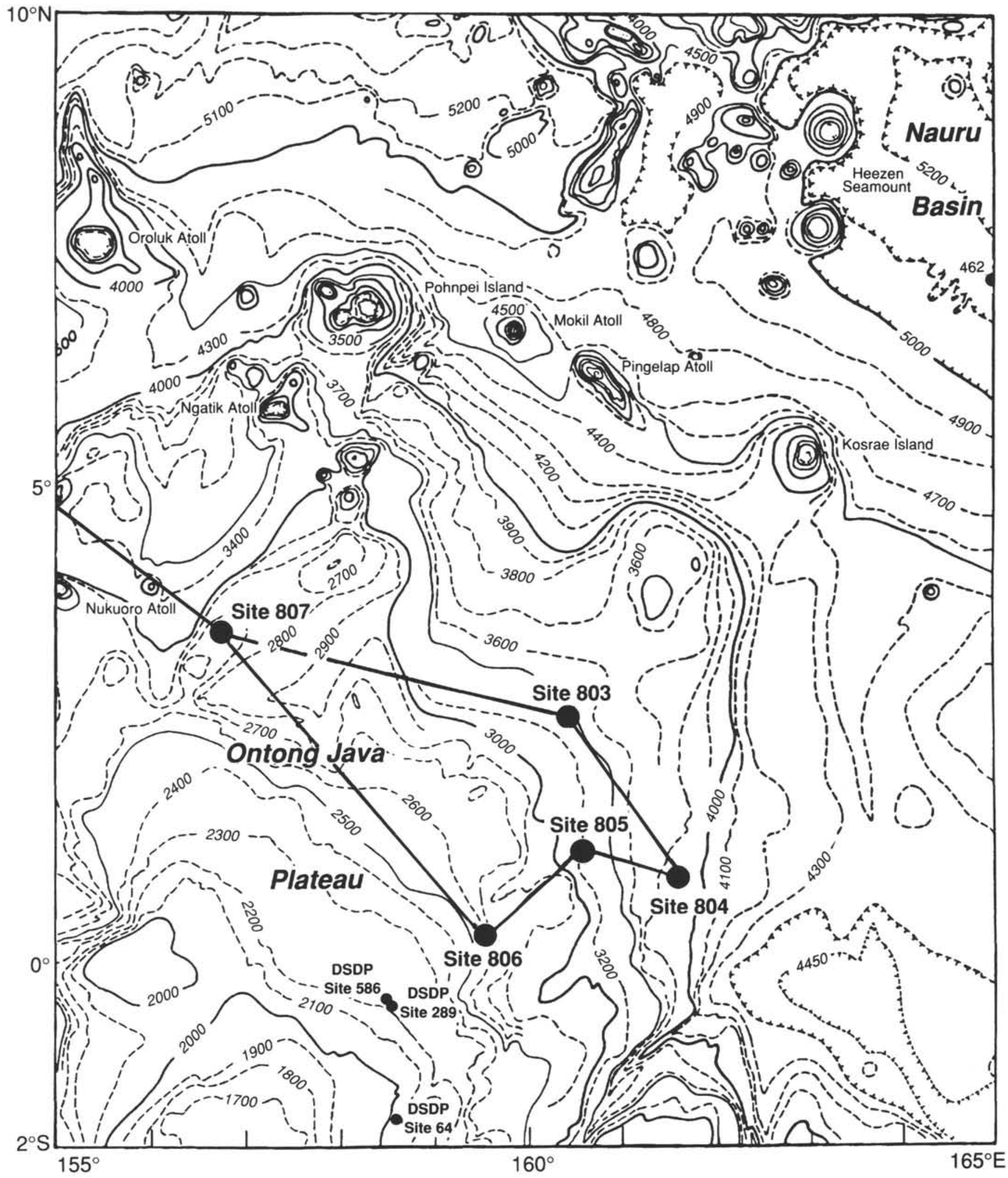

Figure 1. Bathymetric map (in meters) of the northwestern part of the Ontong Java Plateau (after Mammerickx and Smith, 1985) and locations of Leg 130 drill sites. Sites drilled on DSDP Leg 7 (Site 64), Leg 30 (Site 289), and Leg 89 (Site 586) are also provided for reference. 
Table 1. Locations of Leg 130 holes studied.

\begin{tabular}{cccc}
\hline Holes & Latitude & Longitude & $\begin{array}{c}\text { Water depth } \\
(\mathrm{m})\end{array}$ \\
\hline $803 \mathrm{D}$ & $2^{\circ} 25.98^{\prime} \mathrm{E}$ & $160^{\circ} 32.46^{\prime} \mathrm{E}$ & 3412.2 \\
$804 \mathrm{C}$ & $1^{\circ} 00.28^{\prime} \mathrm{N}$ & $161^{\circ} 35.62^{\prime} \mathrm{E}$ & 3861.1 \\
$805 \mathrm{~B}$ & $1^{\circ} 13.68^{\prime} \mathrm{N}$ & $160^{\circ} 31.76^{\prime} \mathrm{E}$ & 3186.8 \\
$805 \mathrm{C}$ & $1^{\circ} 13.69^{\prime} \mathrm{N}$ & $160^{\circ} 31.77^{\prime} \mathrm{E}$ & 3187.7 \\
$806 \mathrm{~B}$ & $0^{\circ} 19.11^{\prime} \mathrm{N}$ & $159^{\circ} 21.69^{\prime} \mathrm{E}$ & 2519.9 \\
$807 \mathrm{~A}$ & $3^{*} 36.42^{\prime} \mathrm{N}$ & $156^{\circ} 37.49^{\prime} \mathrm{E}$ & 2803.8 \\
\hline
\end{tabular}

tentative. Therefore, the relationship between the magnetostratigraphy and biostratigraphy is not clear. As is evident from Figure 2, however, Datum 4 FAD (first appearance datum) of Gephyrocapsa parallela is detected somewhere around the estimated Jaramillo Event and the Datum 11 FAD of Gephyrocapsa caribbeanica may be placed slightly above the estimâted Olduvai Event.

\section{Pliocene/Pleistocene Boundary}

The paleontological investigation of the Vrica section in Italy, which is the boundary stratotype for the base of the Pleistocene series, was conducted by many workers. Among these various investigations, Sato et al. (1988) concluded as follows:

Because reworked discoasters are present throughout the Pliocene-Pleistocene sequence at the Vrica section, the position of LAD (last appearance datum) Discoaster brouweri (Datum 12 in this chapter) is not clear. Therefore, the most reliable and nearest datum to the Pliocene/Pleistocene boundary is the FAD of Gephyrocapsa caribbeanica (Datum 11 in this chapter). This datum is about $20 \mathrm{~m}$ above the Pliocene/Pleistocene boundary and about $30 \mathrm{~m}$ above the top of the Olduvai Event. One can conclude that it is better to use the FAD of Gephyrocapsa caribbeanica as the Pliocene/Pleistocene boundary marker instead of LAD Discoaster brouweri.

Based on this evidence, the Pliocene/Pleistocene boundary in the holes studied is placed slightly below Datum 11 (FAD Gephyrocapsa caribbeanica). As is obvious from Tables 3-7, for example, this boundary in Holes $804 \mathrm{C}, 805 \mathrm{C}$, and $806 \mathrm{~B}$ can be detected in Cores $130-804 \mathrm{C}-3 \mathrm{H}, 130-805 \mathrm{C}-4 \mathrm{H}$, and 130-806B-5H, respectively.

\section{Pliocene and Miocene}

At the start, I detected the important calcareous nannofossil datums (Table 2) in the Pliocene and Miocene sequences at all sites. The stratigraphic positions of these datums are given in Tables 8-13 and illustrated in Figure 3 . Then I described successively the sequential changes of the calcareous nannofossil assemblages at selected sites; that is, at the shallowest (Site 806), intermediate (Site 805), and deepest (Site 804) sites, based on two samples including core-catcher materials from each core. Occurrence tables were prepared for these selected sites (Tables 14-17). These tables show the number of coccoliths counted at random in each sample during the 200 -specimen count; a plus sign ( + ) indicates the trace of a species in a sample, and a question mark (?) indicates the questionable presence of a species.

The overall sequential changes of nannofossil floras throughout the Pliocene-Miocene sequences at Sites 806, 805, and 804 are illustrated in Figure 4. The stratigraphic changes of relative abundances of Coccolithus pelagicus (and its related forms such as C. miopelagicus), Cyclicargolithus floridanus, Discoaster spp., Sphenolithus spp. and Reticulofenestra spp., which are dominant and important groups of the calcareous nannofossils at these selected sites are shown separately in Figures 5-9. As a matter of course, the pattern of floral changes at Sites 806,805 , and 804 are quite similar to each other.

Based on these floral changes, the Pliocene-Miocene sequence at the Ontong Java Plateau was divided into three parts: upper, middle, and lower. As evident from Figure 9, the upper part of the Pliocene-
Miocene sequence (NN18-NN10) is characterized by the remarkable dominance of Reticulofenestra specimens. It is noteworthy that the lower half of the upper part contains abundant sphenoliths (Fig. 8). At the boundary between the upper and the middle parts, the relative abundance of Reticulofenestra specimens decreases abruptly and becomes almost barren (Fig. 9); as a result, sphenoliths become dramatically dominant. Therefore, this horizon is characterized by the bloomlike abundance of small Sphenolithus abies (Fig. 8). In the middle part of the Neogene sequence (NN10-middle NN5/NN4), very abundant Reticulofenestra occurs again together with Coccolithus pelagicus and such related forms as $C$. miopelagicus (Figs. 5 and 9). In the lower half of the middle part, Cyclicargolithus floridanus and discoasters increase their relative abundances (Figs. 6 and 7). At the boundary between the middle and the lower parts, Reticulofenestra again becomes rare (Fig. 9); Cyclicargolithus floridanus and discoasters are abundant at this horizon (Figs 6 and 7). The lower part (middle NN5/NN4-NN1) is characterized by relatively diversified floras. However, the lower half of this part is characterized by fairly abundant Cyclicargolithus floridanus (Fig. 6).

The nannofossil assemblages at Sites 806,805 , and 804 are discussed in detail in what follows. Each calcareous nannofossil zone is considered separately, and biostratigraphic age assignments are discussed. As already mentioned above, nannofossil assemblages in Hole $806 \mathrm{~B}$ are quite similar to those in Holes 804C, 805B, and 805C. Therefore, I will describe the nannofossil floras in these holes, stressing those in the longest core from Hole 806B drilled at the shallowest site on the Ontong Java Plateau.

\section{Pliocene}

Lowest NN19 Pseudoemiliania lacunosa Zone (Datums 11-12)

Hole 806B: 35.5-42.39 mbsf; Samples 130-806B-5H-1, 26-27 cm, to $-5 \mathrm{H}-6,26-27 \mathrm{~cm}$

Hole 805C: 27.02-32.74 mbsf; Samples 130-805C-4H-1, 23-24 cm, to $-4 \mathrm{H}-5,23-24 \mathrm{~cm}$

Hole 804C: 16.67-18.85 mbsf; Samples 130-804C-3H-1, 90-91 cm, to $-3 \mathrm{H}-3,14-15 \mathrm{~cm}$

In the present investigation only two samples from Holes $805 \mathrm{C}$ and $806 \mathrm{~B}$ were available for the floral analysis. These samples contained neither Gephyrocapsa caribbeanica nor Discoaster brouweri and were assigned to the lowest NN19 Zone (latest Pliocene) (between Datum 11 FAD G. caribbeanica and Datum 12 LAD $D$. brouweri). The floras are characterized by very abundant small Reticulofenestra specimens and comparatively abundant Calcidiscus leptoporus. In Sample 130-805C-4H-5, 23-24 cm, small forms of Gephyrocapsa are abundant.

\section{NN18 Discoaster brouweri Zone (Datums 12-13)}

Hole 806B: 43.81-54.00 mbsf; Samples 130-806B-5H-7, 26-27 cm, to $-6 \mathrm{H}-\mathrm{CC}$

Hole 805C: 34.18-40.95 mbsf; Samples 130-805C-4H-6, 23-24 cm, to $-5 \mathrm{H}-4,23-24 \mathrm{~cm}$

Hole 804C: $19.22-25.30$ mbsf; Samples $130-804 C-3 H-3,52 \mathrm{~cm}$, to $-3 \mathrm{H}-\mathrm{CC}$

Based on the presence of Discoaster brouweri and the absence of $D$. pentaradiatus, the samples mentioned above were assigned to the late Pliocene NN18 Zone (between Datum 12 LAD D. brouweri and Datum 13 LAD D. pentaradiatus). In Samples 130-806B-5H-CC, 130-805C-4H-CC, and 130-804C-3H-CC, I also found Discoaster triradiatus. It is well known that the upper part of this zone is generally characterized by the abundant occurrence of this species (Takayama, 1969; Backman and Pestiaux, 1986; and others). In the holes studied, however, the acme of $D$. triradiatus was not recog- 
Table 2. Calcareous nannofossil datums and their assigned age estimates.

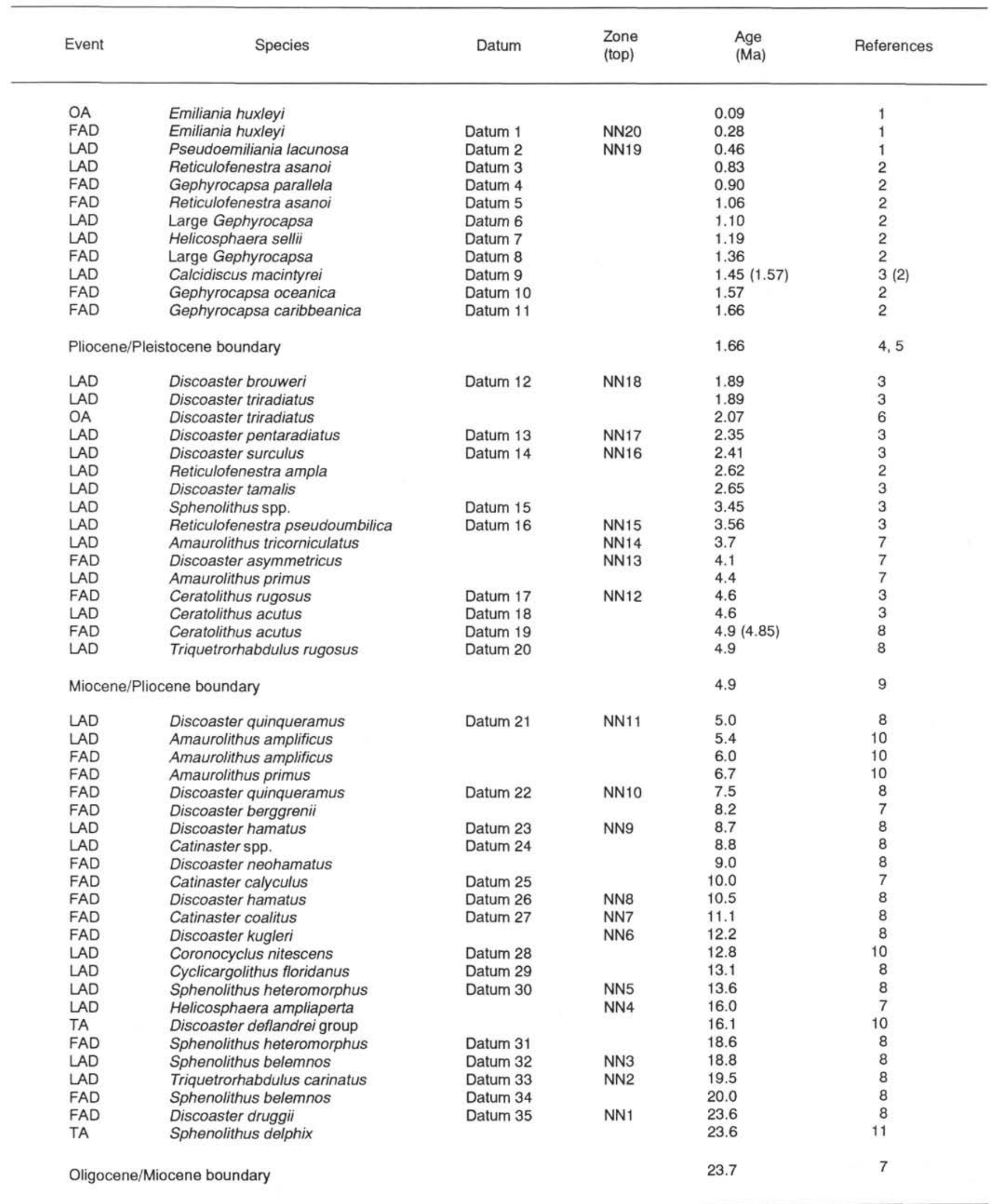

Notes: $\mathrm{FAD}=$ first appearance datum, $\mathrm{LAD}=$ last appearance datum, $\mathrm{OA}=$ onset acme, and $\mathrm{TA}=$ termination acme. Zonal codes are those of $\mathrm{Martini}(1971)$. Age column references represent (1) Thierstein et al. (1977); (2) Sato et al. (1991), Sato and Takayama (1992); (3) Backman and Shackleton (1983); (4) Sato et al. (1988); (5) Rio et al. (in press); (6) Backman and Pestiaux (1986); (7) Berggren et al. (1985); (8) Backman et al. (1990); (9) Zijderveld et al. (1986); (10) Rio et al. (1990); (11) Fornaciari et al. (1990). 


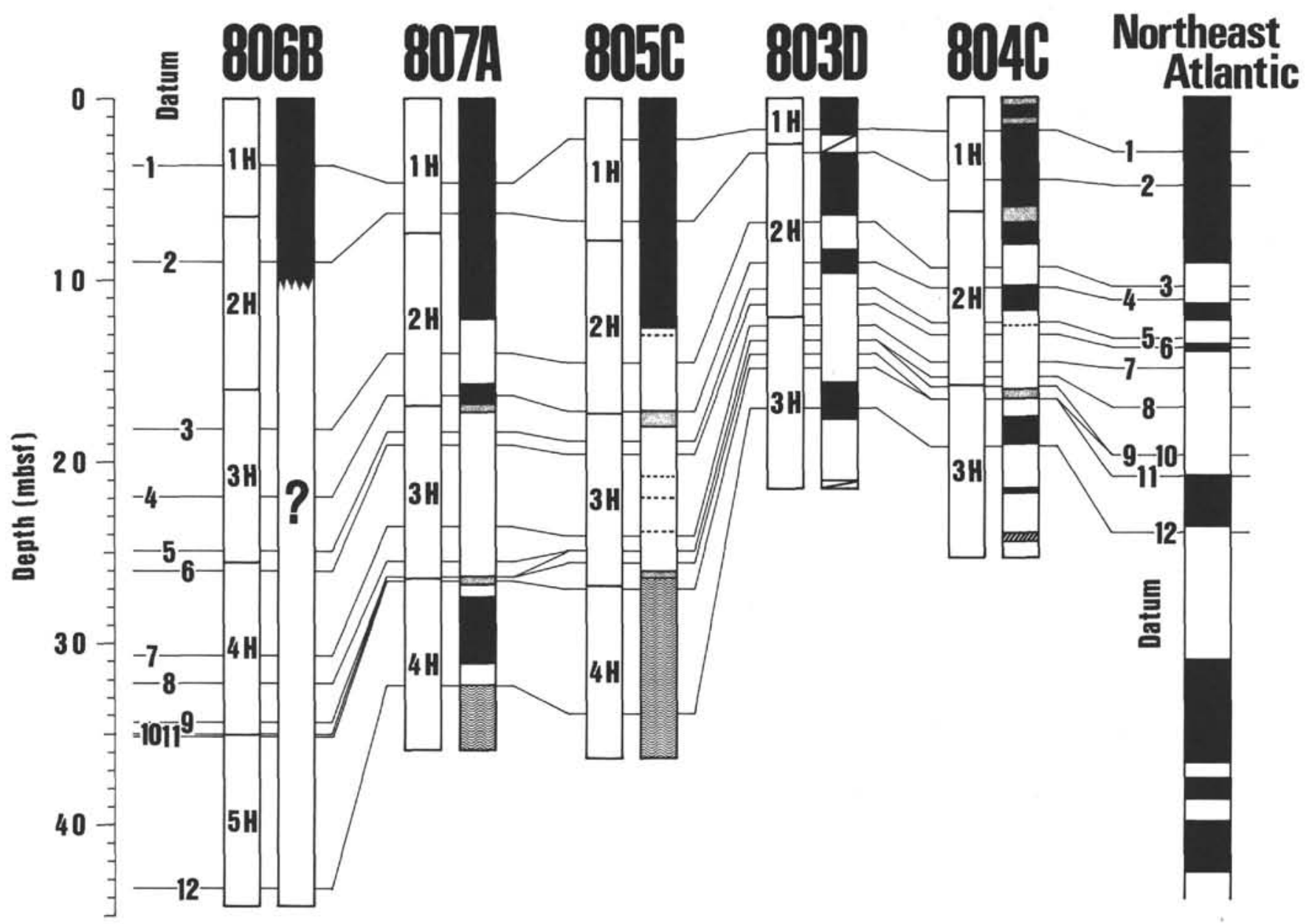

Figure 2. Quaternary magneto- and biostratigraphic relationships at each site of Leg 130 . Refer to Table 2 for key to datum numbers.

nized. In Hole 805C, Discoaster asymmetricus and D. blackstockae are present. In this zone, Reticulofenestra is very dominant; it forms nearly $75 \%$ of the flora in all samples. In Hole $805 \mathrm{C}$, a few specimens of Reticulofenestra pseudoumbilica were found (in Sample $130-805 \mathrm{C}-5 \mathrm{H}-3,23-24 \mathrm{~cm})$. However, it is considered to be reworked based on its state of preservation. Sporadic occurrences of Ceratolithus rugosus were also recognized.

\section{NN17 Discoaster pentaradiatus Zone (Datums 13-14)}

Hole 806B: 54.51-64.53 mbsf; Samples 130-806B-7H-1, 106$107 \mathrm{~cm}$, to $-8 \mathrm{H}-1,106-107 \mathrm{~cm}$

Hole 805C: 42.42-43.89 mbsf; Samples 130-805C-5H-5, 23-24 cm, to $-5 \mathrm{H}-6,23-24 \mathrm{~cm}$

Hole 804C: 29.01 mbsf; Sample 130-804C-4H-3, 90-91 cm

In the samples mentioned above, Discoaster brouweri and D. pentaradiatus co-occur. Small-sized Reticulofenestra specimens predominate. I observed the presence of Reticulofenestra pseudoumbilica in Sample $130-804 \mathrm{C}-4 \mathrm{H}-3,90-91 \mathrm{~cm}$. Judging from the state of the coccolith preservation, however, it is considered to be reworked. Sediments belonging to this zone (between Datum $13 \mathrm{LAD}$ D. pentaradiatus and Datum 14 LAD D. surculus) are very thin at all sites.

NN16 Discoaster surculus Zone (Datums 14-16)

Hole 806B: 65.99-93.66 mbsf; Samples 130-806B-8H-2, 106-107 $\mathrm{cm}$, to $-11 \mathrm{H}-2,26-27 \mathrm{~cm}$
Holes 805B and 805C: 45.80-73.20 mbsf; Samples 130-805C-5H$\mathrm{CC}$ to $130-805 \mathrm{~B}-8 \mathrm{H}-\mathrm{CC}$

Hole 804C: 30.44-34.80 mbsf; Samples 130-804C-4H-4, 90-91 cm, to $-4 \mathrm{H}-\mathrm{CC}$

In this zone, Discoaster surculus occurs for the first time. However, the upper part of this zone contains a few specimens of $D$. surculus. Consequently, it is difficult to detect the boundary between Zones NN17 and NN16 (Datum 14 LAD D. surculus). Samples from the lower part of this zone (such as Sample 130-806B-10H-CC, Samples 130-805B-8H-4, 23-24 cm, and -8H-CC, and Sample 130-804C-4HCC) yield such diversified discoaster species as Discoaster asymmetricus, $D$. brouweri, $D$. challengeri, $D$. decorus, $D$. surculus, $D$. triradiatus, and D. variabilis. Throughout this zone, Discoaster tamalis is almost absent. Moreover, only a few questionable specimens of Reticulofenestra ampla were observed in Samples 130-806B-8H-3, $106-107 \mathrm{~cm}$, and $-8 \mathrm{H}-\mathrm{CC}$. Therefore, calcareous nannofossil events LAD R. ampla and LAD D. tamalis were not detected at the Ontong Java Plateau. In some samples from the lower part of this zone (e.g., Sample 130-805B-8H-CC), Gephyrocapsa aperta and small specimens of Gephyrocapsa were found. In Holes 806B and 805B, Datum 15 (LAD Sphenolithus spp.) was detected at the lowest part of Zone NN16, slightly above Datum 16 (LAD Reticulofenestra pseudoumbilica). As same as overlying zones, reticulofenestrid specimens are very abundant throughout this interval. Reticulofenestra peudoumbilica occurs in Samples $130-805 \mathrm{C}-6 \mathrm{H}-4,23-24 \mathrm{~cm}$, and -6H-CC, 130-805B-7H-CC, and 130$804 \mathrm{C}-4 \mathrm{H}-\mathrm{CC}$ of this zone. Their numbers of specimen are limited; therefore, they are considered to be reworked. 
Table 3. Quaternary calcareous nannofossil datums, Hole 803D.

\begin{tabular}{|c|c|c|c|c|c|}
\hline \multicolumn{2}{|c|}{ Zone } & Species & $\begin{array}{l}\text { Age } \\
\text { (Ma) }\end{array}$ & $\begin{array}{l}\text { Core, section, } \\
\text { interval }(\mathrm{cm})\end{array}$ & Depth (mbsf) \\
\hline CN15 & NN21 & 1. FAD Emiliania huxleyi & 0.28 & $1 \mathrm{H}-1,90-91 / 1 \mathrm{H}-\mathrm{CC}$ & $0.89 / 2.50$ \\
\hline \multirow[t]{2}{*}{ CN14b } & \multirow{2}{*}{ NN20 } & \multirow[b]{2}{*}{ 2. LAD Pseudoemiliania lacunosa } & \multirow[b]{2}{*}{0.46} & \multirow{2}{*}{$2 \mathrm{H}-1,15-16 / 2 \mathrm{H}-1,90-91$} & \multirow[b]{2}{*}{$2.64 / 3.36$} \\
\hline & & & & & \\
\hline \multirow{8}{*}{ CN14a } & \multirow{9}{*}{ NN19 } & 3. LAD Reticulofenestra asanoi & 0.83 & $2 \mathrm{H}-3,90-91 / 2 \mathrm{H}-4,15-16$ & $6.23 / 6.95$ \\
\hline & & 4. FAD Gephyrocapsa parallela. & 0.90 & $2 \mathrm{H}-5,15-16 / 2 \mathrm{H}-5,90-91$ & $8.38 / 9.10$ \\
\hline & & 5. FAD Reticulofenestra asanoi & 1.06 & $2 \mathrm{H}-6,15-16 / 2 \mathrm{H}-6,90-91$ & $9.81 / 10.53$ \\
\hline & & 6. LAD LargeGephyrocapsa & 1.10 & $2 \mathrm{H}-6,90-91 / 2 \mathrm{H}-7,15-16$ & $10.53 / 11.25$ \\
\hline & & 7. LAD Helicosphaera sellii & 1.19 & $3 \mathrm{H}-1,15-16 / 3 \mathrm{H}-1,90-91$ & $12.14 / 12.87$ \\
\hline & & 8. FAD Large Gephyrocapsa & 1.36 & $3 \mathrm{H}-1,90-91 / 3 \mathrm{H}-2,15-16$ & $12.87 / 13.59$ \\
\hline & & 9. LAD Calcidiscus macintyrei & 1.45 & $3 \mathrm{H}-1,90-91 / 3 \mathrm{H}-2,15-16$ & $12.87 / 13.59$ \\
\hline & & 10. FAD Gephyrocapsa oceanica & 1.57 & $3 \mathrm{H}-2,15-16 / 3 \mathrm{H}-2,90-91$ & $13.59 / 14.32$ \\
\hline $\mathrm{CN} 13 \mathrm{~b}$ & & 11. FAD Gephyrocapsa caribbeanica & 1.66 & $3 \mathrm{H}-2,90-91 / 3 \mathrm{H}-3,15-16$ & $14.32 / 15.04$ \\
\hline CN13a & NN18 & 12. LAD Discoaster brouweri & 1.89 & $3 \mathrm{H}-4,15-16 / 3 \mathrm{H}-4,90-91$ & $16.49 / 17.21$ \\
\hline
\end{tabular}

NN15 Reticulofenestra pseudoumbilica Zone-NN13 Ceratolithus rugosus Zone (Datums 16-17)

Hole 806B: 95.08-137.43 mbsf; Samples 130-806B-11H-3, 26-27 $\mathrm{cm}$, to $-15 \mathrm{H}-6,26-27 \mathrm{~cm}$

Hole 805B: 73.42-104.93 mbsf; Samples 130-805B-9H-1, 23-24 $\mathrm{cm}$, to $-12 \mathrm{H}-3,23-24 \mathrm{~cm}$

Hole 804C: 39.48-44.30 mbsf; Samples 130-804C-5H-4, 90-91 cm, to $-5 \mathrm{H}-\mathrm{CC}$

Relatively abundant, very large-sized reticulofenestrid species, Reticulofenestra pseudoumbilica, and $R$. gelida occur in and below Zone NN15. As stated above, Reticulofenestra pseudoumbilica occurs in several samples of Zones NN18, NN17, and NN16. However, judging from the limited numbers of specimens and their preservation state, these Reticulofenestra pseudoumbilica are considered to be reworked. The interval from Zones NN15 through NN13 (between Datums 16 LAD R. pseudoumbilica and 17 FAD Ceratolithus rugosus) was not subdivided because members of Amaurolithus and Discoaster asymmetricus are rare or absent in this region. Therefore, I placed the above-mentioned samples tentatively in the NN15-NN13 zonal interval. As compared with the overlying zones, Reticulofenestra species decrease their numbers, but still they form more than $50 \%$ of the total flora in all samples (Fig. 9). Ceratolithus rugosus occurs almost throughout this zonal interval. Comparatively large-sized Discoaster variabilis is present in samples belonging to the upper part of this NN15-NN13 interval.

NN12 Amaurolithus tricorniculatus Zone (Datums 17-21)

Hole 806B: 138.87-161.60 mbsf; Samples 130-806B-15H-7, 26-27 $\mathrm{cm}$, to $-18 \mathrm{H}-3,26-27 \mathrm{~cm}$

Hole 805B: 106.43-120.92 mbsf; Samples 130-805B-12H-4, 23-24 $\mathrm{cm}$, to $-14 \mathrm{H}-1,23-24 \mathrm{~cm}$

Hole $804 \mathrm{C}$ : missing.

The above-mentioned samples are characterized by the absence of Ceratolithus rugosus and Discoaster quinqueramus and, therefore, are assigned to early Pliocene NN12 Zone (between Datum 17 FAD $C$. rugosus and Datum 21 LAD D. quinqueramus). In Hole 804C, this zone is completely missing; an early Pliocene hiatus is inferred at Site 804. As shown in Figure 8, some samples in this zone contain fairly abundant sphenoliths (e.g., in Samples 130-806B-16H-4, 26-27 cm, and -17HCC). Triquetrorhabdulus rugosus, whose LAD defines Datum 20, was found as high as Samples 130-806B-17H-4, 26-27 cm, and 130-805B$13 \mathrm{H}-\mathrm{CC}$. It is remarkable that the interval ranging from Samples 130$806 \mathrm{~B}-15 \mathrm{H}-\mathrm{CC}$ through - $16 \mathrm{H}-\mathrm{CC}$ and Samples $130-805 \mathrm{~B}-12 \mathrm{H}-4,23-24$ $\mathrm{cm}$, through -13H-3, 123-124 cm, contain Ceratolithus acutus. Therefore, we can detect the important Datums 18 and 19 above and below these sample intervals, respectively.

\section{Miocene}

NN11 Discoaster quinqueramus Zone (Datums 21-22)

Hole 806B: 163.02-283.65 mbsf; Samples 130-806B-18H-4, 26-27 $\mathrm{cm}$, to $-31 \mathrm{H}-2,24-25 \mathrm{~cm}$

Hole 805B: 122.36-218.82 mbsf; Samples 130-805B-14H-2, 23-24 $\mathrm{cm}$, to $-24 \mathrm{H}-3,23-24 \mathrm{~cm}$

Hole 804C: 44.63-71.45 mbsf; Samples 130-804C-6H-1, 90-91 cm, to $-8 \mathrm{H}-6,90-91 \mathrm{~cm}$

Judging from the existence of Discoaster quinqueramus, the above-mentioned samples were assigned to Zone NN11 (between Datums $21 \mathrm{LAD}$ D. quinqueramus and $22 \mathrm{FAD}$ D. quinqueramus). However, the characteristic central stem in this species is not so well developed in the oldest and youngest associations of this species, often making precise determination of its entry and exit levels difficult. The top of this zone (Datum 21) approximately indicates the position of the Miocene/Pliocene boundary. Discoaster berggrenii is also present throughout this interval. Calcidiscus premacintyrei occurs consistently in and below this zone, although the sporadic occurrences of this species were recognized in the overlying NN12 Zone. Amaurolithus specimens are consistently rare in the lower Pliocene and upper Miocene sediments, and primary morphological characters are typically masked by substantial calcite growth. Therefore, the $\mathrm{LAD}$ and FAD of 
Table 4. Quaternary calcareous nannofossil datums, Hole 804C.

\begin{tabular}{|c|c|c|c|c|c|}
\hline \multicolumn{2}{|c|}{ Zone } & Species & $\begin{array}{l}\text { Age } \\
\text { (Ma) }\end{array}$ & $\begin{array}{l}\text { Core, section, } \\
\text { interval }(\mathrm{cm})\end{array}$ & Depth (mbsf) \\
\hline CN15 & NN21 & 1. FAD Emiliania huxleyi & 0.28 & $1 \mathrm{H}-2,15-16 / 1 \mathrm{H}-2,52$ & $1.65 / 2.20$ \\
\hline CN14b & NN20 & 2. LAD Pseudoemiliania lacunosa & 0.46 & $1 \mathrm{H}-3,127 / 1 \mathrm{H}-4,15-16$ & $4.26 / 4.64$ \\
\hline \multirow{8}{*}{ CN14a } & \multirow{9}{*}{ NN19 } & 3. LAD Reticulofenestra asanoi & 0.83 & $2 \mathrm{H}-2,127 / 2 \mathrm{H}-3,15-16$ & $8.93 / 9.29$ \\
\hline & & 4. FAD Gephyrocapsa parallela. & 0.90 & $2 \mathrm{H}-3,90-91 / 2 \mathrm{H}-3,127$ & $10.00 / 10.36$ \\
\hline & & 5. FAD Reticulofenestra asanoi & 1.06 & $2 \mathrm{H}-4,127 / 2 \mathrm{H}-5,15-16$ & $11.78 / 12.14$ \\
\hline & & 6. LAD LargeGephyrocapsa & 1.10 & $2 \mathrm{H}-5,52 / 2 \mathrm{H}-5,90-91$ & $12.49 / 12.85$ \\
\hline & & 7. LAD Helicosphaera sellii & 1.19 & $2 \mathrm{H}-6,52 / 2 \mathrm{H}-6,90-91$ & $13.92 / 14.28$ \\
\hline & & 8. FAD Large Gephyrocapsa & 1.36 & $2 \mathrm{H}-6,127 / 2 \mathrm{H}-7,15-16$ & $14.63 / 14.99$ \\
\hline & & 9. LAD Calcidiscus macintyrei & 1.45 & $2 \mathrm{H}-7,65 / 2 \mathrm{H}-\mathrm{CC}$ & $15.34 / 15.80$ \\
\hline & & 10. FAD Gephyrocapsa oceanica & 1.57 & $3 \mathrm{H}-1,52 / 3 \mathrm{H}-1,90-91$ & $16.31 / 16.67$ \\
\hline CN13b & & 11. FAD Gephyrocapsa caribbeanica & 1.66 & $3 \mathrm{H}-1,52 / 3 \mathrm{H}-1,90-91$ & $16.31 / 16.67$ \\
\hline CN12d & NN18 & 12. LAD Discoaster brouweri & 1.89 & $3 \mathrm{H}-3,14-15 / 3 \mathrm{H}-3,52$ & $18.85 / 19.22$ \\
\hline
\end{tabular}

A. amplificus and the FAD of $A$. primus, which were expected in Zone NN11, cannot be recognized in this area. The lowest occurrence of Amaurolithus was observed in Sample 130-806B-26H-CC, which lies in the middle part of Zone NN11. In Holes 804C and 805B, Discoaster neohamatus occurs continuously in and below the lower part of this zone, but it is not clearly noticeable in Hole 806B.

\section{NN10 Discoaster calcaris Zone (Datums 22-23)}

Hole 806B: 285.09-338.96 mbsf; Samples 130-806B-31H-3, 26-27 $\mathrm{cm}$, to $-36 \mathrm{X}-7,26-27 \mathrm{~cm}$

Hole 805B: 220.27-266.43 mbsf; Samples 130-805B-24H-4, 23-24 $\mathrm{cm}$, to $-29 \mathrm{X}-3,23-24 \mathrm{~cm}$

Hole 804C: $72.80-114.70$ mbsf; Samples $130-804 \mathrm{C}-8 \mathrm{H}-\mathrm{CC}$ to $-13 \mathrm{H}-$ $3,90-91 \mathrm{~cm}$

This zone is represented by the stratigraphic interval ranging from the FAD of Discoaster quinqueramus (Datum 21) down to the LAD of D. hamatus (Datum 23). Therefore, samples in this zone are characterized by the absence of $D$. quinqueramus and $D$. hamatus. In Hole 804C, however, Samples 130-804C-11H-CC, -12H-3, 90-91 $\mathrm{cm}$, and $-12 \mathrm{H}-\mathrm{CC}$ contain Discoaster hamatus. Therefore, it seems that the base of Zone NN10 must be placed between Samples 130$804 \mathrm{C}-11 \mathrm{H}-3,90-91 \mathrm{~cm}$, and $-11 \mathrm{H}-\mathrm{CC}$. However, I considered $D$. hamatus in these samples to be reworked because the number of its specimens is very limited and some of these samples also contain Discoaster exilis and forms similar to Discoaster deflandrei. As is evident from Figures 4 and 9, the similarity of the floral changes among these holes supports this conclusion.

It is noteworthy that the abundance of reticulofenestrid coccoliths drastically decreases in the upper part of this zone. Finally, they become almost barren in Samples 130-806B-33H-CC and 130-805B$26 \mathrm{H}-\mathrm{CC}$, which are in the middle of Zone NN10. On the other hand, in Hole 804C Reticulofenestra are very rare in Sample 130-804C$10 \mathrm{H}-\mathrm{CC}$. Therefore, this sample may be placed in the middle of Zone NN10. In contrast to Reticulofenestra, sphenoliths are very abundant at this horizon. In particular, Samples 130-806B-32H-4, 26-27 cm, and $-33 \mathrm{H}-4,26-27 \mathrm{~cm}$, Samples 130-805B-25H-CC, -26H-4, 23-24 $\mathrm{cm}$, and $-27 \mathrm{H}-4,23-24 \mathrm{~cm}$, and Sample 130-804C-9H-3, 90-91 cm, are characterized by bloomlike abundances of tiny specimens of Sphenolithus abies. The most striking changes in the calcareous nannofossil assemblages in Cenozoic sequences on the Ontong Java Plateau can be recognized in Samples 130-806B-34H-4, 26-27 cm, $130-805 \mathrm{~B}-27 \mathrm{H}-4,23-24 \mathrm{~cm}$, and $130-804 \mathrm{C}-11 \mathrm{H}-3,90-91 \mathrm{~cm}$, in which Reticulofenestra again increases in the number of specimens (particularly very large-sized Reticulofenestra specimens) toward the bottom of these holes. In other words, only the lower part of Zone NN10 contains very large-sized ( $>7 \mu \mathrm{m}$ in diameter of coccolith) Reticulofenestra specimens. This dramatic event in the size change of Reticulofenestra coccoliths takes place in the middle part of Zone NN10 not only in Holes 806B and 805B but also in Hole 804C. Coccolithus pelagicus is comparatively abundant in this zone. In addition, Coccolithus miopelagicus is present almost consistently in and below this zone, although its sporadic occurrences are recognized above this zone in Holes $805 \mathrm{~B}$ and $804 \mathrm{C}$ (Fig. 5).

NN9 Discoaster hamatus Zone (Datums 23-26)

Hole 806B: 339.34-366.56 mbsf; Samples 130-806B-36X-CC to $-39 \mathrm{X}-6,26-27 \mathrm{~cm}$

Hole 805B: 267.93-282.73 mbsf; Samples 130-805B-29X-4, 23-24 $\mathrm{cm}$, to $-31 \mathrm{X}-1,23-24 \mathrm{~cm}$

Hole 804C: $120.30-149.70$ mbsf; Samples $130-804 \mathrm{C}-13 \mathrm{H}-\mathrm{CC}$ to $-17 \mathrm{X}-1,90-91 \mathrm{~cm}$

The samples mentioned above are characterized by continuous occurrences of Discoaster hamatus, whose total range defines Zone NN9 (between Datums 23 LAD D. hamatus and 26 FAD D. hamatus). In this zone, sphenoliths decrease in the number of their specimens and reticulofenestrid coccoliths become dominant again (Figs. 8 and 9). In this zone, Datums 24 (LAD Catinaster spp.) and 25 (FAD Catinaster calyculus) are easily detected. For example, Catinaster spp. is found below Sample 130-806B-37X-CC, and C. calyculus occurs only in Samples 130-806B$37 \mathrm{X}-\mathrm{CC}$ through $-39 \mathrm{X}-3,26-27 \mathrm{~cm}$. Therefore, Datums 24 and 25 are 
Table 5. Quaternary calcareous nannofossil datums, Hole 805C.

\begin{tabular}{|c|c|c|c|c|c|}
\hline \multicolumn{2}{|c|}{ Zone } & Species & $\begin{array}{l}\text { Age } \\
\text { (Ma) }\end{array}$ & Core, section, & Depth (mbsf) \\
\hline CN15 & NN21 & 1. FAD Emiliania huxleyi & 0.28 & $1 \mathrm{H}-2,23-24 / 1 \mathrm{H}-2,123-124$ & $1.73 / 2.73$ \\
\hline CN14b & NN20 & 2. LAD Pseudoemiliania lacunosa & 0.46 & $1 \mathrm{H}-5,23-24 / 1 \mathrm{H}-5,123-124$ & $6.23 / 7.23$ \\
\hline \multirow{8}{*}{ CN14a } & \multirow{10}{*}{ NN19 } & 3. LAD Reticulofenestra asanoi & 0.83 & $2 \mathrm{H}-5,23-24 / 2 \mathrm{H}-5,123-124$ & $13.79 / 14.75$ \\
\hline & & 4. FAD Gephyrocapsa parallela. & 0.90 & $2 \mathrm{H}-7,23-24 / 2 \mathrm{H}-\mathrm{CC}$ & $16.68 / 17.30$ \\
\hline & & 5. FAD Reticulofenestra asanoi & 1.06 & $3 \mathrm{H}-1,123-124 / 3 \mathrm{H}-2,23-24$ & $18.53 / 19.03$ \\
\hline & & 6. LAD LargeGephyrocapsa & 1.10 & $3 \mathrm{H}-2,23-24 / 3 \mathrm{H}-2,123-124$ & $19.03 / 20.03$ \\
\hline & & 7. LAD Helicosphaera sellii & 1.19 & $3 \mathrm{H}-5,23-24 / 3 \mathrm{H}-5,123-124$ & $23.53 / 24.53$ \\
\hline & & 8. FAD LargeGephyrocapsa & 1.36 & $3 \mathrm{H}-5,123-124 / 3 \mathrm{H}-6,23-24$ & $24.53 / 25.03$ \\
\hline & & 9. LAD Calcidiscus macintyrei & 1.45 & $3 \mathrm{H}-5,123-124 / 3 \mathrm{H}-6,23-24$ & $24.53 / 25.03$ \\
\hline & & 10. FAD Gephyrocapsa oceanica & 1.57 & $3 \mathrm{H}-6,23-24 / 3 \mathrm{H}-6,123-124$ & $25.03 / 26.03$ \\
\hline CN13b & & 11. FAD Gephyrocapsa caribbeanica & 1.66 & $3 \mathrm{H}-\mathrm{CC} / 4 \mathrm{H}-1,23-24$ & $26.70 / 27.02$ \\
\hline CN13a & & 12. LAD Discoaster brouweri & 1.89 & $4 \mathrm{H}-5,23-24 / 4 \mathrm{H}-6,23-24$ & $32.74 / 34.18$ \\
\hline
\end{tabular}

placed above Sample 130-806B-37X-CC and below Sample 130806B-39X-3, 26-27 cm. In comparison with these datums, the FAD of Discoaster neohamatus is not clear. In Hole 804C, D. neohamatus is found in the upper four samples of this zone, and the FAD of $D$. neohamatus is most probably placed between Samples 130-804C$15 \mathrm{X}-2,90-91 \mathrm{~cm}$, and $-15 \mathrm{X}-\mathrm{CC}$. In Hole 806B, however, D. neohamatus is found only in Sample 130-806B-36X-CC, which is the uppermost sample in Zone NN9. In Hole 805B, this datum looks like it can be placed in Zone NN10 between Samples 130-805B-28H-4, $23-24 \mathrm{~cm}$, and $-28 \mathrm{H}-\mathrm{CC}$. The large-sized specimen of a typical Calcidiscus macintyrei was found only in the upper part of this zone (e.g., above Sample 130-806B-37X-CC).

NN8 Catinaster coalitus Zone (Datums 26-27)

Hole 806B: 367.53-374.76 mbsf; Samples 130-806B-39X-CC to $-40 \mathrm{X}-5,26-27 \mathrm{~cm}$

Hole 805B: 284.23-285.73 mbsf; Samples 130-805B-31X-2, 23-24 $\mathrm{cm}$, to $-31 \mathrm{X}-3,23-24 \mathrm{~cm}$

Hole 804C: 151.20 mbsf; Sample 130-804C-17X-2, 90-91 cm

This zone is characterized by the presence of Catinaster coalitus and the absence of Discoaster hamatus (between Datums 26 FAD D. hamatus and $27 \mathrm{FAD}$ C. coalitus), and it is a very thin zone in all holes. In this zone, only three samples from Hole 806B and two samples from Hole $805 \mathrm{~B}$ were examined; no sample was available from Hole $804 \mathrm{C}$ for the present faunal analysis.

NN7 Discoaster kugleri Zone-NN6 Discoaster exilis Zone

(Datums 27-30)

Hole 806B: $375.96-472.03$ mbsf; Samples 130-806B-40X-CC to $-50 \mathrm{X}-\mathrm{CC}$

Hole 805B: 287.23-325.23 mbsf; Samples 130-805B-31X-4, 23-24 $\mathrm{cm}$, to $-35 \mathrm{X}-4,23-24 \mathrm{~cm}$

Hole 804C: 152.70-176.30 mbsf; Samples 130-804C-17X-3, 90-91 $\mathrm{cm}$, to $-19 \mathrm{X}-\mathrm{CC}$
The NN7/NN6 boundary is defined by the FAD of Discoaster kugleri. Typical specimens of this species were recognized in Samples 130-806B-43X-4, 26-27 cm, 130-805B-33X-CC, and 130-804C$18 \mathrm{X}-3,90-91 \mathrm{~cm}$. Therefore, these samples were assigned to Zone NN7. Except for these samples, however, the nominate species D. kugleri was almost absent throughout the interval. Therefore, I tentatively placed the samples mentioned above in the NN7-NN6 zonal interval (between Datums 27 FAD C. coalitus and 30 LAD Sphenolithus heteromorphus).

In the same manner as in the overlying zones, this zonal interval contains very dominant Reticulofenestra specimens (Fig. 9). Furthermore, Coccolithus pelagicus and its related forms are also comparatively abundant (Fig. 5).

In this NN7-NN6 interval, two important datums were easily recognized in the holes studied: Datums 28 (LAD Coronocyclus nitescens) and 29 (LAD Cyclicargolithus floridanus). In Hole 806B, Coronocyclus nitescens and Cyclicargolithus floridanus were continuously found below Samples 130-806B-45X-CC and -50X-3, 26-27 $\mathrm{cm}$, respectively. Therefore, Datums 28 and 29 were detected between Samples 130-806B-45X-3, 26-27 cm, and -45X-CC and between Samples 130-806B-49X-CC and 130-806B-50X-3, 26-27 cm, respectively. Similarly in Hole 805B, C. nitescens and C. floridanus occur continuously below Samples 130-805B-33X-CC and -34X-CC. On the other hand, although Datum 28 was placed between Samples 130-804C-18X-3, 90-91 cm, and -18X-CC, C. floridanus was not found throughout this interval, which suggests that the lower part of this zonal interval is missing.

Discoaster exilis occurs continuously throughout this interval, and Discoaster deflandrei was found in and below the lower part of this interval.

NN5 Sphenolithus heteromorphus Zone-NN4 Helicosphaera ampliaperta Zone (Datums 30-32)

Hole 806B: 473.56-579.30 mbsf; Samples 130-806B-51X-1, 26-27 $\mathrm{cm}$, to $-61 \mathrm{X}-\mathrm{CC}$ 
Table 6. Quaternary calcareous nannofossil datums, Hole 806B.

\begin{tabular}{|c|c|c|c|c|c|}
\hline \multicolumn{2}{|c|}{ Zone } & Species & $\begin{array}{l}\text { Age } \\
\text { (Ma) }\end{array}$ & $\begin{array}{l}\text { Core, section, } \\
\text { interval }(\mathrm{cm})\end{array}$ & Depth (mbsf) \\
\hline CN15 & NN21 & 1. FAD Emiliania huxleyi & 0.28 & $1 \mathrm{H}-3,32-33 / 1 \mathrm{H}-3,103-104$ & $3.32 / 4.03$ \\
\hline CN14b & NN20 & 2. LAD Pseudoemiliania lacunosa & 0.46 & $2 \mathrm{H}-2,26-27 / 2 \mathrm{H}-3,26-27$ & $8.20 / 9.65$ \\
\hline \multirow{8}{*}{ CN14a } & \multirow{10}{*}{ NN19 } & 3. LAD Reticulofenestra asanoi & 0.83 & $3 \mathrm{H}-2,26-27 / 3 \mathrm{H}-2,106-107$ & $17.67 / 18.43$ \\
\hline & & 4. FAD Gephyrocapsa parallela. & 0.90 & $3 \mathrm{H}-4,106-107 / 3 \mathrm{H}-5,26-27$ & $21.29 / 21.95$ \\
\hline & & 5. FAD Reticulofenestra asanoi & 1.06 & $3 \mathrm{H}-6,106-107 / 3 \mathrm{H}-7,26-27$ & $24.14 / 24.80$ \\
\hline & & 6. LAD LargeGephyrocapsa & 1.10 & $3 \mathrm{H}-\mathrm{CC} / 4 \mathrm{H}-1,107-108$ & $25.50 / 26.05$ \\
\hline & & 7. LAD Helicosphaera sellii & 1.19 & $4 \mathrm{H}-4,26-27 / 4 \mathrm{H}-4,107-108$ & $30.06 / 30.84$ \\
\hline & & 8. FAD Large Gephyrocapsa & 1.36 & $4 \mathrm{H}-5,26-27 / 4 \mathrm{H}-5,106-107$ & $31.50 / 32.26$ \\
\hline & & 9. LAD Calcidiscus macintyrei & 1.45 & $4 \mathrm{H}-6,106-107 / 4 \mathrm{H}-7,26-27$ & $33.70 / 34.37$ \\
\hline & & 10. FAD Gephyrocapsa oceanica & 1.57 & $4 \mathrm{H}-7,66-67 / 4 \mathrm{H}-\mathrm{CC}$ & $34.75 / 35.00$ \\
\hline CN13b & & 11. FAD Gephyrocapsa caribbeanica & 1.66 & $4 \mathrm{H}-\mathrm{CC} / 5 \mathrm{H}-1,26-27$ & $35.00 / 35.25$ \\
\hline CN12d & & 12. LAD Discoaster brouweri & 1.89 & $5 \mathrm{H}-6,26-27 / 5 \mathrm{H}-7,26-27$ & $42.39 / 43.81$ \\
\hline
\end{tabular}

Hole 805B: 326.73-389.75 mbsf; Samples 130-805B-35X-5, 23-24 $\mathrm{cm}$, to $-42 \mathrm{X}-2,25-26 \mathrm{~cm}$

Hole 804C: 178.60-206.16 mbsf; Samples 130-804C-20X-1, 90-91 $\mathrm{cm}$, to $-22 \mathrm{X}-\mathrm{CC}$

The boundary between Zones NN6 and NN5 was easily detected by the LAD of Sphenolithus heteromorphus (Datum 30). Helicosphaera ampliaperta, whose last occurrence defines the top of Zone NN4, has not been found in any of the Leg 130 samples taken from the pertinent stratigraphic interval and must have been ecologically excluded from this region. It follows that the combination of Zones NN5 and NN4 results in a long biostratigraphic interval that straddles the lower/middle Miocene boundary. Therefore, I am forced to place the above-mentioned samples in the NN5-NN4 zonal interval (between Datums 30 LAD S. heteromorphus and $32 \mathrm{LAD}$ $S$. belemnos).

Throughout this interval, Coccolithus pelagicus and C. miopelagicus are relatively abundant (Fig. 5). In Holes $806 \mathrm{~B}$ and 805B, the upper part of this interval still contains abundant reticulofenestrid coccoliths. In addition, Cyclicargolithus floridanus becomes dominant, although the number of specimens decreases temporarily in the middle of this interval (Fig. 6).

Compared with the upper part of this interval, the flora in the lower part is more diversified. The main reason for this is the abrupt decrease in Reticulofenestra spp. As in Zone NN10, reticulofenestrid coccoliths are rare in the lower part of the NN5/NN4 zonal interval (Fig. 9). For example, Reticulofenestra spp. below Sample 130-806B-57X4, 26-27 cm, in Hole 806B are rare; it is almost barren in Samples 130-806B-57X-4, 26-27 cm, -59X-4, 26-27 cm, and -60X-3, 26-27 $\mathrm{cm}$. Similarly, Reticulofenestra spp. below Sample 130-805B-40X$\mathrm{CC}$ in Hole $805 \mathrm{~B}$ are rare. On the other hand, all samples belonging to this NN5-NN4 zonal interval from Hole 804C (except for uppermost Sample 130-804C-20X-3, 90-91 cm) contain a small number of specimens of reticulofenestrid coccoliths (Fig. 9C).

Sphenolithus heteromorphus occurs continuously down to Sample 130-806B-61X-4, 26-27 cm. Consequently, Datum 31 (FAD $S$. heteromorphus) was placed between Samples 130-806B-61X-4,
26-27 cm, and $-61 \mathrm{X}-\mathrm{CC}$, which is slightly above the NN4/NN3 boundary. In Hole $805 \mathrm{~B}$, this datum corresponds with the NN4/NN3 boundary. In Hole 804C, a few specimens of Sphenolithus belemnos were found in Samples 130-804C-22X-2, 90-91 cm, and -22X-3, 90-91 cm. However, they occur together with $S$. heteromorphus. Therefore, I consider $S$. belemnos as reworked. Sphenolithus spp. is not bloomlike as in Zone NN10, but it is fairly abundant (Fig. 8).

Discoasters are also abundant throughout, although their relative abundances vary from horizon to horizon (Fig. 7). Most of them are Discoaster deflandrei, D. exilis, and D. variabilis. In addition to these species, many asteroliths are lumped under Discoaster spp. because these specimens cannot be identified at the species level by reason of their severe dissolution and/or secondary overgrowth with primary features largely destroyed. Bukry's (1973) end-of-acme concept of Discoaster deflandrei, which was quantified and redefined by Rio et al. (1990) recently as the decrease to $<30 \%$ of $D$. deflandrei of the total discoaster assemblage, allows splitting of the NN5/NN4 zonal interval into two parts of approximately equal duration. In Holes 806B and 805B, Discoaster deflandrei is common in the lower part of this interval. For example, in Hole $806 \mathrm{~B}$, this species is dominant below Sample 130-806B-53X-CC. Therefore, the top of acme (TA) of Discoaster deflandrei seems to be placed between Samples 130-806B-53X-2, 26-27 cm, and -53X-CC. In Hole 805B, however, the TA of the Discoaster deflandrei group is not so clear as in Hole $806 \mathrm{~B}$. In Hole $804 \mathrm{C}$, all samples that belong to this interval contain fairly abundant $D$. deflandre $i$, and these samples are most probably assigned to the lower part of this interval. Based on the floral changes mentioned above, I conclude that the upper part of the NN5-NN4 zonal interval in Hole 804C is missing.

\section{NN3 Sphenolithus belemnos Zone (Datums 32-33)}

Hole 806B: 579.56-588.56 mbsf; Samples 130-806B-62X-1, 26-27 $\mathrm{cm}$, to $-62 \mathrm{X}-7,26-27 \mathrm{~cm}$

Hole $805 \mathrm{~B}$ : very thin or missing

Hole 804C: very thin or missing 
Table 7. Quaternary calcareous nannofossil datums, Hole 807A.

\begin{tabular}{|c|c|c|c|c|c|}
\hline \multicolumn{2}{|c|}{ Zone } & Species & $\begin{array}{l}\text { Age } \\
\text { (Ma) }\end{array}$ & $\begin{array}{l}\text { Core, section, } \\
\text { interval }(\mathrm{cm})\end{array}$ & Depth (mbsf) \\
\hline CN15 & NN21 & 1. FAD Emiliania huxleyi & 0.28 & $1 \mathrm{H}-4,8-10 / 1 \mathrm{H}-4,18-20$ & $4.58 / 4.68$ \\
\hline CN14b & NN20 & 2. LAD Pseudoemiliania lacunosa & 0.46 & $1 \mathrm{H}-\mathrm{CC}, 8-10 / 1 \mathrm{H}-\mathrm{CC}$ & $7.28 / 7.37$ \\
\hline \multirow{8}{*}{ CN14a } & \multirow{9}{*}{ NN19 } & 3. LAD Reticulofenestra asanoi & 0.83 & $2 \mathrm{H}-5,24-25 / 2 \mathrm{H}-5,104-105$ & $13.39 / 14.16$ \\
\hline & & 4. FAD Gephyrocapsa parallela. & 0.90 & $2 \mathrm{H}-6,104-105 / 2 \mathrm{H}-7,24-25$ & $15.60 / 16.27$ \\
\hline & & 5. FAD Reticulofenestra asanoi & 1.06 & $3 \mathrm{H}-1,104-105 / 3 \mathrm{H}-2,24-25$ & $17.90 / 18.57$ \\
\hline & & 6. LAD LargeGephyrocapsa & 1.10 & $3 \mathrm{H}-2,24-25 / 3 \mathrm{H}-2,104-105$ & $18.57 / 19.34$ \\
\hline & & 7. LAD Helicosphaera sellii & 1.19 & $3 \mathrm{H}-5,24-25 / 3 \mathrm{H}-5,104-105$ & $22.88 / 23.65$ \\
\hline & & 8. FAD Large Gephyrocapsa & 1.36 & $3 \mathrm{H}-6,24-25 / 3 \mathrm{H}-6,104-105$ & $24.32 / 25.09$ \\
\hline & & 9. LAD Calcidiscus macintyrei & 1.45 & $3 \mathrm{H}-7,24-25 / 3 \mathrm{H}-\mathrm{CC}$ & $25.76 / 26.40$ \\
\hline & & 10. FAD Gephyrocapsa oceanica & 1.57 & $3 \mathrm{H}-7,24-25 / 3 \mathrm{H}-\mathrm{CC}$ & $25.76 / 26.40$ \\
\hline CN13b & & 11. FAD Gephyrocapsa caribbeanica & 1.66 & $3 \mathrm{H}-\mathrm{CC} / 4 \mathrm{H}-1,24-25$ & $26.40 / 26.24$ \\
\hline CN13a & NN18 & 12. LAD Discoaster brouweri & 1.89 & $4 \mathrm{H}-4,104-105 / 4 \mathrm{H}-5,24-25$ & $31.70 / 32.37$ \\
\hline
\end{tabular}

This zone was recognized by the presence of Sphenolithus belemnos and the absence of Triquetrorhabdulus carinatus. In Hole 806B, the interval assigned to this zone (between Datums 32 LAD $S$. belemnos and 33 LAD T. carinatus) is thin, only about $9 \mathrm{~m}$ in thickness. The flora of only one sample from this hole (Sample $130-806 \mathrm{~B}-62 \mathrm{X}-4,26-27 \mathrm{~cm}$ ) was examined. This flora is characterized by the occurrence of Sphenolithus belemnos together with abundant Coccolithus pelagicus, Cyclicargolithus floridanus, Discoaster deflandrei, and Sphenolithus moriformis. In Holes $804 \mathrm{C}$ and $805 \mathrm{~B}$, this zone is very thin or missing; an early Miocene hiatus is probably inferred at Sites 805 and 804.

\section{NN2 Discoaster druggii Zone (Datums 33-35)}

Hole 806B: $589.00-627.50$ mbsf; Samples 130-806B-62X-CC to $-66 \mathrm{X}-\mathrm{CC}$

Hole 805B: 391.23-426.73 mbsf; Samples 130-805B-42X-3, 23-24 $\mathrm{cm}$, to $-46 \mathrm{X}-1,23-24 \mathrm{~cm}$

Hole 804C: 207.70-249.30 mbsf; Samples 130-804C-23X-1, 90-91 $\mathrm{cm}$, to $-27 \mathrm{X}-3,90-91 \mathrm{~cm}$

This zone is defined by the co-occurrence of Triquetrorhabdulus carinatus and Discoaster druggii (between Datums 33 LAD T. carinatus and 35 FAD D. druggii). However, in the holes studied, $D$. druggii was very rare and occurred sporadically throughout this zone. Therefore, it was very difficult to detect the base of this zone (Datum 35 ). In this investigation, I tentatively placed the NN2/NN1 boundary just below the deepest sample in which $\mathrm{I}$ found $D$. druggii in each hole. As is evident in Figure $4 \mathrm{C}$, this zone of Hole $804 \mathrm{C}$ is summarized as follows: In the upper part of this zone, Reticulofenestra spp. becomes dominant again and Cyclicargolithus floridanus becomes rare. In the lower part of this zone, Reticulofenestra spp. decreases in the number of its specimens drastically and $C$. floridanus abruptly becomes dominant again.

On the other hand, in Holes 806B and 805B, Reticulofenestra spp. is rather dominant throughout this zone. Furthermore, it is continuously abundant down to the upper part of underlying Zone NN1 (Figs. $4 \mathrm{~A}$ and $4 \mathrm{~B}$ ). Therefore, it is quite within the bounds of possibility that the NN2/NN1 boundary (Datum 35) in Holes 806B and 805B can be placed at deeper levels in these holes. Samples 130-806B-62X-CC through -64X-1, 43-44 cm, contain Sphenolithus belemnos; therefore, these four samples belong to the interval between Datums 33 (LAD Triquetrorhabdulus carinatus) and 34 (FAD Sphenolithus belemnos). Datum 34 in Hole 805B was placed between Samples $130-805 \mathrm{~B}-43 \mathrm{X}-3,23-24 \mathrm{~cm}$, and $-43 \mathrm{X}-\mathrm{CC}$. As is obvious from Table 9, sediments in Hole $804 \mathrm{C}$ that correspond to the interval between these two datums are very thin. Triquetrorhabdulus carinatus occurs continuously throughout this zone in each hole; in particular, it is rather abundant in Hole 804C. Sporadic occurrences of this species in the overlying zones are considered to be reworked. It is noteworthy that samples below Datum 34 contain Sphenolithus dissimilis.

\section{NN1 Triquetrorhabdulus carinatus Zone (below Datum 35)}

Hole 806B: below 627.76 mbsf; below Sample 130-806B-67X-1, $26-27 \mathrm{~cm}$

Hole 805B: below 428.23 mbsf; below Sample 130-805B-46X-2, $23-24 \mathrm{~cm}$

Hole 804C: 250.80-253.98 mbsf; Samples 130-804C-27X-4, 90-91 $\mathrm{cm}$, to $-27 \mathrm{X}-\mathrm{CC}$

The samples mentioned above contain neither Discoaster druggii nor Sphenolithus ciperoensis and are assigned to early Miocene Zone NN1 (below Datum 35 FAD D. druggii). As mentioned above, however, the NN2/NN1 boundary (Datum 35) is tentative. The absence of $D$. druggii in these sequences does not necessarily imply a position within Zone NN1 because of the problem of calcite overgrowth. The nannofossils in this zone are abundant but moderate to poorly preserved, monotonous assemblages composed mainly of abundant Discoaster deflandrei, Cyclicargolithus floridanus, and Sphenolithus moriformis. It is noteworthy, in particular, that Cyclicargolithus floridanus among these species is fairly abundant in the lower part of this zone in Holes 805B and $806 \mathrm{~B}$, whereas in Hole $804 \mathrm{C}$ this species is rich in the lower part of Zone NN2 (Fig. 6). It seems most probable that the NN2/NN1 boundary (Datum 35) in Holes $806 \mathrm{~B}$ and $805 \mathrm{~B}$ must 
Table 8. Neogene calcareous nannofossil datums, Hole 803D.

\begin{tabular}{|c|c|c|c|c|c|}
\hline \multicolumn{2}{|c|}{ Zone } & Species & Age & $\begin{array}{l}\text { Core, section, } \\
\text { interval }(\mathrm{cm})\end{array}$ & Depth (mbsf) \\
\hline CN13a & NN19 & 12. LAD Discoaster brouweri & 1.89 & $3 \mathrm{H}-4,15-16 / 3 \mathrm{H}-4,90-91$ & $16.49 / 17.21$ \\
\hline CN12d & NN18 & 13. LAD Discoaster pentaradiatus & 2.35 & $4 \mathrm{H}-2,15-16 / 4 \mathrm{H}-3.15-16$ & $23.07 / 24.49$ \\
\hline \multirow{2}{*}{ CN12C } & \multirow[t]{2}{*}{ NN17 } & 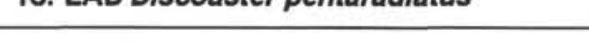 & 2.00 & 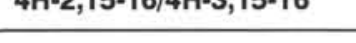 & $20.01 / 24.49$ \\
\hline & & 14. LAD Discoaster surculus & 2.41 & $4 \mathrm{H}-4,15-16 / 4 \mathrm{H}-5,15-16$ & $25.92 / 27.34$ \\
\hline $\begin{array}{l}\text { CN12b } \\
\text { CN12a }\end{array}$ & \multirow[t]{2}{*}{ NN16 } & 15. LAD Sphenolithus spp. & 3.45 & $6 \mathrm{H}-2,15-16 / 6 \mathrm{H}-3,15-16$ & $41.44 / 42.29$ \\
\hline \multirow{2}{*}{$\begin{array}{l}\text { CN11b } \\
\text { CN11a }\end{array}$} & & 16. LAD Reticulofenestra pseudoumbilica & 3.56 & $6 \mathrm{H}-4,15-16,6 \mathrm{H}-5,15-16$ & $43.14 / 43.99$ \\
\hline & $\begin{array}{l}\text { NN15 } \\
\text { NN13 }\end{array}$ & 17. FAD Ceratolithus rugosus & 4.6 & $7 \mathrm{H}-\mathrm{CC} / 8 \mathrm{H}-2,15-16$ & $55.60 / 56.71$ \\
\hline \multirow{2}{*}{ CN10b } & \multirow{4}{*}{ NN12 } & 18. LAD Ceratolithus acutus & 4.6 & $8 \mathrm{H}-2,15-16 / 8 \mathrm{H}-3,15-16$ & $57.18 / 58.61$ \\
\hline & & 19. FAD Ceratolithus acutus & 4.9 & $8 \mathrm{H}-\mathrm{CC} / 9 \mathrm{H}-1,15-16$ & $65.10 / 65.25$ \\
\hline \multirow{2}{*}{ CN10a } & & 20. LAD Triquetrorhabdulus rugosus & 4.9 & $8 \mathrm{H}-\mathrm{CC} / 9 \mathrm{H}-1,15-16$ & $65.10 / 65.25$ \\
\hline & & 21. LAD Discoaster quinqueramus & 5.0 & $9 \mathrm{H}-1,15-16 / 9 \mathrm{H}-2,15-16$ & $65.25 / 66.70$ \\
\hline \multirow{2}{*}{$\begin{array}{l}\text { CN9b } \\
\text { CN8a }\end{array}$} & NN11 & 22. FAD Discoaster quinqueramus & 7.5 & $16 \mathrm{H}-4,15-16 / 16 \mathrm{H}-5,15-16$ & $136.22 / 137.70$ \\
\hline & NN10 & 23. LAD Discoaster hamatus & 8.7 & $19 \mathrm{H}-\mathrm{CC} / 20 \mathrm{H}-1,15-16$ & $169.60 / 169.74$ \\
\hline \multirow[t]{2}{*}{ CN7b } & \multirow{3}{*}{ NN9 } & 24. LAD Catinaster spp. & 8.8 & $20 \mathrm{H}-1,15-16 / 20 \mathrm{H}-2,15-16$ & 169.74/171.17 \\
\hline & & 25. FAD Catinaster calyculus & 10.0 & $21 \mathrm{H}-3,15-16 / 21 \mathrm{H}-4,15-16$ & $182.07 / 183.49$ \\
\hline CN7a & & 26. FAD Discoaster hamatus & 10.5 & $21 H-6,15-16 / 21 H-7,15-16$ & $186.32 / 187.74$ \\
\hline CN6 & NN8 & 27. FAD Catinaster coalitus & 11.1 & $21 H-6,15-16 / 21 H-7,15-16$ & $186.32 / 187.74$ \\
\hline \multirow[t]{2}{*}{ CN5b } & \multirow{3}{*}{$\begin{array}{l}\text { NN7 } \\
\text { NN6 }\end{array}$} & 28. LAD Coronocyclus nitescens & 12.8 & $22 \mathrm{H}-\mathrm{CC} / 23 \mathrm{H}-1,15-16$ & $198.10 / 198.24$ \\
\hline & & 29. LAD Cyclicargolithus floridanus & 13.1 & $24 \mathrm{H}-6,15-16 / 24 \mathrm{H}-7,15-16$ & $214.87 / 216.30$ \\
\hline CN5a & & 30. LAD Sphenolithus heteromorphus & 13.6 & $25 X-2,15-16 / 25 X-3,15-16$ & $218.75 / 220.25$ \\
\hline CN3 & \multirow[t]{2}{*}{$\begin{array}{l}\text { NN5 } \\
\text { NN4 }\end{array}$} & 31. FAD Sphenolithus heteromorphus & 18.6 & $28 \mathrm{X}-1,12-13 / 28 \mathrm{X}-2,15-16$ & $246.02 / 247.55$ \\
\hline \multirow{3}{*}{ CN2 } & & 32. LAD Sphenolithus belemnos & 18.8 & $28 X-1,12-13 / 28 X-2,15-16$ & $246.02 / 247.55$ \\
\hline & NN3 & 33. LAD Triquetrorhabdulus carinatus & 19.5 & $28 X-1,12-13 / 28 X-2,15-16$ & $246.02 / 247.55$ \\
\hline & \multirow[t]{2}{*}{ NN2 } & 34. FAD Sphenolithus belemnos & 20.0 & $28 X-C C / 29 X-1,15-16$ & $252.80 / 255.65$ \\
\hline CN1c & & 35. FAD Discoaster druggii & 23.6 & $35 X-3,13-14 / 35 X-4,14-15$ & $316.13 / 317.64$ \\
\hline
\end{tabular}

be at deeper horizons. In Hole $804 \mathrm{C}$, the two deepest samples (Samples $130-804 \mathrm{C}-28 \mathrm{X}-3,86-87 \mathrm{~cm}$, and $-28 \mathrm{X}-\mathrm{CC}$ ) were assigned to the Oligocene because of the occurrence of Sphenolithus ciperoensis. Therefore, the Oligocene/Miocene boundary can be placed in the upper part of Core 130-804C-28X.

\section{SIZE VARIATION OF RETICULOFENESTRA COCCOLITH}

Observation

The genus Reticulofenestra is an elliptical placolith constructed of elements that are not imbricate or only slightly so, with a central area that is either open or spanned by many small laths that may form a reticulum. Therefore, this genus is recognized by its rim structure and central area.
Reticulofenestra specimens occur in Eocene through Holocene sediments and dominate coccolith assemblages in the Neogene. These Neogene reticulofenestrid specimens have, however, no characteristic structures except for the size of the placolith diameter and the size of the central opening. Consequently, the nomenclatural taxonomy of Reticulofenestra is extremely confused. This serious problem has been discussed by Backman (1980), Pujos (1987), Driever (1988), Gallagher (1989), Young (1990), and others. In the present investigation, these reticulofenestrid coccoliths are identified tentatively to $R$. gelida, $R$. haqii, $R$. minuta, $R$. minutula, $R$. pseudoumbilica, and others mainly based on Young's (1990) taxonomic concept.

In 1990, Reticulofenestra size variations in the Neogene deep-sea sediments of the western Indian Ocean and the Red Sea were systematically observed by Young. He presented a surprisingly simple, consistent, and biostratigraphically useful pattern for the size vari- 
Table 9. Neogene calcareous nannofossil datums, Hole 804C.

\begin{tabular}{|c|c|c|c|c|c|}
\hline \multicolumn{2}{|c|}{ Zone } & Species & Age & Core, section, & Depth (mbsf) \\
\hline CN13a & NN19 & 12. LAD Discoaster brouweri & 1.89 & $3 \mathrm{H}-3,14-15 / 3 \mathrm{H}-3,52$ & $18.85 / 19.22$ \\
\hline CN12d & NN18 & \multirow{2}{*}{ 13. LAD Discoaster pentaradiatus } & \multirow[b]{2}{*}{2.35} & \multirow[b]{2}{*}{$3 \mathrm{H}-\mathrm{CC} / 4 \mathrm{H}-3,90-91$} & \multirow[b]{2}{*}{$25.30 / 29.01$} \\
\hline \multirow{2}{*}{ CN12c } & \multirow{2}{*}{ NN17 } & & & & \\
\hline & & 14. LAD Discoaster surculus & 2.41 & $4 \mathrm{H}-3,90-91 / 4 \mathrm{H}-4,90-91$ & $29.01 / 30.44$ \\
\hline CN12a & NN16 & 15. LAD Sphenolithus spp. & 3.45 & $4 \mathrm{H}-\mathrm{CC} / 5 \mathrm{H}-4,90-91$ & $34.80 / 39.48$ \\
\hline \multirow{2}{*}{$\begin{array}{l}\text { CN11b } \\
\text { CN11a }\end{array}$} & \multirow{2}{*}{$\begin{array}{l}\text { NN15 } \\
\text { NN13 }\end{array}$} & 16. LAD Reticulofenestra pseudoumbilica & 3.56 & $4 \mathrm{H}-\mathrm{CC} / 5 \mathrm{H}-4,90-91$ & $34.80 / 39.48$ \\
\hline & & 17. FAD Ceratolithus rugosus & 4.6 & $5 \mathrm{H}-\mathrm{CC} / 6 \mathrm{H}-1,90-91$ & $44.30 / 44.63$ \\
\hline \multirow{2}{*}{ CN10b } & \multirow{4}{*}{ NN12 } & 18. LAD Ceratolithus acutus & 4.6 & not recognized & \\
\hline & & 19. FAD Ceratolithus acutus & 4.9 & not recognized & \\
\hline \multirow{2}{*}{ CN10a } & & 20. LAD Triquetrorhabdulus rugosus & 4.9 & $5 \mathrm{H}-\mathrm{CC} / 6 \mathrm{H}-1,90-91$ & $44.30 / 44.63$ \\
\hline & & 21. LAD Discoaster quinqueramus & 5.0 & $5 \mathrm{H}-\mathrm{CC} / 6 \mathrm{H}-1,90-91$ & $44.30 / 44.63$ \\
\hline \multirow{2}{*}{$\begin{array}{l}\text { CN9b } \\
\text { CN8a }\end{array}$} & NN11 & 22. FAD Discoaster quinqueramus & 7.5 & $8 \mathrm{H}-6,90-91 / 8 \mathrm{H}-\mathrm{CC}$ & $71.45 / 72.80$ \\
\hline & NN10 & 23. LAD Discoaster hamatus & 8.7 & $13 \mathrm{H}-3,90-91 / 13 \mathrm{H}-\mathrm{CC}$ & $114.70 / 120.30$ \\
\hline \multirow[t]{2}{*}{ CN7b } & \multirow{3}{*}{ NN9 } & 24. LAD Catinaster spp. & 8.8 & $13 \mathrm{H}-3,90-91 / 13 \mathrm{H}-\mathrm{CC}$ & $114.70 / 120.30$ \\
\hline & & 25. FAD Catinaster calyculus & 10.0 & $15 X-C C / 16 X-1,90-91$ & $134.55 / 140.20$ \\
\hline CN7a & & 26. FAD Discoaster hamatus & 10.5 & $17 X-1,90-91 / 17 X-2,90-91$ & $149.70 / 151.20$ \\
\hline CN6 & NN8 & 27. FAD Catinaster coalitus & 11.1 & $17 X-2,90-91 / 17 X-3,90-91$ & $151.20 / 152.70$ \\
\hline CN5b & NN7 & 28. LAD Coronocyclus nitescens & 12.8 & $18 X-4,90-91 / 18 X-5,90-91$ & $163.70 / 165.20$ \\
\hline & NN6 & 29. LAD Cyclicargolithus floridanus & 13.1 & $19 X-6,56-57 / 19 X-C C$ & $176.06 / 176.30$ \\
\hline CN5a & & 30. LAD Sphenolithus heteromorphus & 13.6 & $19 X-C C / 20 X-1,90-91$ & $176.30 / 178.60$ \\
\hline $\begin{array}{l}\text { CN4 } \\
\text { CN3 }\end{array}$ & NN5 & 31. FAD Sphenolithus heteromorphus & 18.6 & $22 X-C C / 23 X-1,90-91$ & 206.16/207.70 \\
\hline & & 32. LAD Sphenolithus belemnos & 18.8 & $22 X-C C / 23 X-1,90-91$ & $206.16 / 207.70$ \\
\hline CN2 & NN3 & 33. LAD Triquetrorhabdulus carinatus & 19.5 & $22 X-C C / 23 X-1,90-91$ & $206.16 / 207.70$ \\
\hline & NN2 & 34. FAD Sphenolithus belemnos & 20.0 & $23 X-1,90-91 / 23 X-2,90-91$ & $207.70 / 209.20$ \\
\hline $\begin{array}{l}\text { CN1c } \\
\text { CN1b }\end{array}$ & NN1 & 35. FAD Discoaster druggii & 23.6 & $27 X-3,90-91 / 27 X-4,90-91$ & $249.30 / 250.80$ \\
\hline
\end{tabular}

ations of reticulofenestrid coccoliths. In the present investigation, I have made similar systematic observations on the size variations of reticulofenestrid coccoliths not only in the middle Miocene to Pliocene but also throughout the Miocene to Pliocene sequences at Sites 804,805 , and 806 on the Ontong Java Plateau.

The sizes of all reticulofenestrid coccoliths (except for Dictyococcites productus) encountered during counts of 200 calcareous nannofossil specimens in each sample were measured under an ordinary light microscope using an eyepiece graticule. After measurements were taken, all reticulofenestrid coccoliths were classified into the following four groups:

Very large reticulofenestrid coccoliths: larger than $7 \mu \mathrm{m}$

Large reticulofenestrid coccoliths: $7-5 \mu \mathrm{m}$
Small reticulofenestrid coccoliths: $5-3 \mu \mathrm{m}$

Very small reticulofenestrid coccoliths: smaller than $3 \mu \mathrm{m}$

The relative abundances of each group in Holes 806B, 805C, $805 \mathrm{~B}$, and $804 \mathrm{C}$ with geological ages are shown in Figure 9.

As is evident from this figure, roughly speaking, the relative abundance of reticulofenestrid coccoliths gradually decreases toward the bottom of each core. For example, in Hole 806B they form nearly $80 \%$ in the upper part of the hole, but only a few percent of the flora are present or are barren altogether at the base of the hole. The general decrease in the relative abundance is interrupted by remarkable and abrupt drops in abundances of reticulofenestrid coccoliths at two horizons. To state this differently, Reticulofenestra specimens are abundant in three stratigraphic intervals in the Pliocene-Miocene se- 
Table 10. Neogene calcareous nannofossil datums, Hole 805C.

\begin{tabular}{|c|c|c|c|c|c|}
\hline \multicolumn{2}{|c|}{ Zone } & Species & Age & $\begin{array}{l}\text { Core, section, } \\
\text { interval }(\mathrm{cm})\end{array}$ & Depth (mbsf) \\
\hline CN13a & NN19 & 12. LAD Discoaster brouweri & 1.89 & $4 \mathrm{H}-5,23-24 / 4 \mathrm{H}-6,23-24$ & $32.74 / 34.18$ \\
\hline CN12d & NN18 & 13. LAD Discoaster pentaradiatus & 2.35 & $5 \mathrm{H}-4,23-24 / 5 \mathrm{H}-5,23-24$ & $40.95 / 42.42$ \\
\hline CN12C & NN17 & 14. LAD Discoaster surculus & 2.41 & $5 \mathrm{H}-6,23-24 / 5 \mathrm{H}-\mathrm{CC}$ & $43.89 / 45.80$ \\
\hline $\begin{array}{l}\text { CN12b } \\
\text { CN12a }\end{array}$ & NN16 & 15. LAD Sphenolithus spp. & 3.45 & & \\
\hline \multirow{2}{*}{$\begin{array}{l}\text { CN11b } \\
\text { CN11a }\end{array}$} & \multirow{2}{*}{$\begin{array}{l}\text { NN15 } \\
\text { NN13 }\end{array}$} & 16. LAD Reticulofenestra pseudoumbilica & 3.56 & & \\
\hline & & 17. FAD Ceratolithus rugosus & 4.6 & & \\
\hline \multirow{2}{*}{ CN10b } & \multirow{4}{*}{ NN12 } & 18. LAD Ceratolithus acutus & 4.6 & & \\
\hline & & 19. FAD Ceratolithus acutus & 4.9 & & \\
\hline \multirow[t]{2}{*}{ CN10a } & & 20. LAD Triquetrorhabdulus rugosus & 4.9 & & \\
\hline & & 21. LAD Discoaster quinqueramus & 5.0 & & \\
\hline \multirow{2}{*}{$\begin{array}{l}\text { CN9b } \\
\text { CN8a }\end{array}$} & NN11 & 22. FAD Discoaster quinqueramus & 7.5 & & \\
\hline & NN10 & 23. LAD Discoaster hamatus & 8.7 & & \\
\hline \multirow{3}{*}{ CN7b } & \multirow{4}{*}{ NN9 } & & & & \\
\hline & & 24. LAD Catinaster spp. & 8.8 & & \\
\hline & & 25. FAD Catinaster calyculus & 10.0 & & \\
\hline CN7a & & 26. FAD Discoaster hamatus & 10.5 & & \\
\hline \multirow[t]{2}{*}{ CN6 } & NN8 & & & & \\
\hline & \multirow{4}{*}{$\begin{array}{l}\text { NN7 } \\
\text { NN6 }\end{array}$} & 27. FAD Catinaster coalitus & 11.1 & & \\
\hline \multirow[t]{2}{*}{ CN5b } & & 28. LAD Coronocyclus nitescens & 12.8 & & \\
\hline & & 29. LAD Cyclicargolithus floridanus & 13.1 & & \\
\hline CN5a & & 30. LAD Sphenolithus heteromorphus & 13.6 & & \\
\hline CN4 & \multirow{3}{*}{$\begin{array}{l}\text { NN5 } \\
\text { NN4 }\end{array}$} & 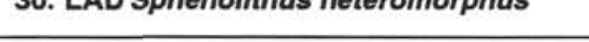 & 13.0 & & \\
\hline \multirow{4}{*}{ CN2 } & & 31. FAD Sphenolithus heteromorphus & 18.6 & & \\
\hline & & 32. LAD Sphenolithus belemnos & 18.8 & & \\
\hline & NN3 & 33. LAD Triquetrorhabdulus carinatus & 19.5 & & \\
\hline & \multirow[t]{2}{*}{ NN2 } & 34. FAD Sphenolithus belemnos & 20.0 & & \\
\hline CN1c & & & & & \\
\hline CN1b & NN1 & 35. FAD Discoaster druggii & 23.6 & & \\
\hline
\end{tabular}

quence. For convenience, I will designate these intervals as Intervals $\mathrm{A}, \mathrm{B}$, and $\mathrm{C}$, in descending order. The characteristics of these intervals in Holes $806 \mathrm{~B}, 805 \mathrm{C}$, and $805 \mathrm{~B}$ are as follows (Figs. 9 and 10):

Interval A: lowest NN19-middle NN10

Hole 806B: down to Sample 130-806B-32H-CC

Hole 805B: down to Sample 130-805B-25H-CC

In this interval the relative abundances of reticulofenestrid coccoliths gradually decrease downward. In Holes $806 \mathrm{~B}$ and 805B, its highest abundances are $88.5 \%$ (in Sample 130-806B-8H-CC) and $90 \%$ (in Sample 130-805C-6H-CC) of the total floras recognized in Zone NN16. This interval is particularly characterized by the abundant occurrence of very small Reticulofenestra $(<3 \mu \mathrm{m}$ in diameter).
Based on the relative abundances of these very small reticulofenestrid coccoliths, this interval has been subdivided into upper $\left(A_{1}\right)$ and lower $\left(A_{2}\right)$ intervals as follows:

Interval $\mathrm{A}_{1}$ : lowest NN19-upper NN12

Hole 806B: down to Sample 130-806B-15H-CC

Hole 805B: down to Sample 130-805B-12H-4, 23-24 cm

This interval is characterized by the consistently predominant occurrence of very small reticulofenestrid specimens. It accounts for consistently more than $24.5 \%$ of the total flora: its average relative abundances are $59.3 \%$ and $48.2 \%$ in Holes $806 \mathrm{~B}$ and $805 \mathrm{~B}$, respectively. Only in the lower part of Interval $A_{1}$ (below Samples 130$806 \mathrm{~B}-11 \mathrm{H}-4,26-27 \mathrm{~cm}$, and $130-805 \mathrm{~B}-9 \mathrm{H}-4,23-24 \mathrm{~cm}$ ), very large 
Table 11. Neogene calcareous nannofossil datums, Hole 805B.

\begin{tabular}{|c|c|c|c|c|c|}
\hline \multicolumn{2}{|c|}{ Zone } & Species & Age & Core, section, & Depth (mbsf) \\
\hline CN13a & NN19 & \multirow{2}{*}{ 12. LAD Discoaster brouweri } & \multirow{2}{*}{1.89} & & \\
\hline CN12d & \multirow{2}{*}{ NN18 } & & & & \\
\hline \multirow{2}{*}{ CN12c } & & 13. LAD Discoaster pentaradiatus & 2.35 & & \\
\hline & NN17 & 14. LAD Discoaster surculus & 2.41 & & \\
\hline $\begin{array}{l}\text { CN12b } \\
\text { CN12a }\end{array}$ & \multirow{2}{*}{ NN16 } & 15. LAD Sphenolithus spp. & 3.45 & $8 \mathrm{H}-4,23-24 / 8 \mathrm{H}-5,23-24$ & $68.27 / 69.72$ \\
\hline \multirow{2}{*}{$\begin{array}{l}\text { CN11b } \\
\text { CN11a }\end{array}$} & & 16. LAD Reticulofenestra pseudoumbilica & 3.56 & $8 \mathrm{H}-\mathrm{CC} / 9 \mathrm{H}-1,23-24$ & $73.20 / 73.42$ \\
\hline & $\begin{array}{l}\text { NN15 } \\
\text { NN13 }\end{array}$ & 17. FAD Ceratolithus rugosus & 4.6 & $12 \mathrm{H}-3,23-24 / 12 \mathrm{H}-4,23-24$ & $104.93 / 106.43$ \\
\hline \multirow{2}{*}{ CN10b } & \multirow{4}{*}{ NN12 } & 18. LAD Ceratolithus acutus & 4.6 & $12 \mathrm{H}-2,23-24 / 12 \mathrm{H}-3,23-24$ & $103.43 / 104.93$ \\
\hline & & 19. FAD Ceratolithus acutus & 4.9 & $13 \mathrm{H}-3,123-124 / 13 \mathrm{H}-4,123-124$ & $115.26 / 116.70$ \\
\hline \multirow{2}{*}{ CN10a } & & 20. LAD Triquetrorhabdulus rugosus & 4.9 & $13 \mathrm{H}-4,123-124 / 13 \mathrm{H}-5,123-124$ & $116.70 / 118.15$ \\
\hline & & 21. LAD Discoaster quinqueramus & 5.0 & $14 \mathrm{H}-1,23-24 / 14 \mathrm{H}-2,23-24$ & $120.92 / 122.36$ \\
\hline \multirow{2}{*}{$\begin{array}{l}\text { CN9b } \\
\text { CN8a }\end{array}$} & NN11 & 22. FAD Discoaster quinqueramus & 7.5 & $24 \mathrm{H}-3,23-24 / 24 \mathrm{H}-4,23-24$ & $218.82 / 220.27$ \\
\hline & NN10 & 23. LAD Discoaster hamatus & 8.7 & $29 X-3,23-24 / 29 X-4,23-24$ & $266.43 / 267.93$ \\
\hline \multirow{2}{*}{ CN7b } & \multirow{3}{*}{ NN9 } & 24. LAD Catinaster spp. & 8.8 & $29 X-3,23-24 / 29 X-4,23-24$ & $266.43 / 267.93$ \\
\hline & & 25. FAD Catinaster calyculus & 10.0 & $30 X-5,23-24 / 30 X-6,23-24$ & $279.13 / 280.63$ \\
\hline CN7a & & 26. FAD Discoaster hamatus & 10.5 & $31 X-1,23-24 / 31 X-2,23-24$ & $282.73 / 284.23$ \\
\hline \multirow{2}{*}{ CN6 } & \multirow{2}{*}{ NN8 } & & & & \\
\hline & & 27. FAD Catinaster coalitus & 11.1 & $31 X-3,23-24 / 31 X-4,23-24$ & $285.73 / 287.23$ \\
\hline \multirow[t]{2}{*}{ CN5b } & \multirow{3}{*}{$\begin{array}{l}\text { NN7 } \\
\text { NN6 }\end{array}$} & 28. LAD Coronocyclus nitescens & 12.8 & $33 X-6,23-24 / 33 X-C C$ & $309.13 / 310.37$ \\
\hline & & 29. LAD Cyclicargolithus floridanus & 13.1 & $34 X-4,23-24 / 34 X-5,23-24$ & $315.73 / 317.23$ \\
\hline CN5a & & 30. LAD Sphenolithus heteromorphus & 13.6 & $35 X-4,23-24 / 35 X-5,23-24$ & $325.23 / 326.73$ \\
\hline \multirow{2}{*}{$\begin{array}{l}\text { CN4 } \\
\text { CN3 } \\
\end{array}$} & \multirow{3}{*}{$\begin{array}{l}\text { NN5 } \\
\text { NN4 }\end{array}$} & & & & \\
\hline & & 31. FAD Sphenolithus heteromorphus & 18.6 & $41 X-C C / 42 X-1,23-24$ & $385.77 / 388.23$ \\
\hline \multirow{3}{*}{ CN2 } & & 32. LAD Sphenolithus belemnos & 18.8 & $42 X-2,25-26 / 42 X-3,23-24$ & $389.75 / 391.23$ \\
\hline & NN3 & 33. LAD Triquetrorhabdulus carinatus & 19.5 & $42 X-2,25-26 / 42 X-3,23-24$ & $389.75 / 391.23$ \\
\hline & \multirow[t]{2}{*}{ NN2 } & 34. FAD Sphenolithus belemnos & 20.0 & $43 X-5,23-24 / 43 X-6,23-24$ & $403.93 / 405.43$ \\
\hline CN1c & & 35. FAD Discoaster druggii & 23.6 & $46 X-1,23-24 / 46 X-2,23-24$ & $426.73 / 428.23$ \\
\hline
\end{tabular}

reticulofenestrid coccoliths ( $>7 \mu \mathrm{m}$ in diameter) are found. The top of this lower part provides for the top of Zone NN15.

Interval $\mathrm{A}_{2}$ : middle NN12-upper NN10

Hole 806B: Samples 130-806B-16H-4, 26-27 cm, to -32H-CC

Hole 805B: Samples 130-805B-12H-CC to $-25 \mathrm{H}-\mathrm{CC}$

Generally speaking, this interval also contains abundant, very small reticulofenestrid coccoliths. Compared with Interval $A_{1}$, however, their relative abundances increase and decrease frequently, and average abundances are $47.5 \%$ in Hole $806 \mathrm{~B}$ and $46.1 \%$ in Hole $805 \mathrm{~B}$, which are not so high as in Interval $\mathrm{A}_{1}$. The lower part of this interval (below Samples 130-806B-26H-4, 26-27 cm, and 130-805B$20 \mathrm{H}-\mathrm{CC}$ ) contains no more very large reticulofenestrid coccoliths (Fig. 10A).
Between Intervals A and B: middle NN10

Hole 806B: Samples 130-806B-33H-4, 26-27 cm, to $-33 \mathrm{H}-\mathrm{CC}$

Hole 805B: Samples 130-805B-26H-4, 23-24 cm, to $-26 \mathrm{H}-\mathrm{CC}$

The first remarkable and abrupt drop in the relative abundance of reticulofenestrid coccoliths that divides Intervals A and B occurs in the late Miocene (in Zone NN10). At this horizon, reticulofenestrid coccolith forms account for only about $1 \%$ of the total flora; instead of Reticulofenestra spp., the flora is characterized by bloomlike, high abundances of small sphenoliths (Sphenolithus abies). A remarkable upward size reduction event in the reticulofenestrid coccolith population takes place at this horizon.

Interval B: lower NN10-middle NN5/NN4

Hole 806B: Samples 130-806B-34H-4, 26-27 cm, to -56X-CC 
Table 12. Neogene calcareous nannofossil datums, Hole 806B.

\begin{tabular}{|c|c|c|c|c|c|}
\hline \multicolumn{2}{|c|}{ Zone } & Species & $\begin{array}{l}\text { Age } \\
\text { (Ma) }\end{array}$ & $\begin{array}{l}\text { Core, section, } \\
\text { interval }(\mathrm{cm})\end{array}$ & Depth (mbsf) \\
\hline CN13a & NN19 & 12. LAD Discoaster brouweri & 1.89 & $5 \mathrm{H}-6,26-27 / 5 \mathrm{H}-7,26-27$ & $42.34 / 43.81$ \\
\hline \multirow{2}{*}{ CN12d } & \multirow[t]{2}{*}{ NN18 } & \multirow{2}{*}{ 13. LAD Discoaster pentaradiatus } & \multirow[b]{2}{*}{2.35} & \multirow{2}{*}{$6 \mathrm{H}-\mathrm{CC} / 7 \mathrm{H}-1,106-107$} & \multirow{2}{*}{$54.00 / 54.51$} \\
\hline & & & & & \\
\hline $\mathrm{CN} 12 \mathrm{C}$ & NN17 & 14. LAD Discoaster surculus & 2.41 & $8 \mathrm{H}-1,106-107 / 8 \mathrm{H}-2,106-107$ & $64.53 / 65.99$ \\
\hline $\begin{array}{l}\text { CN12b } \\
\text { CN12a }\end{array}$ & \multirow[t]{2}{*}{ NN16 } & 15. LAD Sphenolithus spp. & 3.45 & $10 \mathrm{H}-3,26-27 / 10 \mathrm{H}-4,26-27$ & $85.66 / 87.11$ \\
\hline \multirow{2}{*}{$\begin{array}{l}\text { CN11b } \\
\text { CN11a }\end{array}$} & & 16. LAD Reticulofenestra pseudoumbilica & 3.56 & $11 \mathrm{H}-2,26-27 / 11 \mathrm{H}-3,26-27$ & $93.66 / 95.08$ \\
\hline & $\begin{array}{l}\text { NN15 } \\
\text { NN13 }\end{array}$ & 17. FAD Ceratolithus rugosus & 4.6 & $15 \mathrm{H}-6,26-27 / 15 \mathrm{H}-7,26-27$ & $137.43 / 138.87$ \\
\hline \multirow{2}{*}{$\mathrm{CN} 10 \mathrm{~b}$} & \multirow{4}{*}{ NN12 } & 18. LAD Ceratolithus acutus & 4.6 & $15 \mathrm{H}-6,26-27 / 15 \mathrm{H}-7,26-27$ & $137.43 / 138.87$ \\
\hline & & 19. FAD Ceratolithus acutus & 4.9 & $17 \mathrm{H}-2,26-27 / 17 \mathrm{H}-3,26-27$ & $150.69 / 152.13$ \\
\hline \multirow{2}{*}{ CN10a } & & 20. LAD Triquetrorhabdulus rugosus & 4.9 & $17 \mathrm{H}-3,26-27 / 17 \mathrm{H}-4,26-27$ & $152.13 / 153.56$ \\
\hline & & 21. LAD Discoaster quinqueramus & 5.0 & $18 \mathrm{H}-3,26-27 / 18 \mathrm{H}-4,26-27$ & $161.60 / 163.02$ \\
\hline \multirow{2}{*}{$\begin{array}{l}\text { CN9b } \\
\text { CN8a }\end{array}$} & NN11 & 22. FAD Discoaster quinqueramus & 7.5 & $31 \mathrm{H}-2,24-25 / 31 \mathrm{H}-3,26-27$ & $283.65 / 285.09$ \\
\hline & NN10 & 23. LAD Discoaster hamatus & 8.7 & $36 \mathrm{X}-7,26-27 / 36 \mathrm{X}-\mathrm{CC}$ & $338.96 / 339.34$ \\
\hline \multirow[t]{2}{*}{ CN7b } & \multirow{3}{*}{ NN9 } & 24. LAD Catinaster spp. & 8.8 & $37 X-4,26-27 / 37 X-5,26-27$ & $344.16 / 345.66$ \\
\hline & & 25. FAD Catinaster calyculus & 10.0 & $39 \times-3,26-27 / 39 \times-4,26-27$ & $362.06 / 363.56$ \\
\hline CN7a & & 26. FAD Discoaster hamatus & 10.5 & $39 X-6,26-27 / 39 X-C C$ & $366.56 / 367.53$ \\
\hline CN6 & NN8 & 27. FAD Catinaster coalitus & 11.1 & $40 X-5,26-27 / 40 X-C C$ & $374.76 / 375.96$ \\
\hline \multirow[t]{2}{*}{ CN5b } & \multirow{3}{*}{$\begin{array}{l}\text { NN7 } \\
\text { NN6 }\end{array}$} & 28. LAD Coronocyclus nitescens & 12.8 & $45 X-6,26-27 / 45 X-C C$ & $424.66 / 426.27$ \\
\hline & & 29. LAD Cyclicargolithus floridanus & 13.1 & $49 X-C C / 50 X-1,26-27$ & $463.60 / 463.86$ \\
\hline CN5a & & 30. LAD Sphenolithus heteromorphus & 13.6 & $50 X-C C / 51 X-1,26-27$ & $472.03 / 473.56$ \\
\hline $\begin{array}{l}\text { CN4 } \\
\text { CN3 }\end{array}$ & NN5 & 31. FAD Sphenolithus heteromorphus & 18.6 & $61 X-7,26-27 / 61 X-C C$ & $578.86 / 579.30$ \\
\hline & & 32. LAD Sphenolithus belemnos & 18.8 & $61 X-C C / 62 X-1,26-27$ & $579.30 / 579.56$ \\
\hline CN2 & NN3 & 33. LAD Triquetrorhabdulus carinatus & 19.5 & $62 X-7,26-27 / 62 X-C C$ & $588.56 / 589.00$ \\
\hline & NN2 & 34. FAD Sphenolithus belemnos & 20.0 & $64 X-2,30-31 / 64 X-C C$ & $600.40 / 601.63$ \\
\hline CN1c & & 35. FAD Discoaster drugaii & 23.6 & $66 \mathrm{X}-\mathrm{CC} / 67 \mathrm{X}-1,26-27$ & $627.50 / 627.76$ \\
\hline CN1b & NN1 & 30. ThD Discuaster urugg" & & & \\
\hline
\end{tabular}

Hole 805B: Samples $130-805 B-27 \mathrm{H}-4,23-24 \mathrm{~cm}$, to $-40 \mathrm{X}-3$, $23-24 \mathrm{~cm}$

In this interval, reticulofenestrid coccoliths are again abundant. Based on the occurrences of very large and very small reticulofenestrid coccoliths, this interval is divided into three parts: Intervals $B_{1}, B_{2}$, and $\mathrm{B}_{3}$ in descending order.

Interval B1: lower NN10-upper NN7/NN6

Hole 806B: Samples 130-806B-34H-4, 26-27 cm, to $-44 \mathrm{X}-4$, $26-27 \mathrm{~cm}$

Hole 805B: Samples $130-805 B-27 \mathrm{H}-4,23-24 \mathrm{~cm}$, to $-32 \mathrm{X}-3$, $23-24 \mathrm{~cm}$
Interval $B_{1}$ is characterized by the fairly abundant occurrence of reticulofenestrid coccoliths. However, very small specimens of Reticulofenestra are almost absent (Fig. 10B).

Interval B2: middle and lower NN7/NN6

Hole 806B: Samples 130-806B-44X-CC to $-50 \mathrm{X}-\mathrm{CC}$

Hole 805B: Samples $130-805 B-32 X-C C$ to $-35 X-3,23-24 \mathrm{~cm}$

In this interval, very large and very small reticulofenestrid specimens are present, although their relative abundances compared to the total flora are not high (Fig. 10).

Interval B3: upper and middle NN5/NN4 
Table 13. Neogene calcareous nannofossil datums, Hole 807A.

\begin{tabular}{|c|c|c|c|c|c|}
\hline \multicolumn{2}{|c|}{ Zone } & Species & Age & Core, section, & Depth (mbsf) \\
\hline CN13a & NN19 & \multirow{2}{*}{ 12. LAD Discoaster brouweri } & \multirow{2}{*}{1.89} & \multirow{2}{*}{$4 \mathrm{H}-4,104-105 / 4 \mathrm{H}-5,24-25$} & \multirow{2}{*}{$31.70 / 32.37$} \\
\hline CN12d & NN18 & & & & \\
\hline \multirow{2}{*}{ CN12c } & \multirow{2}{*}{ NN17 } & 13. LAD Discoaster pentaradiatus & 2.35 & $5 \mathrm{H}-3,104-105 / 5 \mathrm{H}-4,104-105$ & $39.80 / 41.24$ \\
\hline & & 14. LAD Discoaster surculus & 2.41 & $5 \mathrm{H}-4,104-105 / 5 \mathrm{H}-5,104-105$ & $41.24 / 42.69$ \\
\hline $\begin{array}{l}\text { CN12b } \\
\text { CN12a }\end{array}$ & \multirow[t]{2}{*}{ NN16 } & 15. LAD Sphenolithus spp. & 3.45 & $8 \mathrm{H}-6,24-25 / 8 \mathrm{H}-7,24-25$ & $71.79 / 73.23$ \\
\hline \multirow{2}{*}{$\begin{array}{l}\text { CN11b } \\
\text { CN11a }\end{array}$} & & 16. LAD Reticulofenestra pseudoumbilica & 3.56 & $9 \mathrm{H}-3,104-105 / 9 \mathrm{H}-4,24-25$ & $77.86 / 78.54$ \\
\hline & $\begin{array}{l}\text { NN15 } \\
\text { NN13 }\end{array}$ & 17. FAD Ceratolithus rugosus & 4.6 & $12 \mathrm{H}-\mathrm{CC} / 13 \mathrm{H}-1,24-25$ & $111.90 / 112.14$ \\
\hline \multirow[t]{2}{*}{ CN10b } & \multirow{4}{*}{ NN12 } & 18. LAD Ceratolithus acutus & 4.6 & $12 \mathrm{H}-\mathrm{CC} / 13 \mathrm{H}-1,24-25$ & $111.90 / 112.14$ \\
\hline & & 19. FAD Ceratolithus acutus & 4.9 & $13 \mathrm{H}-\mathrm{CC} / 14 \mathrm{H}-1,23-24$ & $121.40 / 121.62$ \\
\hline \multirow[t]{2}{*}{ CN10a } & & 20. LAD Triquetrorhabdulus rugosus & 4.9 & $14 \mathrm{H}-1,23-24 / 14 \mathrm{H}-2,23-24$ & $121.62 / 123.07$ \\
\hline & & 21. LAD Discoaster quinqueramus & 5.0 & $14 H-6,23-24 / 14 H-7,23-24$ & $128.86 / 130.31$ \\
\hline \multirow{2}{*}{$\begin{array}{l}\text { CN9b } \\
\text { CN8a }\end{array}$} & NN11 & 22. FAD Discoaster quinqueramus & 7.5 & $26 \mathrm{H}-2,24-25 / 26 \mathrm{H}-3,24-25$ & $237.07 / 238.51$ \\
\hline & NN10 & 23. LAD Discoaster hamatus & 8.7 & $30 X-3,24-25 / 30 X-4,24-25$ & $277.04 / 278.54$ \\
\hline \multirow[t]{2}{*}{ CN7b } & \multirow{3}{*}{ NN9 } & 24. LAD Catinaster spp. & 8.8 & $30 \times-5,24-25 / 30 X-6,24-25$ & $280.04 / 281.54$ \\
\hline & & 25. FAD Catinaster calyculus & 10.0 & $32 X-2,24-25 / 32 X-3,24-25$ & $294.44 / 295.94$ \\
\hline CN7a & & 26. FAD Discoaster hamatus & 10.5 & $32 \mathrm{X}-\mathrm{CC} / 33 \mathrm{X}-1,24-25$ & $300.72 / 302.54$ \\
\hline CN6 & NN8 & 27. FAD Catinaster coalitus & 11.1 & $33 X-3,24-25 / 33 X-4,24-25$ & $305.54 / 307.04$ \\
\hline \multirow[t]{2}{*}{ CN5b } & \multirow{3}{*}{$\begin{array}{l}\text { NN7 } \\
\text { NN6 }\end{array}$} & 28. LAD Coronocyclus nitescens & 12.8 & $36 X-3,24-25 / 36 X-4,24-25$ & $334.14 / 335.64$ \\
\hline & & 29. LAD Cyclicargolithus floridanus & 13.1 & $40 X-2,24-25 / 40 X-3,24-25$ & $371.44 / 372.94$ \\
\hline CN5a & & 30. LAD Sphenolithus heteromorphus & 13.6 & $40 X-7,24-25 / 40 X-C C$ & $378.94 / 379.32$ \\
\hline \multirow{2}{*}{$\begin{array}{l}\text { CN4 } \\
\text { CN3 }\end{array}$} & \multirow{3}{*}{$\begin{array}{l}\text { NN5 } \\
\text { NN4 }\end{array}$} & & & & \\
\hline & & 31. FAD Sphenolithus heteromorphus & 18.6 & $49 X-4,24-25 / 49 X-5,24-25$ & $461.54 / 463.04$ \\
\hline \multirow{3}{*}{ CN2 } & & 32. LAD Sphenolithus belemnos & 18.8 & $49 X-5,24-25 / 49 X-C C$ & $463.04 / 464.73$ \\
\hline & NN3 & 33. LAD Triquetrorhabdulus carinatus & 19.5 & $50 X-6,24-25 / 50 X-7,24-25$ & $474.14 / 475.64$ \\
\hline & \multirow[t]{2}{*}{ NN2 } & 34. FAD Sphenolithus belemnos & 20.0 & $50 X-C C / 51 X-1,24-25$ & $475.85 / 476.34$ \\
\hline CN1c & & 35. FAD Discoaster druggil & 23.6 & $61 X-6,24-25 / 61 X-C C$ & $580.04 / 581.14$ \\
\hline
\end{tabular}

Hole 806B: Sample 130-806B-51X-4, 26-27 cm, to -56X-CC Hole 806B: Sample 130-805B-35X-CC to $-40 X-3,23-24 \mathrm{~cm}$

Interval $\mathrm{B}_{3}$ is clearly distinguished from Interval $\mathrm{B}_{2}$ by the almost absence of very large specimens of Reticulofenestra. Therefore, it is clear that another dramatic change in Reticulofenestra coccolith size occurs between Intervals $B_{2}$ and $B_{3}$; that is, a size increase event (Fig. $10 \mathrm{~A})$. As very small reticulofenestrid specimens are present but rare and occasional in this interval (Fig. 10B), the most dominant specimens are between 5 and $3 \mu \mathrm{m}$ in diameter.

Between Intervals B and C: lower NN5/NN4-upper NN2 Hole 806B: Samples 130-806B-57X-4, 26-27 cm, to -62X-CC
Hole 805B: Samples $130-805 B-40 X-C C$ to $-42 X-C C$

The second abrupt drop in the relative abundance of reticulofenestrid coccoliths that divides Intervals $\mathrm{B}$ and $\mathrm{C}$ takes place in the early Miocene (in the lower NN5/NN4 zonal interval down to the upper NN2 Zone). The reduction in the reticulofenestrid coccolith abundance at this horizon, however, is not so remarkable as at the first one. Reticulofenestra specimens form about $8 \%$ of the total floras in Holes 806B and 805B. Instead of Reticulofenestra spp., discoasters and Cyclicargolithus floridanus are dominant at this horizon.

Interval C: middle NN2-upper NN1

Hole 806B: Samples 130-806B-63X-4, 26-27 cm, to -70X-CC 


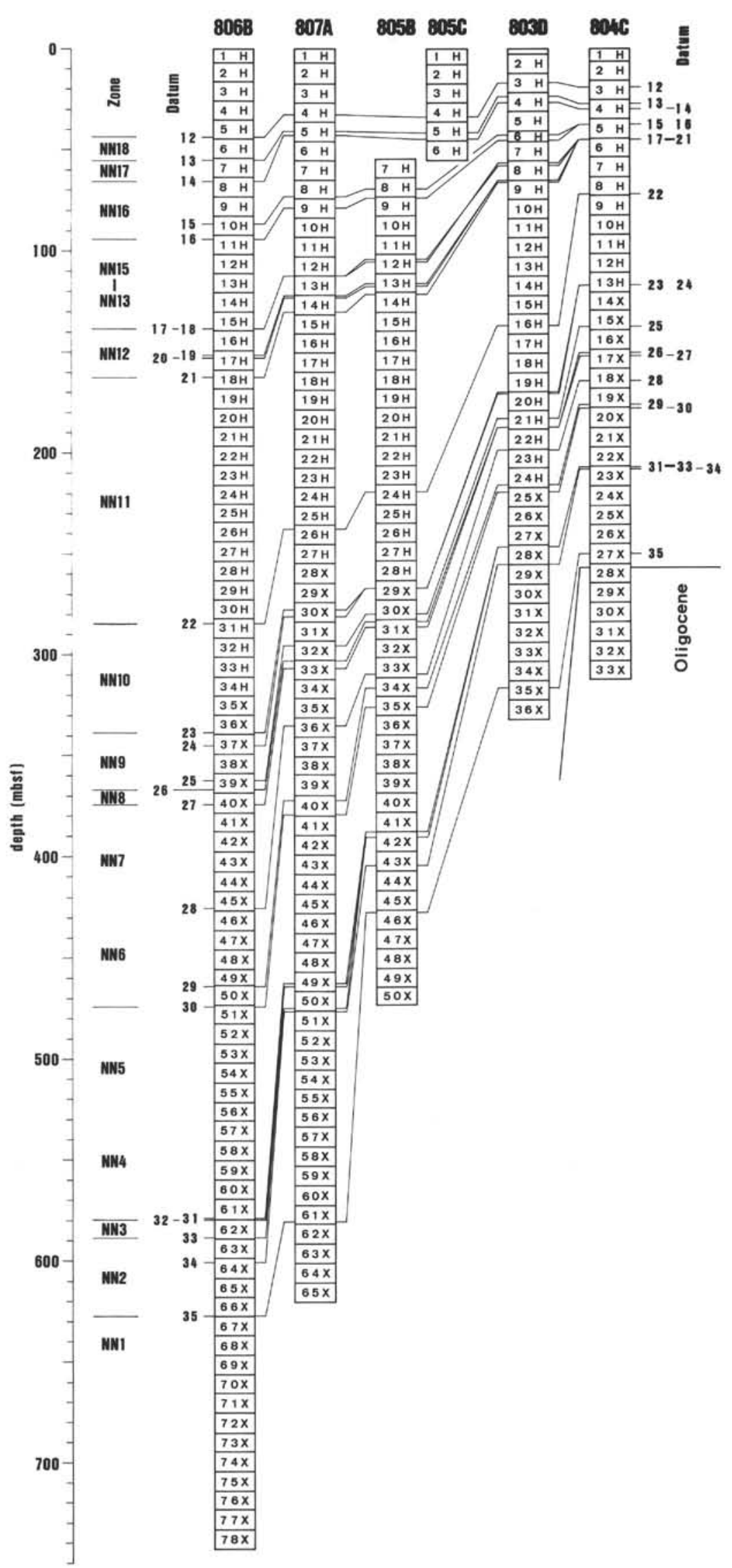

Figure 3. Neogene biostratigraphic relationships at each site of Leg 130. Refer to Table 2 for key to datum numbers. 
Hole 805B: Samples 130-805B-43X-3, 23-24 cm, to $-47 \mathrm{X}-\mathrm{CC}$

In this interval, Reticulofenestra again becomes abundant. The relative abundances, however, are not high compare with Intervals A and B. Maximum abundances are $55.5 \%$ and $58 \%$ in Holes $806 \mathrm{~B}$ and $805 \mathrm{~B}$, respectively. Only middle-sized specimens $(7-3 \mu \mathrm{m}$ in diameter) are abundant.

Below Interval C: lower NN1

Hole 806B: below Sample 130-806B-71X-2, 26-27 cm

Hole 805B: below Sample 130-805B-48X-3, 23-24 cm

Below Interval C, reticulofenestrid coccoliths are very rare. On the contrary, Cyclicargolithus floridanus becomes dominant and takes the place of reticulofenestrid coccoliths.

\section{Remarks}

Because of this investigation, a clear pattern was revealed with a dramatic size reduction event occurring in the late Miocene calcareous nannofossil zone NN10 of Martini's (1971) zonal scheme in the equatorial Pacific. Moreover it became clear that Reticulofenestra specimens are very rare or almost absent at this event. One noteworthy characteristic of the assemblage at this event is the bloomlike, high abundance of small sphenoliths (Sphenolithus abies).

According to Young (1990), calcareous nannofossil assemblages in the interval above this size reduction event are characterized by the absence of reticulofenestrid specimens $>5 \mu \mathrm{m}$ in diameter. Young calls this interval the "small Reticulofenestra interval." I also recognized this "small Reticulofenestra interval" in the sections studied, which corresponds exactly to my lower interval $\mathrm{A}_{2}$ (Fig. 10).

In this investigation, another dramatic size change in the Reticulofenestra coccoliths (size increase event) was recognized between Intervals $\mathrm{B}_{2}$ and $\mathrm{B}_{3}$, which corresponds to the NN6/NN5 boundary.

\section{PRINCIPAL CONCLUSIONS}

Thirty genera and 103 species of calcareous nannofossils were identified during this investigation. A total of 35 calcareous nannofossil datums were detected in the Neogene sequences on the Ontong Java Plateau. Among them, 12 datums in the Pleistocene were tentatively correlated with magnetostratigraphy.

Reticulofenestra coccolith size distribution patterns throughout the Pliocene-Miocene sequences were clarified. In these sequences, Reticulofenestra specimens were dominant in three stratigraphic intervals, which were termed Intervals $\mathrm{A}, \mathrm{B}$, and $\mathrm{C}$ in descending order. Based on Reticulofenestra size distribution patterns, Intervals A and B were subdivided. A dramatic size reduction event in Reticulofenestra specimens that occurred in late Miocene sediments in the western Indian Ocean and the Red Sea was also confirmed in the equatorial Pacific between Intervals A and B. Young's (1990) "small Reticulofenestra interval" corresponds exactly to lower Interval $\mathrm{A}_{2}$ in the present investigation. A dramatic size increase event of Reticulofenestra specimens was recognized between Intervals $\mathrm{B}_{2}$ and $\mathrm{B}_{3}$, which corresponds to the NN6/NN5 boundary.

\section{ACKNOWLEDGMENTS}

I take this opportunity to express my gratitude to Loren W. Kroenke, Wolfgang H. Berger, Thomas R. Janecek, Jan Backman, Robert Mark Leckie, Johanna M. Resig, Kozo Takahashi, Carina Lange, and many of the scientific staff on board the JOIDES Resolution, who provided encouragement, friendship, and valuable advice. I am also grateful to Marie-Pierre Aubry and Sarah E. Mock for their constructive reviews of this chapter. I am indebted to Michio Kato for assistance in table preparation and to Yukie Sato for sample bookkeeping and sample preparation.

\section{REFERENCES}

Backman, J., 1980. Miocene-Pliocene nannofossils and sedimentation rates in the Hatton-Rockall Basin, NE Atlantic Ocean. Stockholm Contrib. Geol., $36: 1-93$,

Backman, J., and Pestiaux, P., 1986. Pliocene Discoaster abundance variations, Deep Sea Drilling Project Site 606: biochronology and paleoenvironmental implications. In Ruddiman, W.F., Kidd, R.B., Thomas, E., et al., Init. Repts. DSDP, 94, Pt. 2: Washington (U.S. Govt. Printing Office), 903-910.

Backman, J., Schneider, D.A., Rio, D., and Okada, H., 1990. Neogene lowlatitude magnetostratigraphy from Site 710 and revised age estimates of Miocene nannofossil datum events. In Duncan, R.A., Backman, J., Peterson, L.C., et al., Proc. ODP, Sci. Results, 115: College Station, TX (Ocean Drilling Program), 217-276.

Backman, J., and Shackleton, N.J., 1983. Quantitative biochronology of Pliocene and early Pleistocene calcareous nannofossils from the Atlantic, Indian and Pacific oceans. Mar. Micropaleontol., 8:141-170.

Berggren, W.A., Kent, D.V., and Van Couvering, J.A., 1985. The Neogene: Part 2. Neogene geochronology and chronostratigraphy. In Snelling, N.J. (Ed.), The Chronology of the Geological Record. Geol. Soc. London Mem., 10:211-260.

Bukry, D., 1973. Low-latitude coccolith biostratigraphic zonation. In Edgar, N.T., Saunders, J.B., et al., Init. Repts. DSDP, 15: Washington (U.S. Govt. Printing Office), 685-703.

Driever, B.W.M., 1988. Calcareous nannofossil biostratigraphy and paleoenvironmental interpretation of the Mediterranean Pliocene. Utrecht Micropaleontol. Bull., 36:1-245.

Fornaciari, E., Raffi, I., Rio, D., Villa, G., Backman, J., and Olafsson, G., 1990. Quantitative distribution patterns of Oligocene and Miocene calcareous nannofossils from western equatorial Indian Ocean. In Duncan, R.A., Backman, J., Peterson, L.C., et al., Proc. ODP, Sci. Results, 115: College Station, TX (Ocean Drilling Program), 237-254.

Gallagher, L., 1989. Reticulofenestra: a critical review of taxonomy and evolution. In Crux, J., and Van Heck, S.E. (Eds.), Nannofossils and Their Applications. Proc. 2nd Int. Nannoplankton Assoc. Symp., London, 1987, 41-45.

Mammerickx, J., and Smith, S.M., 1985. Bathymetry of the North Central Pacific. Geol. Soc. Am. Map and Chart Ser., MC-52.

Martini, E., 1971. Standard Tertiary and Quaternary calcareous nannoplankton zonation. In Farinacci, A. (Ed.), Proc. 2nd Int. Conf. Planktonic Microfossils, Roma: Rome (Ed. Technosci.), 2:739-785.

Okada, H., and Bukry, D., 1980. Supplementary modification and introduction of code numbers to the low-latitude coccolith biostratigraphic zonation (Bukry, 1973; 1975). Mar. Micropaleontol., 5:321-325.

Pujos, A., 1987. Late Eocene to Pleistocene medium-sized and small-sized "Reticulofenestrids." In Stradner, H., and Perch-Nielsen, K. (Ed.), Proc. Int. Nannoplankton Assoc. Meeting, Vienna 1985. Abh. Geol. Bundesanst., 39:239-277.

Rio, D., Backman, J., and Raffi, I., in press. Calcareous Nannofossil Biochronology and the Pliocene/Pleistocene Boundary: Cambridge (Cambridge Univ. Press).

Rio, D., Fornaciari, E., and Raffi, I., 1990. Late Oligocene through early Pleistocene calcareous nannofossils from western equatorial Indian Ocean (Leg 115). In Duncan, R.A., Backman, J., Peterson, L.C., et al., Proc. ODP, Sci. Results, 115: College Station, TX (Ocean Drilling Program), 175-236.

Sato, T., Kameo, K., and Takayama, T., 1991. Coccolith biostratigraphy of the Arabian Sea. In Prell, W.L., Niitsuma, N., et al., Proc. ODP, Sci. Results, 117: College Station, TX (Ocean Drilling Program), 37-54.

Sato, T., and Takayama, T., 1992. A stratigraphically significant new species of the calcareous nannofossil Reticulofenestra asanoi. In Ishizaki, K., and Satio, T. (Eds.), Centenary of Japanese Micropaleontology: Tokyo (Terra Scientific), 457-460.

Sato, T., Takayama, T., Kato, M., Kudo, T., and Kameo, K., 1988. Calcareous microfossil biostratigraphy of the uppermost Cenozoic formations distributed in the coast of the Japan Sea. Part 4: conclusion. Jpn. Assoc. Petrol. Technol, J., 53:475-491.

Takayama, T., 1969. Discoasters from the Lamont Core V21-98 (Preliminary reports of the Philippine Sea cores, part 2). Bull. Nat. Sci. Mus. Tokyo, $12: 431-450$.

Thierstein, H.R., Geitzenauer, K.R., Molfino, B., and Shackleton, N.J., 1977. Global synchroneity of late Quaternary coccolith datum levels: validation by oxygen isotopes. Geology, 5:400-405.

Young, J., 1990. Size variation of Neogene Reticulofenestra coccoliths from Indian Ocean DSDP cores. J. Micropaleontol., 9:71-86. 
Zijderveld, J.D.A., Zachariasses, J.W., Verhallen, P.J.J.M., and Hilgen, F.J., 1986. The age of Miocene-Pliocene boundary. Newsl. Stratigr, 16:169-181.

Date of initial receipt: 6 February 1992

Date of acceptance: 23 June 1992

Ms 130B-020

\section{APPENDIX}

During this investigation, 30 genera and 103 species were recognized. No new species are described in this report, so no taxonomic discussion and systematic description are included. The species names considered in this report are listed alphabetically below.

Amaurolithus amplificus (Bukry and Percival) Gartner and Bukry, 1975 Amaurolithus delicatus Gartner and Bukry, 1975

Amaurolithus primus (Bukry and Percival) Gartner and Bukry, 1975

Amaurolithus tricorniculatus (Gartner) Gartner and Bukry, 1975

Calcidiscus leptoporus (Murray and Blackman) Loeblich and Tappan, 1978

Calcidiscus macintyrei (Bukry and Bramlette) Loeblich and Tappan, 1978

Calcidiscus premacintyrei Theodoridis, 1984

Catinaster altus (Müller) Perch-Nielsen, 1984

Catinaster calyculus Martini and Bramlette, 1963

Catinaster coalitus Martini and Bramlette, 1963

Ceratolithus acutus Gartner and Bukry, 1974

Ceratolithus cristatus Kamptner, 1950

Ceratolithus rugosus Bukry and Bramlette, 1968

Ceratolithus simplex Bukry, 1979

Ceratolithus telesmus Norris, 1965

Coccolithus crassipons Bouché, 1962

Coccolithus eopelagicus (Bramlette and Riedel) Bramlette and Sullivan, 1961

Coccolithus miopelagicus Bukry, 1971

Coccolithus pelagicus (Wallich) Schiller, 1930

Coccolithus streckerii Takayama and Sato, 1987

Coronocyclus nitescens (Kamptner) Bramlette and Wilcoxon, 1967

Cyclicargolithus floridanus (Roth and Hay) Bukry, 1971

Cyclolithella annula (Cohen) McIntyre and Bé, 1967

Dictyococcites productus (Kamptner) Backman, 1980

Discoaster adamanteus Bramlette and Wilcoxon, 1967

Discoaster asymmetricus Gartner, 1969

Discoaster bellus Bukry and Percival, 1971

Discoaster berggrenii Bukry, 1971

Discoaster blackstockae Bukry, 1973

Discoaster bollii Martini and Bramlette, 1963

Discoaster braarudii Bukry, 1971

Discoaster brouweri Tan Sin Hok, 1927

Discoaster calcaris Gartner, 1967

Discoaster challengeri Bramlette and Riedel, 1954

Discoaster decorus (Bukry) Bukry, 1973

Discoaster deflandrei Bramlette and Riedel, 1954

Discoaster druggii Bramlette and Wilcoxon, 1967

Discoaster exilis Martini and Bramlette, 1963

Discoaster formosus Martini and Worsley, 1971

Discoaster hamatus Martini and Bramlette, 1963

Discoaster intercalaris Bukry, 1971

Discoaster kugleri Martini and Bramlette, 1963

Discoaster loeblichii Bukry, 1971

Discoaster moorei Bukry, 1971
Discoaster neohamatus Bukry and Bramlette, 1969

Discoaster neorectus Bukry, 1971

Discoaster pansus (Bukry and Percival) Bukry, 1973

Discoaster pentaradiatus Tan Sin Hok, 1927

Discoaster prepentaradiatus Bukry and Percival, 1971

Discoaster pseudovariabilis Martini and Worsley, 1971

Discoaster quadramus Bukry, 1973

Discoaster quinqueramus Gartner, 1969

Discoaster surculus Martini and Bramlette, 1963

Discoaster tamalis Kamptner, 1967.

Discoaster triradiatus Tan Sin Hok, 1927

Discoaster tristellifer Bukry, 1976

Discoaster variabilis Martini and Bramlette, 1963

Discolithina japonica Takayama, 1967

Ericsonia obruta Perch-Nielsen, 1971

Gephyrocapsa aperta Kamptner, 1963

Gephyrocapsa sinuosa Hay and Beaudry, 1973

Hayaster perplexus (Bramlette and Riedel) Bukry, 1973

Helicosphaera carteri (Wallich) Kamptner, 1954

Helicosphaera euphratis Haq, 1966

Helicosphaera granulata Bukry and Percival, 1971

Helicosphaera hyalina Gaarder, 1970

Helicosphaera intermedia Martini, 1965

Helicosphaera neogranulata Gartner, 1977

Helicosphaera recta Haq, 1966

Helicosphaera sellii Bukry and Bramlette, 1969

Helicosphaera wallichii (Lohmann) Boudreaux and Hay, 1969

Oolithotus fragilis (Lohmann) Martini and Müller, 1972

Orthorhabdus serratus Bramlette and Wilcoxon, 1967

Pontosphaera spp.

Pseudoemiliania lacunosa (Kamptner) Gartner, 1969

Reticulofenestra ampla Sato, Kameo and Takayama, 1991

Reticulofenestra asanoi Sato and Takayama, 1992

Reticulofenestra gelida (Geitzenauer) Backman, 1978

Reticulofenestra haqii Backman, 1978

Reticulofenestra minuta Roth, 1970

Reticulofenestra minutula (Gartner) Haq and Berggren, 1978

Reticulofenestra pseudoumbilica (Gartner) Gartner, 1969

Rhabdosphaera claviger Murray and Blackman, 1898

Rhabdosphaera stylifer Lohmann, 1902

Scapholithus fossilis Deflandre, 1954

Scyphosphaera spp.

Solidopons petrae Theodoridis, 1984

Sphenolithus abies Deflandre, 1954

Sphenolithus belemnos Bramlette and Wilcoxon, 1967

Sphenolithus ciperoensis Bramlette and Wilcoxon, 1967

Sphenolithus compactus Backman, 1980

Sphenolithus conicus Bukry, 1971

Sphenolithus delphix Bukry, 1973

Sphenolithus dissimilis Bukry and Percival, 1971

Sphenolithus distentus (Martini) Bramlette and Wilcoxon, 1967

Sphenolithus grandis Haq and Berggren, 1978

Sphenolithus heteromorphus Deflandre, 1953

Sphenolithus moriformis (Brönnimann and Stradner) Bramlette and Wilcoxon, 1967

Syracosphaera pulchra Lohmann, 1902

Tetralithides symeonidesii Theodoridis, 1984

Triquetrorhabdulus carinatus Martini, 1965

Triquetrorhabdulus milowii Bukry, 1971

Triquetrorhabdulus rugosus Bramlette and Wilcoxon, 1967

Umbilicosphaera sibogae (Weber-van Bosse) Gaarder, 1970

Zygrhablithus bijugatus (Deflandre) Deflandre, 1959 
Table 14. Calcareous nannofossil occurrences, Hole 806B.

\begin{tabular}{|c|c|c|c|c|}
\hline Coro & $5 \mathrm{H}$ & $5 \mathrm{H}$ & $6 \mathrm{H}$ & $6 \mathrm{H}$ \\
\hline Section & 4 & $\propto$ & 4 & $\propto$ \\
\hline Intorval $(\mathrm{cm})$ & $26 \cdot 27$ & & $26 \cdot 27$ & \\
\hline Zono (Matini, 1971) & NN19 & & NN18 & \\
\hline Amaurolithus amplificus & & & & \\
\hline Amaurolithus delicatus & & & & \\
\hline Amaurolithus primus & & & & \\
\hline Amaurolithus tricomiculatus & & & & \\
\hline Calcidiscus leptoporus & 26 & 25 & 15 & 16 \\
\hline Calcidiscus macintyroi & + & + & + & + \\
\hline Calcidiscus premacintyroi & & & & \\
\hline Catinaster calyculus & & & & \\
\hline Catinaster coalitus & & & & \\
\hline Coratolithus acutus & & & & \\
\hline Ceratolithus rugosus & & + & & ? \\
\hline Coccolithus crassipons & & + & + & + \\
\hline Coccolithus miopelagicus & & & & \\
\hline Coccolithus pelagicus & + & 3 & + & 2 \\
\hline Coccolithus streckeril & & & + & \\
\hline Coronocyclus nitescens & & & & \\
\hline Cyclicargolithus floridanus & & & & \\
\hline Cycloilthella annula & & & & \\
\hline Dictyococcites productus & 2 & & 4 & \\
\hline Discoaster adamantous & & & & \\
\hline Discoastor asymmotricus & & & & \\
\hline Discoastor bollus & & & & \\
\hline Discoaster berggrenli & & & & \\
\hline Discoaster blackstockae & & & & \\
\hline Discoastor bollii & & & & \\
\hline Discoastor brouweri & & + & 9 & 8 \\
\hline Discoastor calcaris & & & & \\
\hline Discoaster challengeri & & & & \\
\hline Discoaster decorus & & & & \\
\hline Discoaster deflandroi & & & & \\
\hline Discoastor druggii & & & & \\
\hline Discoaster exillis & & & & \\
\hline Discoastor formosus & & & & \\
\hline Discoaster hamatus & & & & \\
\hline Discoaster kuglen & & & & \\
\hline Discoaster loeblichili & & & & \\
\hline Discoastor neohamatus & & & & \\
\hline Discoastor neoroctus & & & & \\
\hline Discoastor pansus & & & & \\
\hline Discoaster pentaradiatus & & & & \\
\hline Discoaster propentaradiatus & & & & \\
\hline Discoastor quinquoramus & & & & \\
\hline Discoastor surculus & & & & \\
\hline Discoaster triradiatus & & + & & \\
\hline Discoaster variabilis & & & & \\
\hline Discoaster spp. & & & & \\
\hline Discolithina japonica & & + & & \\
\hline Ericsonia obruta & & & & \\
\hline Gephyrocapsa aperta & 4 & & 3 & 1 \\
\hline Gephyrocapsa sinuosa & & 1 & 2 & \\
\hline smal Gephyrocapsa & 8 & 2 & & \\
\hline Hayaster perplexus & & & & \\
\hline Holicosphaera carteri & + & 2 & 2 & 1 \\
\hline Helicosphaera ouphratis & & & & \\
\hline Helicosphaora granulata & & 1 & & \\
\hline Helicosphaera hyalina & & & & \\
\hline Helicosphaora intormedia & & & & \\
\hline Helicosphaera neogranulata & & & & $?$ \\
\hline Helicosphaera selli & 5 & + & 2 & 2 \\
\hline Helicosphaora wallichii & & + & + & 1 \\
\hline Oolithotus fragilis & 1 & 1 & 5 & \\
\hline Pontosphaera spp. & & + & + & + \\
\hline Psoudoemiliania lacunosa & 8 & 8 & 3 & 2 \\
\hline Roficulofenestra ampla & & & & \\
\hline Reticulofonestra asanol & 1 & + & 2 & \\
\hline Roticulofenestra gelida & & & & \\
\hline Reticulofenestra hagi & & & & \\
\hline Reticulofonestra minuta & 86 & 74 & 132 & 108 \\
\hline Reticulofenestra minutula & 46 & 72 & 15 & 47 \\
\hline Reticulofenestra psoudoumbilica & & & & \\
\hline Rhabdosphaora davigor & & & & 1 \\
\hline Rhabodsphaera stylifor & & & & \\
\hline Scapholithus fossilis & & & & \\
\hline Scyphosphaera spp. & & & & \\
\hline Sphonolithus abies & & & & \\
\hline Sphonolithus belemnos & & & & \\
\hline Sphenolithus compactus & & & & \\
\hline Sphonolithus coricus & & & & \\
\hline Sphenolithus delphix & & & & \\
\hline Sphonolithus dissimilis & & & & \\
\hline Sphenolithus grandis & & & & \\
\hline Sphenolithus hetoromorphus & & & & \\
\hline Sphenolithus moriformis & & & & \\
\hline Syracosphaera pulchra & 2 & 1 & + & + \\
\hline Tetralithides symeonidesii & & 1 & 1 & + \\
\hline Triquotrorhabdus carinatus & & & & \\
\hline Triquatrorhabdus milowii & & & & \\
\hline Triquetrorhabdus rugosus & & & & \\
\hline Umbilicosphaera sibogao & 11 & 9 & 5 & 11 \\
\hline Miscollanoous & & & & \\
\hline
\end{tabular}

Note: $+=$ trace and ? = present but questionable. 
Table 14 (continued).

\begin{tabular}{|c|c|c|c|c|}
\hline Core & $11 \mathrm{H}$ & $12 \mathrm{H}$ & $12 \mathrm{H}$ & $13 \mathrm{H}$ \\
\hline Soction & $\propto$ & 4 & $\mathrm{CC}$ & 4 \\
\hline Intorval $(\mathrm{cm})$ & & $26 \cdot 27$ & & $25 \cdot 26$ \\
\hline Zone (Matini, 1971) & & & & \\
\hline Amaurolithus amplificus & & & & \\
\hline Amaurolithus dolicatus & & & & \\
\hline Amaurolithus primus & & & & \\
\hline Amaurolithus tricomiculatus & & & & $?$ \\
\hline Calcidiscus leptoporus & 18 & 16 & 2 & 7 \\
\hline Calcidiscus macintyrol & 2 & $?$ & + & 1 \\
\hline Calcidiscus promadintyroi & & & & \\
\hline Catinaster calyculus & & & & \\
\hline Catinaster coalitus & & & & \\
\hline Coratolithus acutus & & & & \\
\hline Ceratolithus rugosus & $?$ & & + & + \\
\hline Coccolithus crassipons & & & & \\
\hline Coccolithus miopolagicus & & & & \\
\hline Coccolithus polagicus & & & & \\
\hline Coccolithus strockeril & & & & \\
\hline Coronocyclus nitescons & & & & \\
\hline Cyclicargolithus filoridanus & & & & \\
\hline Cyclolitholla annula & 11 & & + & 5 \\
\hline Dictyocaccites productus & 1 & & & 4 \\
\hline Discoastor adamantous & & & & \\
\hline Discoaster asymmetricus & $?$ & $?$ & & + \\
\hline Discoaster bellus & & & & \\
\hline Discoaster berggrenii & & & & \\
\hline Discoaster blackstockae & & & & \\
\hline Discoaster bolii & & & & \\
\hline Discoaster brouweri & 1 & 2 & + & + \\
\hline Discoaster calcaris & & & & \\
\hline Discoaster challengeri & $?$ & & & \\
\hline Discoaster docorus & & & & \\
\hline Discoaster deffandrei & & & & \\
\hline Discoastor druggi & & & & \\
\hline Discoastor exilis & & & & \\
\hline Discoaster formosus & & & & \\
\hline Discoaster hamatus & & & & \\
\hline Discoastor kuglori & & & & \\
\hline Discoaster looblichii & & & & \\
\hline Discoaster neohamatus & & & & \\
\hline Discoaster neorectus & & & & \\
\hline Discoester pansus & & & & \\
\hline Discoastor pentaradiatus & $?$ & 1 & $?$ & $?$ \\
\hline Discoastor propentaradiatus & & & & \\
\hline Discoaster quinqueramus & & & & \\
\hline Discoaster surculus & $?$ & & + & + \\
\hline Discoaster triradiatus & $?$ & & & $?$ \\
\hline Discoastor variabilis & 1 & $?$ & $?$ & ? \\
\hline Discoaster spp. & & 2 & & \\
\hline Discolithina Japonica & & & & \\
\hline Ericsonia obruta & & & & \\
\hline Gephyrocapsa aperta & 2 & & 1 & \\
\hline Gophyrocapsa sinuosa & & & & \\
\hline smal Gephyrocapsa & 1 & 1 & & \\
\hline Hayaster perploxus & & & + & + \\
\hline Helicosphaera carten & 2 & 3 & + & 5 \\
\hline Helicosphaora ouphratis & & & & \\
\hline Helicosphaera granulata & & & & \\
\hline Helicosphaora hyalina & & & & \\
\hline Helicosphaora intermedia & & & & \\
\hline Helicosphaera neogranulata & & & & \\
\hline Holicosphaera sollii & $?$ & ? & $?$ & $?$ \\
\hline Holicosphaora wallichii & $?$ & & & $?$ \\
\hline Oolithotus fragilis & 3 & 4 & & \\
\hline Pontosphaera spp. & & & & + \\
\hline Psoudoomliania lacunosa & & $?$ & $?$ & \\
\hline Roticulotonestra ampla & & & & \\
\hline Rebiculofenestra asanol & & & & \\
\hline Reticulotenestra gelida & 3 & 2 & + & 1 \\
\hline Roticulofonostra haqii & & & & \\
\hline Roticulofonestra minuta & 78 & 95 & 169 & 129 \\
\hline Roticulofonostra minutula & 30 & 5 & 5 & 6 \\
\hline Reticulofonestra pseudoumbilica & 5 & 6 & 1 & 5 \\
\hline Ahabdosphaera daviger & & & & \\
\hline Rhabodsphaora stylifor & & & & \\
\hline Scapholithus fossilis & & & & \\
\hline Scyphosphaora spp. & & & & \\
\hline Sphenolithus abies & 38 & 47 & 19 & 27 \\
\hline Sphonolithus belernnos & & & & \\
\hline Sphonolithus compactus & & & & \\
\hline Sphonolithus conicus & & & & \\
\hline Sphenolithus delphox & & & & \\
\hline Sphenolithus dissimilis & & & & \\
\hline Sphenolithus grandis & & & & \\
\hline Sphenolithus hetoromorphus & & & & \\
\hline Sphenolithus moritormis & ? & & & 4 \\
\hline Syracosphaora pulchra & & & & + \\
\hline Tetralitidides symeonidosii & + & 2 & 1 & 3 \\
\hline Triquotrorhabdus carinatus & & 1 & & \\
\hline Triquetrorhabdus milowii & & & & \\
\hline Triquetrorhabdus rugosus & & & & \\
\hline Umbilicosphaora sibogae & 4 & 12 & 2 & 2 \\
\hline Miscollaneous & & 1 & & 1 \\
\hline
\end{tabular}


Table 14 (continued).

\begin{tabular}{|c|c|c|c|c|}
\hline Core & $19 \mathrm{H}$ & $20 \mathrm{H}$ & $20 \mathrm{H}$ & $21 \mathrm{H}$ \\
\hline Section & $\propto$ & 4 & $\propto$ & 4 \\
\hline Interval $(\mathrm{cm})$ & & $26-27$ & & $26-27$ \\
\hline Zone (Matini, 1971) & & & & \\
\hline Amaurolithus amplificus & & & $?$ & \\
\hline Amaurolithus delicatus & & & & \\
\hline Amaurolithus primus & & & & \\
\hline Amaurolithus tricomiculatus & & & & \\
\hline Calcidiscus leptoporus & 5 & 2 & 12 & 8 \\
\hline Calcidiscus macintyrol & + & 1 & $?$ & $?$ \\
\hline Calcidiscus premacintyroi & + & 2 & $?$ & 1 \\
\hline Catinastor calyculus & & & & \\
\hline Catinaster coalitus & & & & \\
\hline Coratolithus acutus & & & & \\
\hline Coratolithus rugosus & & & & \\
\hline Coccolithus crassipons & & & & \\
\hline Coccolithus miopolagicus & & & & \\
\hline Coccolithus pelagicus & + & + & + & \\
\hline Coccolithus streckerii & & + & & \\
\hline Coronocyclus nitoscons & & & & \\
\hline Cyclicargolithus floridanus & & & & \\
\hline Cycloithella annula & 5 & $?$ & 3 & + \\
\hline Dictyococcites productus & & & 4 & \\
\hline Discoaster adamantous & & & & \\
\hline Discoaster asymmotricus & & $?$ & & \\
\hline Discoaster bollus & & & & \\
\hline Discoaster berggrenii & + & & $?$ & 1 \\
\hline Discoaster blackstockae & & & & \\
\hline Discoaster bolliti & & & & \\
\hline Discoaster brouwori & + & + & + & + \\
\hline Discoaster calcaris & & & & \\
\hline Discoaster challengeri & & + & + & \\
\hline Discoaster decorus & & & & \\
\hline Discoastor deflandrof & & & & \\
\hline Discoaster druggi & & & & \\
\hline Discoastor axilis & & & & \\
\hline Discoaster formosus & & & & \\
\hline Discoaster hamatus & & & & \\
\hline Discoastor kuglori & & & & \\
\hline Discoaster looblichii & & & & \\
\hline Discoaster neohamatus & & & & $?$ \\
\hline Discoaster nooroctus & $?$ & & & 1 \\
\hline Discoastor pansus & & & & \\
\hline Discoaster pentaradiatus & + & $?$ & + & + \\
\hline Discoaster propentaradiatus & & & & \\
\hline Discoastor quinqueramus & & + & + & 1 \\
\hline Discoaster surculus & + & 1 & + & + \\
\hline Discoaster triradiatus & & + & & ? \\
\hline Discoastor variabilis & + & + & + & \\
\hline Discoastor spp. & & 3 & & 1 \\
\hline Discolithina japonica & & & & \\
\hline Ericsonia obruta & & & & \\
\hline Gephyrocapsa aperta & & & & \\
\hline Gophyrocapsa sinuosa & & & & \\
\hline small Gephyrocapsa & & & & \\
\hline Hayaster perploxus & 1 & + & $?$ & + \\
\hline Helicosphaora cartori & 1 & + & + & + \\
\hline Helicosphaera ouphrafis & & & & \\
\hline Helicosphaora granulata & 1 & 1 & 1 & + \\
\hline Holicosphaora hyalina & & & & \\
\hline Holicosphaera intermedia & & & & \\
\hline Holicosphaora neogranulata & & & & \\
\hline Helicosphaora sollii & & & & \\
\hline Helicosphaera wallichii & 1 & & & $?$ \\
\hline Oolithotus fragilis & & & & \\
\hline Pontosphaera spp. & + & + & + & + \\
\hline Psoudoomliania lacunosa & & & & \\
\hline Reticulofenestra ampla & & & & \\
\hline Roticulofonestra asanol & & & & \\
\hline Roticulofonestra golida & 10 & 3 & + & 5 \\
\hline Rebiculotenestra haqii & 17 & 7 & 4 & 9 \\
\hline Reticulofonostra minuta & 50 & 53 & 108 & 72 \\
\hline Reticulotonestra minutula & 33 & 54 & 29 & 22 \\
\hline Reticulofenestra psoudoumbilica & 3 & 4 & 2 & 13 \\
\hline Ahabdosphaera daviger & & & & \\
\hline Rhabodsphaora stylifer & & & & \\
\hline Scapholithus fossilis & & & & \\
\hline Scyphosphaera spp. & + & + & + & + \\
\hline Sphenolithus abies & 73 & 69 & 34 & 63 \\
\hline Sphenolithus belemnos & & & & \\
\hline Sphenolithus compactus & & & 1 & 2 \\
\hline Sphenolithus conicus & & & & \\
\hline Sphonolithus dolphix & & & & \\
\hline Sphonolithus dissimilis & & & & \\
\hline Sphonolithus grandis & & & & \\
\hline Sphenolithus hetoromorphus & & & & \\
\hline Sphenolithus moriformis & & & 1 & \\
\hline Syracosphaera pulchra & & & & \\
\hline Tetralitides symeonidosii & & + & & 1 \\
\hline Triquetrorhabdus carinatus & & & & \\
\hline Triquetrorhabdus milowii & & & & \\
\hline Triquatrorhabdus rugosus & + & + & + & + \\
\hline Umbilicosphaera sibogae & & & & \\
\hline Miscollaneous & & & 1 & \\
\hline
\end{tabular}


Table 14 (continued).

\begin{tabular}{|c|c|c|c|c|}
\hline Core & $27 \mathrm{H}$ & $28 \mathrm{H}$ & $28 \mathrm{H}$ & $29 \mathrm{H}$ \\
\hline Section & $\propto$ & 4 & $\propto$ & 4 \\
\hline Intorval $(\mathrm{cm})$ & & $26 \cdot 27$ & & $26-27$ \\
\hline Zone (Matini, 1971) & & & & NN \\
\hline Amaurolithus amplificus & & & & \\
\hline Amaurolithus dolicatus & & & & \\
\hline Amaurolithus primus & & & & \\
\hline Amaurolithus tricomiculatus & & & & \\
\hline Calcidiscus loptoporus & 17 & 3 & 12 & 9 \\
\hline Calcidiscus macintyrol & 1 & + & + & 2 \\
\hline Calcidiscus premadintyroi & 1 & + & + & + \\
\hline Catinaster calyculus & & & & \\
\hline Catinastor coalitus & & & & \\
\hline Coratolithus acutus & & & & \\
\hline Ceratolithus nugosus & & & & \\
\hline Coccolithus crassipons & & & & \\
\hline Coccoliturus miopolagicus & & & & \\
\hline Coccolithus pelagicus & 1 & 3 & + & 5 \\
\hline Coccolithus strockeril & $?$ & & & $?$ \\
\hline Coronocyclus nitescens & $?$ & 1 & & $?$ \\
\hline Cyclicargolithus floridanus & & & & \\
\hline Cyclolitholla annula & 2 & + & 2 & 2 \\
\hline Dictyococcites productus & 1 & 5 & & \\
\hline Discoaster adamanteus & & & & \\
\hline Discoaster asymmotricus & & & & \\
\hline Discoaster bellus & $?$ & $?$ & & \\
\hline Discoaster berggrenii & + & + & + & + \\
\hline Discoastor blackstockae & & & & \\
\hline Discoaster bollii & & & & \\
\hline Discoaster brouwori & + & + & + & + \\
\hline Discoaster calcaris & & & & \\
\hline Discoaster challongen & $?$ & & + & \\
\hline Discoaster decorus & & & & \\
\hline Discoaster deflandrei & & & & \\
\hline Discoastor druggi & & & & \\
\hline Discoaster oxilis & & & & \\
\hline Discoaster formosus & & & & \\
\hline Discoaster hamatus & & & & \\
\hline Discoaster kuglorí & & & & \\
\hline Discoastor looblichii & & & & \\
\hline Discoaster neohamatus & & & & $?$ \\
\hline Discoaster neorectus & + & & & \\
\hline Discoaster pansus & & & & \\
\hline Discoaster pontaradiatus & + & & & \\
\hline Discoester prepentaradiatus & & & & \\
\hline Discoastor quinqueramus & + & $?$ & $?$ & \\
\hline Discoaster surculus & + & + & & \\
\hline Discoaster triradiatus & $?$ & & & \\
\hline Discoaster variabilis & + & + & + & + \\
\hline Discoaster spp. & & & & \\
\hline Discolithina japonica & & & & \\
\hline Ericsonia obruta & 1 & 2 & 1 & \\
\hline Gephyrocapsa aperta & & & & \\
\hline Gophyrocapsa sinuosa & & & & \\
\hline smal Gophyrocapsa & & & & \\
\hline Hayaster perplexus & & & & + \\
\hline Holicosphaora cartori & 1 & 1 & + & + \\
\hline Helicosphaora ouphratis & & & & \\
\hline Hollicosphaera granulata & + & + & 1 & + \\
\hline Holicosphaera hyalina & & & & \\
\hline Hellicosphaera intermedia & & & & $?$ \\
\hline Helicosphaera noogranulata & & & & \\
\hline Helicosphaera sollii & & & & \\
\hline Holicosphaora wallichii & & & $?$ & $?$ \\
\hline Oolithotus tragilis & & & & \\
\hline Pontosphaera spp. & + & + & & \\
\hline Psoudoemliliania lacunosa & & & & \\
\hline Roticulotenostra ampla & & & & \\
\hline Reticulofenestra asanol & & & & \\
\hline Rebiculofenestra golida & & & & 1 \\
\hline Roticulofonostra haqi & 40 & 40 & 54 & 63 \\
\hline Roticulofonostra minuta & 46 & 70 & 70 & 47 \\
\hline Roticulotonostra minutula & 37 & 12 & 20 & 15 \\
\hline Reticulofenestra pseudoumbilica & & & & \\
\hline Rhabdosphaera daviger & & & & \\
\hline Phabodsphaora styifor & & & & \\
\hline Scapholithus fossilis & & & & \\
\hline Scyphosphaera spp. & + & + & + & + \\
\hline Sphenolithus abios & 52 & 63 & 39 & 53 \\
\hline Sphenolithus belemnos & & & & \\
\hline Sphonolithus compactus & & & 1 & 3 \\
\hline Sphenolithus conicus & & & & \\
\hline Sphenolithus delphix & & & & \\
\hline Sphonolithus dissimilis & & & & \\
\hline Sphonolithus grandis & & & & \\
\hline Sphenolithus hetoromorphus & & & & \\
\hline Sphenolithus moriformis & & & + & \\
\hline Syracosphaora pulchra & & & & \\
\hline Totralithides symeonidesii & & & + & + \\
\hline Triquetrorhabdus carinatus & & & & \\
\hline Triquotrothabdus milowii & & & & \\
\hline Triquetrorhabdus rugosus & + & + & + & + \\
\hline Umbilicosphaora sibogae & & & & \\
\hline Miscellaneous & & & & \\
\hline
\end{tabular}


Table 14 (continued).

\begin{tabular}{|c|c|c|c|c|}
\hline Cono & $35 X$ & $36 \mathrm{X}$ & $36 \mathrm{X}$ & $37 X$ \\
\hline Soction & $\propto$ & 4 & $\propto$ & 3 \\
\hline Interval $(\mathrm{cm})$ & & $26-27$ & & $26-27$ \\
\hline Zone (Mabini, 1971) & $\mathrm{NN}$ & & & \\
\hline Amaurolithus ampliffcus & & & & \\
\hline Amaurolithus dolicatus & & & & \\
\hline Amaurolithus primus & & & & \\
\hline Amaurolithus tricomiculatus & & & & \\
\hline Calcidiscus leptoporus & 4 & 12 & 5 & 18 \\
\hline Calcidiscus macintyroi & 3 & 3 & 4 & 8 \\
\hline Calcidiscus promadintyrol & + & + & 3 & 5 \\
\hline Catinaster calyculus & & & & \\
\hline Catinaster coalitus & & & & \\
\hline Ceratolithus acutus & & & & \\
\hline Ceratolithus rugosus & & & & \\
\hline Coccolithus crassipons & & & & \\
\hline Coccolithus miopelagicus & $?$ & 11 & $?$ & 1 \\
\hline Coccolithus pelagicus & 11 & 14 & 6 & 4 \\
\hline Coccolithus streckerii & & & $?$ & \\
\hline Coronocyclus nitescens & & & & \\
\hline Cyclicargolithus floridanus & & & & \\
\hline Cyclolithella annula & 1 & & 2 & $?$ \\
\hline Dictyococcitos productus & & & & \\
\hline Discoaster adamantous & & & & \\
\hline Discoastor asymmotricus & & & & \\
\hline Discoastor bellus & & & $?$ & 1 \\
\hline Discoaster berggrenil & & & & \\
\hline Discoaster blackstockae & & & & \\
\hline Discoastor bollii & & & & \\
\hline Discoaster brouweri & $?$ & & & \\
\hline Discoaster calcaris & + & 3 & 1 & 1 \\
\hline Discoaster challengeri & & & 2 & \\
\hline Discoaster decorus & & & & \\
\hline Discoastor deflandrei & & & & \\
\hline Discoastor druggii & & & & \\
\hline Discoastor oxilis & & & & \\
\hline Discoaster formosus & & & & \\
\hline Discoaster hamatus & & $?$ & + & 3 \\
\hline Discoaster kuglori & & & & \\
\hline Discoaster looblichii & & & & \\
\hline Discoastor noohamatus & 1 & 1 & 3 & \\
\hline Discoastor neoroctus & & & & \\
\hline Discoastor pansus & & & $?$ & \\
\hline Discoaster pentaradatus & & & & \\
\hline Discoaster prepentaradiatus & 1 & & + & \\
\hline Discoastor quinqueramus & & & & \\
\hline Discoaster surculus & & & & $?$ \\
\hline Discoaster triradiatus & & & & \\
\hline Discoaster variabilis & + & 2 & 3 & 1 \\
\hline Discoaster spp. & 3 & 8 & & 5 \\
\hline Discollthina japonica & & & & \\
\hline Ericsonia obruta & & & & \\
\hline Gephyrocapsa aperta & & & & \\
\hline Gephyrocapsa sinuosa & & & & \\
\hline smal Gophyrocapsa & & & & \\
\hline Hayaster perplexus & + & & + & 2 \\
\hline Helicosphaora carterí & & & & \\
\hline Helicosphaera ouphratis & & & & \\
\hline Holicosphaora granulata & + & + & 1 & 1 \\
\hline Holicosphaera hyalina & & & & \\
\hline Holicosphaora intermedia & & & & \\
\hline Helicosphaera neogranulata & & & & \\
\hline Helicosphaera sollii & & & & \\
\hline Holicosphaera wallichii & & & & \\
\hline Oolithotus fragilis & & & & \\
\hline Pontosphaora spp. & & + & & \\
\hline Psoudoemiliania lacunosa & & & & \\
\hline Reticulofenestra ampla & & & & \\
\hline Roticulofenestra asanol & & & & \\
\hline Roticulofonestra golida & 82 & 84 & 103 & 102 \\
\hline Resculofenestra hagi & 8 & 1 & 13 & 2 \\
\hline Reticulofonestra minuta & & & 1 & \\
\hline Reticulofonestra minutula & & 1 & 7 & \\
\hline Rebiculofenestra psoudoumbilica & 10 & 11 & 8 & 10 \\
\hline Rhabdosphaera davigor & & & & \\
\hline Ahabodsphaera styifer & & & & \\
\hline Scapholithus fossilis & & & & \\
\hline Scyphosphaera spp. & & & + & \\
\hline Sphonolithus abies & 54 & 27 & 17 & 20 \\
\hline Sphenolithus belemnos & & & & \\
\hline Sphonolithus compactus & 7 & 8 & 9 & 4 \\
\hline Sphonolithus conicus & & & & \\
\hline Sphenolithus delphix & & & & \\
\hline Sphenolithus dissimilis & & & & \\
\hline Sphenolithus grandis & & & & \\
\hline Sphenolithus heteromorphus & & & & \\
\hline Sphonolithus moriformis & 8 & 1 & 8 & 7 \\
\hline Syracosphaera pulchra & & & & \\
\hline Totralithides symeonidesii & & & + & \\
\hline Triquetrorhabdus carinatus & & & & \\
\hline Triquetrorhabdus milowil & & 1 & & \\
\hline Triquetrorhabdus nugosus & 1 & 4 & 2 & 5 \\
\hline Umbliccosphaera sibogae & & & & \\
\hline Miscelaneous & 6 & 10 & 1 & 2 \\
\hline
\end{tabular}


Table 14 (continued).

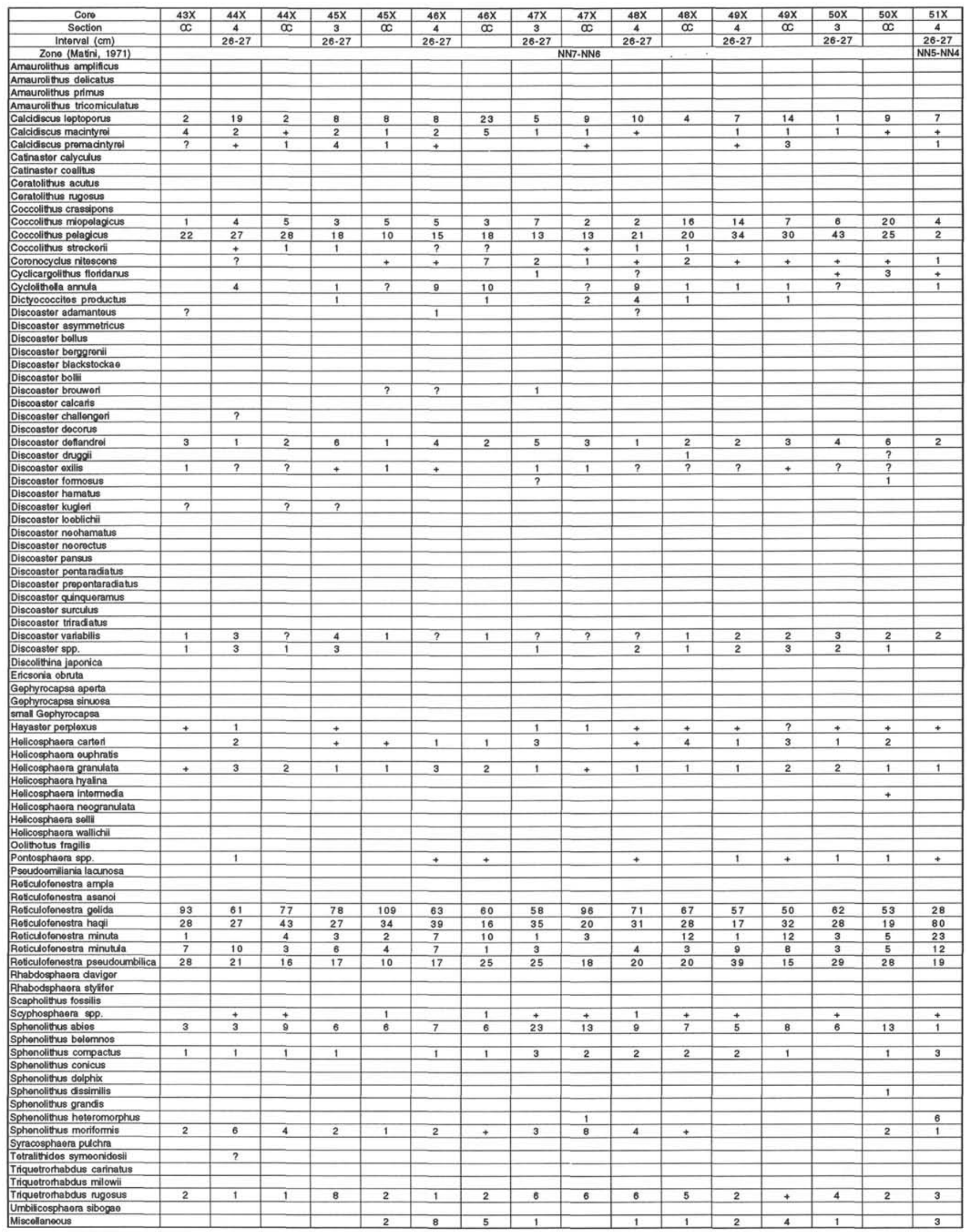


Table 14 (continued).

\begin{tabular}{|c|c|c|c|c|}
\hline Coro & $51 x$ & $52 x$ & $52 X$ & $53 \times$ \\
\hline Section & $\propto$ & 3 & $\propto$ & 2 \\
\hline Interval $(\mathrm{cm})$ & & $26 \cdot 27$ & & $26 \cdot 27$ \\
\hline Zone (Matini, 1971) & & & & \\
\hline Amaurolithus amplificus & & & & \\
\hline Amaurolithus delicatus & & & & \\
\hline Amaurolithus primus & & & & \\
\hline Amaurolithus tricomiculatus & & & & \\
\hline Calcidiscus loptoporus & 3 & 1 & 7 & 5 \\
\hline Calcidiscus macintyrol & 1 & 3 & 3 & + \\
\hline Calcidiscus premacintyroi & 1 & & 1 & \\
\hline Catinaster calyculus & & & & \\
\hline Catinastor coalitus & & & & \\
\hline Coratolithus acutus & & & & \\
\hline Ceratolithus rugosus & & & & \\
\hline Coccolithus crassipons & & & & \\
\hline Coccolithus miopelagicus & 18 & 1 & 5 & 5 \\
\hline Coccolithus polagicus & 22 & 9 & 23 & 22 \\
\hline Coccollithus strockeril & & & & \\
\hline Coronocyclus nitoscens & + & + & + & + \\
\hline Cyclicargolithus fioridanus & 7 & 44 & 27 & 38 \\
\hline Cyclolitholla annula & & & 6 & $?$ \\
\hline Dictyococcitos productus & 1 & & & 1 \\
\hline Discoastor adamantous & & 1 & & \\
\hline Discoaster asymmetricus & & & & \\
\hline Discoaster bellus & & & & \\
\hline Discoaster borggrenii & & & & \\
\hline Discoastor blackstockae & & & & \\
\hline Discoaster bolli & & & & \\
\hline Discoaster brouweri & & & & \\
\hline Discoaster calcaris & & & & \\
\hline Discoaster challengeri & & & & \\
\hline Discoaster decorus & & & & \\
\hline Discoaster deflandroi & 1 & 7 & 9 & 9 \\
\hline Discoaster druggii & $?$ & & 1 & \\
\hline Discoaster exilis & $?$ & 5 & 3 & $?$ \\
\hline Discoastor formosus & & & & \\
\hline Discoaster hamatus & & & & \\
\hline Discoaster kugleri & & & & \\
\hline Discoaster loeblichii & & & & \\
\hline Discoastor noohamatus & & & & \\
\hline Discoaster neorectus & & & & \\
\hline Discoastor pansus & & & & \\
\hline Discoaster pentaradiatus & & & & \\
\hline Discoaster propentaradiatus & & & & \\
\hline Discoaster quinqueramus & & & & \\
\hline Discoaster surculus & & & & \\
\hline Discoastor triradiatus & & & & \\
\hline Discoaster variabilis & 5 & 5 & 3 & 4 \\
\hline Discoaster spp. & 6 & 10 & 4 & 3 \\
\hline Discolithina japorica & & & & \\
\hline Ericsonia obruta & & & & \\
\hline Gephyrocapsa aperta & & & & \\
\hline Gophyrocapsa sinuosa & & & & \\
\hline smal Gephyrocapsa & & & & \\
\hline Hayaster perplexus & & + & 2 & + \\
\hline Helicosphaera cartori & 2 & + & + & 1 \\
\hline Helicosphaera euphratis & & & & \\
\hline Holicosphaema granulata & 1 & + & + & 1 \\
\hline Holicosphaera hyalina & & & & \\
\hline Helicosphaera intermedia & + & & & \\
\hline Helicosphaera neogranuiata & & & & \\
\hline Holicosphaora sollif & & & & \\
\hline Hellicosphaera wallichil & & & & \\
\hline Oolithotus fragilis & & & & \\
\hline Pontosphaera spp. & & + & + & + \\
\hline Psoudoomiliania lacunosa & & & & \\
\hline Reticulofenostra ampla & & & & \\
\hline Roticulofonestm asanol & & & & \\
\hline Roticulofenestra gelida & 38 & 9 & 34 & 4 \\
\hline Reticulofenestra haqil & 36 & 12 & & 27 \\
\hline Reticulofenestra minuta & 1 & & & 26 \\
\hline Roticulofonestra minutula & 5 & & 13 & 27 \\
\hline Retculofenestra pseudoumbilica & 16 & 28 & 12 & 10 \\
\hline Rhabdosphaora daviger & & & & \\
\hline Rhabodsphaera stylifor & & & & \\
\hline Scapholithus tossilis & & & & \\
\hline Scyphosphaera spp. & 2 & + & 1 & 1 \\
\hline Sphenolithus abies & 4 & 4 & 4 & 1 \\
\hline Sphenolithus belemnos & & & & \\
\hline Sphonolithus compactus & 2 & 2 & 4 & 1 \\
\hline Sphenolithus conicus & $?$ & 10 & 1 & + \\
\hline Sphenolithus delphix & & & & \\
\hline Sphenolithus dissimilis & & & & \\
\hline Sphenolithus grandis & & & & \\
\hline Sphenolithus heteromorphus & 13 & 37 & 18 & 10 \\
\hline Sphenolithus moritormis & 10 & 6 & 8 & 1 \\
\hline Syracosphaera pulchra & & & & \\
\hline Tetralithides symeonidesii & & & & \\
\hline Triquotrothabdus carinatus & & $?$ & & $?$ \\
\hline Triquetromabdus milowii & & & & \\
\hline Triquotrorhabdus rugosus & 3 & 6 & 4 & 3 \\
\hline Umbilicosphaera sibogao & & & & \\
\hline Miscollaneous & 2 & & 7 & \\
\hline
\end{tabular}


Table 14 (continued).

\begin{tabular}{|c|c|c|c|c|}
\hline Coro & $59 \mathrm{X}$ & $60 \mathrm{X}$ & $60 \mathrm{X}$ & $61 \mathrm{X}$ \\
\hline Section & $\propto$ & 3 & $\propto$ & 4 \\
\hline Interval $(\mathrm{cm})$ & & $26-27$ & & $26-27$ \\
\hline Zone (Matini, 1971) & & & NN5-N! & \\
\hline Amaurolithus amplificus & & & & \\
\hline Amaurolithus delicatus & & & & \\
\hline Amaurolithus primus & & & & \\
\hline Amaurolithus tricomiculatus & & & & \\
\hline Calcidiscus leptoporus & 2 & 1 & 6 & 4 \\
\hline Calcidiscus macintyroi & & 1 & & \\
\hline Calcidiscus promacintyroi & & & & \\
\hline Catinaster calyculus & & & & \\
\hline Catinastor coalitus & & & & \\
\hline Ceratolithus acutus & & & & \\
\hline Ceratolithus rugosus & & & & \\
\hline Coccollithus crassipons & & & & \\
\hline Coccolithus miopelagicus & 8 & 6 & 6 & 8 \\
\hline Coccolithus pelagicus & 16 & 33 & 39 & 14 \\
\hline Coccolithus strockoril & & & 1 & \\
\hline Coronocyclus nitoscens & + & 1 & + & + \\
\hline Cyclicargolithus floridanus & 27 & 58 & 39 & 26 \\
\hline Cyclolitholla armula & 1 & $?$ & 2 & \\
\hline Dictyococcitos productus & & & & \\
\hline Discoaster adamantous & 1 & & ? & 2 \\
\hline Discoaster asymmetricus & & & & \\
\hline Discoaster bollus & & & & \\
\hline Discoaster borggronii & & & & \\
\hline Discoastor blackstockao & & & & \\
\hline Discoaster bollii & & & & \\
\hline Discoaster brouwerí & & & & \\
\hline Discoaster calcaris & & & & \\
\hline Discoastor challongeri & & & & \\
\hline Discoaster docorus & & & & \\
\hline Discoastor doffandroi & 32 & 24 & 16 & 60 \\
\hline Discoaster dngggi & & & & $?$ \\
\hline Discoaster exilis & & & & \\
\hline Discoastor formosus & & & & \\
\hline Discoastor hamatus & & & & \\
\hline Discoaster kugleri & & & & \\
\hline Discoaster looblichil & & & & \\
\hline Discoastor noohamatus & & & & \\
\hline Discoaster nooroctus & & & & \\
\hline Discoastor pansus & & & & \\
\hline Discoaster pentaradiatus & & & & \\
\hline Discoaster propentaradiatus & & & & \\
\hline Discoaster quinquoramus & & & & \\
\hline Discoaster surculus & & & & \\
\hline Discoastor triradiatus & & & & \\
\hline Discoaster variabilis & 1 & 7 & 2 & 4 \\
\hline Discoaster spp. & 4 & 1 & 1 & 2 \\
\hline Discolittina japorica & & & & \\
\hline Enicsonia obruta & $?$ & 1 & & \\
\hline Gephyrocapsa aperta & & & & \\
\hline Gephyrocapsa sinuosa & & & & \\
\hline smal Gephyrocapsa & & & & \\
\hline Hayaster perplexus & + & + & 4 & 1 \\
\hline Helicosphaera carteri & & & + & \\
\hline Holicosphaera ouphrats & & & & \\
\hline Holicosphaora granulata & + & + & + & + \\
\hline Helicosphaera hyalina & & & & \\
\hline Helicosphaera intermedia & & & & 1 \\
\hline Holicosphaora noogranulata & & & & \\
\hline Hollicosphaora solli & & & & \\
\hline Helicosphaera wallichil & & & & \\
\hline Oolithotus fragilis & & & & \\
\hline Pontosphaora spp. & & & & + \\
\hline Pseudoemiliania lacunosa & & & & \\
\hline Robiculofenestra ampla & & & & \\
\hline Reticulofenestra asanoi & & & & \\
\hline Roticulofonestra golida & 5 & 4 & 14 & 1 \\
\hline Reticulofenestra haqii & 1 & & 4 & 9 \\
\hline Roticulofonestra minuta & 1 & & 5 & 3 \\
\hline Reticulofenestra minutula & 2 & & 4 & 16 \\
\hline Roticulofenestra psoudoumbilica & 9 & 2 & 13 & 1 \\
\hline Rhabdosphaera daviger & & & & \\
\hline Ahabodsphaera stylifer & & & & \\
\hline Scapholithus fossilis & & & & \\
\hline Scyphosphaera spp. & & + & + & \\
\hline Sphenolithus ables & & & & \\
\hline Sphenolithus belemnos & & & & \\
\hline Sphenolithus compactus & 1 & 1 & 1 & 1 \\
\hline Sphenolithus conicus & & & & \\
\hline Sphenolithus delphix & & & & \\
\hline Sphenolithus dissimilis & & & & \\
\hline Sphenolithus grandis & & & & \\
\hline Sphonolithus hotoromorphus & 14 & 10 & 11 & 6 \\
\hline Sphonolithus moriformis & 73 & 46 & 30 & 37 \\
\hline Syracosphaora pulchra & & & & \\
\hline Totralittrides symeonidesil & & & & \\
\hline Triquetrorhabdus carinatus & & & $?$ & \\
\hline Triquetrorhabdus milowil & & & & \\
\hline Triquetrothabdus rugosus & 2 & 3 & + & 2 \\
\hline Umbilicosphaera sibogae & & & & \\
\hline Miscellaneous & & 1 & 2 & 1 \\
\hline
\end{tabular}


Table 14 (continued).

\begin{tabular}{|c|c|c|c|c|}
\hline Coro & $67 X$ & $68 x$ & $68 x$ & $69 \mathrm{X}$ \\
\hline Section & $\propto$ & 1 & $\propto$ & 2 \\
\hline Interval $(\mathrm{cm})$ & & 26.27 & & $26 \cdot 27$ \\
\hline Zone (Matini, 1971) & & & & \\
\hline Amaurolithus amplificus & & & & \\
\hline Amaurolithus delicatus & & & & \\
\hline Amaurolithus primus & & & & \\
\hline Amaurolithus tricomiculatus & & & & \\
\hline Calcidiscus leptoporus & 4 & & 5 & 1 \\
\hline Calcidiscus macintyrol & + & & & \\
\hline Calcidiscus promadintyrol & & & & \\
\hline Catinaster calyculus & & & & \\
\hline Catinaster coalitus & & & & \\
\hline Coratolithus acutus & & & & \\
\hline Coratolithus rugosus & & & & \\
\hline Coccolithus crassipons & & & & \\
\hline Coccollthus miopelagicus & + & 6 & 2 & 1 \\
\hline Coccolithus polagicus & 6 & 16 & 32 & 22 \\
\hline Coccolithus streckeril & & & 1 & $?$ \\
\hline Coronocyclus nitoscons & $?$ & + & + & + \\
\hline Cyclicargolithus floridanus & 38 & 48 & 53 & 32 \\
\hline Cyclolitholla annula & & & & \\
\hline Dictyococcites productus & & & & \\
\hline Discoaster adamanteus & 2 & & 1 & \\
\hline Discoaster asymmetricus & & & & \\
\hline Discoastor bollus & & & & \\
\hline Discoaster berggrenii & & & & \\
\hline Discoastor blackstockae & & & & \\
\hline Discoaster bollii & & & & \\
\hline Discoaster brouwori & & & & \\
\hline Discoaster calcaris & & & & \\
\hline Discoaster challengeri & & & & \\
\hline Discoaster decorus & & & & \\
\hline Discoastor doflandroi & 20 & 26 & 26 & 15 \\
\hline Discoastor druggii & & & & \\
\hline Discoaster exills & & & & \\
\hline Discoastor formosus & & & & \\
\hline Discoaster hamatus & & & & \\
\hline Discoaster kugleri & & & & \\
\hline Discoaster looblichii & & & & \\
\hline Discoaster neohamatus & & & & \\
\hline Discoastor neorectus & & & & \\
\hline Discoastor pansus & & & & \\
\hline Discoaster pentaradiatus & & & & \\
\hline Discoaster prepentaradiatus & & & & \\
\hline Discoaster quinqueramus & & & & \\
\hline Discoastor surculus & & & & \\
\hline Discoaster triradiatus & & & & \\
\hline Discoaster variabilis & $?$ & 1 & + & \\
\hline Discoaster spp. & & & & \\
\hline Discolittrina japorica & & & & \\
\hline Ericsonia obruta & 2 & + & 1 & 1 \\
\hline Gephyrocapsa aperta & & & & \\
\hline Gophyrocapsa sinuosa & & & & \\
\hline mall Gephyrocapsa & & & & \\
\hline Hayaster perplexus & 1 & & & \\
\hline Helicosphaera carteri & & & & \\
\hline Helicosphaera ouphratis & & & & \\
\hline Helicosphaera granulata & $?$ & & & \\
\hline Hellicosphaora hyalina & & & & \\
\hline Helicosphaera intormedia & & & & \\
\hline Helicosphaera neogranulata & & & & \\
\hline Helicosphaera solli & & & & \\
\hline Helicosphaera wallichil & & & & \\
\hline Oolithotus fragilis & & & & \\
\hline Pontosphaera spp. & & & & \\
\hline Psoudoomiliania lacanosa & & & & \\
\hline Reticulofenestra ampla & & & & \\
\hline Reticulofonostra asanoi & & & & \\
\hline Roticulofonestra gelida & 28 & 38 & 28 & 47 \\
\hline Reticulofonestra haqii & 29 & 10 & 21 & 23 \\
\hline Reticulofenestra minuta & 9 & 3 & 3 & 1 \\
\hline Reticulofenestra minutula & 3 & & 4 & \\
\hline Reticulofonestra pseudoumbilica & 1 & 2 & 2 & 4 \\
\hline Rhabdosphaera daviger & & & & \\
\hline Rhabodsphaera styllifor & & & & \\
\hline Scapholithus fossilis & & & & \\
\hline Scyphosphaera spp. & + & & & \\
\hline Sphenolithus ablos & & & & \\
\hline Sphenolithus belemnos & & & & \\
\hline Sphonolithus compactus & 3 & + & 3 & 14 \\
\hline Sphonolithus conicus & & & & \\
\hline Sphenolithus delphix & & & & \\
\hline Sphenolithus dissimilis & 12 & 8 & 7 & 8 \\
\hline Sphenolithus grandis & & & & \\
\hline Sphenolithus heteromorphus & & & & \\
\hline Sphenolithus moritormis & 29 & 26 & 9 & 27 \\
\hline Syracosphaera pulchra & & & & \\
\hline Tetralithides symoonidesii & & & + & \\
\hline Triquetrorhabdus carinatus & 9 & 14 & + & 1 \\
\hline Triquetrorhabdus milowil & & 1 & & 1 \\
\hline Triquetrorhabdus rugosus & & & & \\
\hline Umbilicosphaora sibogao & & & & \\
\hline Miscellaneous & 4 & 1 & 2 & 2 \\
\hline
\end{tabular}


Table 14 (continued).

\begin{tabular}{|c|c|c|c|}
\hline Core & $75 X$ & $76 \mathrm{X}$ & $76 \mathrm{X}$ \\
\hline Section & $\propto$ & 2 & $\propto$ \\
\hline Interval $(\mathrm{cm})$ & & $18 \cdot 19$ & \\
\hline Zone (Matini, 1971) & & $\mathrm{NNI}$ & \\
\hline Amaurolithus amplificus & & & \\
\hline Amaurolithus delicatus & & & \\
\hline Amaurolithus primus & & & \\
\hline Amaurolithus tricomiculatu & & & \\
\hline Calcidiscus loptoporus & & & 2 \\
\hline Calcidiscus macintyroi & & & \\
\hline Galcidiscus promadintyrol & & & \\
\hline Catinaster calyculus & & & \\
\hline Catinaster coalitus & & & \\
\hline Coratolithus acutus & & & \\
\hline Ceratolithus nugosus & & & \\
\hline Coccolithus crassipons & & & \\
\hline Coccolithus miopelagicus & 4 & 3 & 4 \\
\hline Coccolithus polagicus & 4 & 5 & 5 \\
\hline Coccolithus strockenii & & & \\
\hline Coronocyclus nitoscens & 1 & & \\
\hline Cyclicargolithus floridanus & 122 & 123 & 107 \\
\hline Cyclolithella annula & & & \\
\hline Dictyococcitos productus & & & \\
\hline Discoastor adamantous & & & \\
\hline Discoaster asymmetricus & & & \\
\hline Discoaster bellus & & & \\
\hline Discoaster berggrenil & & & \\
\hline Discoaster blackstockae & & & \\
\hline Discoastor boliii & & & \\
\hline Discoastor brouwori & & & \\
\hline Discoaster calcaris & & & \\
\hline Discoaster challengerí & & & \\
\hline Discoaster decons & & & \\
\hline Discoastor deflandrol & 21 & 10 & 3 \\
\hline Discoaster druggi & & & \\
\hline Discoastor oxilis & & & \\
\hline Discoaster formosus & & & \\
\hline Discoaster hamatus & & & \\
\hline Discoaster kuglon & & & \\
\hline Discoaster looblichil & & & \\
\hline Discoaster noohamatus & & & \\
\hline Discoaster neorectus & & & \\
\hline Discoaster pansus & & & \\
\hline Discoaster pentaradiatus & & & \\
\hline Discoaster prepentaradiatu & & & \\
\hline Discoaster quinqueramus & & & \\
\hline Discoaster surculus & & & \\
\hline Discoaster triradiatus & & & \\
\hline Discoaster variabilis & 2 & $?$ & \\
\hline Discoaster spp. & & & \\
\hline Discolithina japonica & & & \\
\hline Ericsonia obruta & 3 & 1 & \\
\hline Gophyrocapsa aperta & & & \\
\hline Gephyrocapsa sinuosa & & & \\
\hline smal Gophyrocapsa & & & \\
\hline Hayaster perploxus & & & \\
\hline Helicosphaera carteri & & & \\
\hline Holicosphaera ouphratis & & & \\
\hline Helicosphaera granulata & 1 & & \\
\hline Holicosphaera hyalina & & & \\
\hline Helicosphaera intermedia & & & \\
\hline Holicosphaora noogranulata & & & \\
\hline Holicosphaora solifi & & & \\
\hline Helicosphaera wallichil & & & \\
\hline Oolithotus fragilis & & & \\
\hline Pontosphaera spp. & & & \\
\hline Psoudoemiliania lacunosa & & & \\
\hline Roticulofonestra ampla & & & \\
\hline Reticulofenestra asanoi & & & \\
\hline Reticulofonostra golida & 3 & 3 & \\
\hline Rebiculofenestra hagii & & 1 & 1 \\
\hline Reticulofonestra minuta & & & \\
\hline Reticulotenestra minutula & & & \\
\hline Roticulofonostra psoudoum & & & \\
\hline Rhabdosphaera daviger & & & \\
\hline Rhabodsphaera styifor & & & \\
\hline Scapholithus fossilis & & & \\
\hline Scyphosphaora spp. & & & \\
\hline Sphenolithus abies & & & \\
\hline Sphenolithus belemnos & & & \\
\hline Sphenolithus compactus & 1 & 3 & 2 \\
\hline Sphenolithus conicus & & & \\
\hline Sphonolithus dolphix & & $?$ & 2 \\
\hline Sphenolithus dissimillis & 6 & 4 & 6 \\
\hline Sphenolithus grandis & & & \\
\hline Sphenolithus heteromorphe & & & \\
\hline Sphonolithus moriformis & 25 & 3 & 3 \\
\hline Syracosphaera pulchra & & & \\
\hline Tetralithides symeonidesii & & & \\
\hline Triquetrorhabdus carinatus & 3 & 43 & 62 \\
\hline Triquetrorhabdus milowil & 4 & 1 & 3 \\
\hline Triquotrorhabdus nggosus & & $?$ & \\
\hline Umblicosphaera sibogao & & & \\
\hline Miscollaneous & & & \\
\hline
\end{tabular}

Table 15. Calcareous nannofossil occurrences, Hole 805C.

\begin{tabular}{|c|c|c|c|c|c|c|}
\hline Core & $4 \mathrm{H}$ & $4 \mathrm{H}$ & $5 \mathrm{H}$ & $5 \mathrm{H}$ & $6 \mathrm{H}$ & $6 \mathrm{H}$ \\
\hline Section & 5 & $\propto$ & 3 & $\propto$ & 4 & $\propto$ \\
\hline Interval $(\mathrm{cm})$ & 23.24 & & 23.24 & & 23.24 & \\
\hline Zone (Martini, 1971) & NN19 & \multicolumn{2}{|c|}{ NN18 } & \multicolumn{3}{|c|}{ NN16 } \\
\hline Calcidiscus leptoporus & 21 & 13 & 25 & 27 & 9 & 9 \\
\hline Calcidiscus macintyrei & 1 & 2 & 1 & + & + & + \\
\hline Ceratolithus rugosus & & + & + & + & & + \\
\hline Ceratolithus simplex & & & + & + & & + \\
\hline Ceratolithus telesmus & & & + & & & \\
\hline Coccolithus crassipons & + & & + & & + & + \\
\hline Coccolithus pelagicus & + & 1 & 1 & + & 4 & 1 \\
\hline Coccolithus streckerii & & & + & 1 & + & \\
\hline Cyclolithelia annula & 2 & & + & 1 & 6 & + \\
\hline Dictyococcites productus & 5 & 4 & 7 & 2 & & \\
\hline Discoaster asymmetricus & & & + & + & 2 & + \\
\hline Discoaster blackstockae & & & + & & + & \\
\hline Discoaster brouweri & & 2 & 4 & 2 & 19 & 3 \\
\hline Discoaster challengeri & & & & & & + \\
\hline Discoaster pentaradiatus & & & & 1 & 3 & + \\
\hline Discoaster surculus & & & & + & + & + \\
\hline Discoaster triradiatus & & + & & & 1 & + \\
\hline Gephyrocapsa aperta & & & & 1 & & \\
\hline small Gephyrocapsa & 30 & 2 & & 2 & & 1 \\
\hline Hayaspter perplexus & & + & + & & & \\
\hline Helicosphaera carteri & + & 2 & 2 & + & 2 & 2 \\
\hline Helicosphaera neogranulata & + & + & + & + & & + \\
\hline Helicosphaera sellii & + & + & 1 & 1 & + & + \\
\hline Helicosphaera wallichii & + & + & + & + & + & \\
\hline Oolithotus fragilis & 1 & & 1 & & + & 1 \\
\hline Pontosphaera spp. & & & & & + & \\
\hline Pseudoemiliania lacunosa & 2 & 10 & 8 & 1 & 1 & 3 \\
\hline Reticulofenestra asanoi & & + & 1 & & + & \\
\hline Reticulofenestra haqii & & & 2 & & 12 & 20 \\
\hline Reticulofenestra minuta & 113 & 118 & 97 & 123 & 91 & 82 \\
\hline Reticulotenestra minutula & 16 & 44 & 40 & 34 & 43 & 78 \\
\hline Reticulofenestra pseudoumbilica & & & + & & + & + \\
\hline Rhabdosphaera claviger & & + & 1 & & & \\
\hline Scyphosphaera spp. & & & & & 1 & 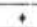 \\
\hline Syracosphaera pulchra & + & + & + & 2 & 1 & 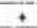 \\
\hline Tetralithides symeonidesii & 3 & & + & & + & \\
\hline Triquetrorhabdulus rugosus & & & & & + & \\
\hline Umbilicosphaera sibogae & 5 & 2 & 4 & 1 & 2 & \\
\hline Miscellaneous & 1 & & 5 & 1 & 3 & \\
\hline
\end{tabular}

Note $+=$ trace 
Table 16. Calcareous nannofossil occurrences, Hole 805B.

\begin{tabular}{|c|c|c|c|}
\hline Cone & $7 \mathrm{H}$ & $8 \mathrm{H}$ & $\mathrm{BH}$ \\
\hline Section & $\infty$ & 4 & $\infty$ \\
\hline Interval $(\mathrm{cm})$ & & $23 \cdot 24$ & \\
\hline Zone (Martini, 1971) & & NN16 & \\
\hline Amaurolithus amplificus & & & \\
\hline Amaurolithus dolicatus & & & \\
\hline Amaurolithus primus & & & \\
\hline \begin{tabular}{|l|} 
Amaurolithus tricorniculatus \\
\end{tabular} & & & \\
\hline Calcidiscus loptoporus & 12 & 16 & 24 \\
\hline Calcidiscus macintyrei & 1 & 3 & 1 \\
\hline Calcidiscus premacintyroi & & $?$ & \\
\hline Catinaster altus & & & \\
\hline Catinastor calyculus & & & \\
\hline Catinaster coalitus & & & \\
\hline Ceratolithus acutus & & & \\
\hline Ceratolithus rugosus & & + & + \\
\hline Coccolithus eopolagicus & & & \\
\hline Coccolithus miopolagicus & & & \\
\hline Coccolithus polagious & & & \\
\hline Coccolithus strockerii & & & \\
\hline Coronocyclus nitoscons & & & \\
\hline Cydicargolithus Noridanus & & & \\
\hline Cyclolithella annula & 10 & 12 & 2 \\
\hline Dictyococcites productus & 1 & & \\
\hline Discoaster adamantous & & & \\
\hline Discoaster asymmetricus & + & + & 1 \\
\hline Discoaster bellus & & & \\
\hline Diecoaster berggrenil & & & \\
\hline Discoastar blackstockae & & & \\
\hline Discoaster braarudi & & & \\
\hline Discoaster brouweri & 16 & 4 & 6 \\
\hline Discoastor calcaris & & & \\
\hline Discoaster challengerí & & & $?$ \\
\hline Discoastor docorus & & + & \\
\hline Discoaster doffandroi & & & \\
\hline Discoaster druggii & & & \\
\hline Discoaster exdlis & & & \\
\hline Discoaster formosus & & & \\
\hline Discoaster hamatus & & & \\
\hline Discoester intercalaris & & & \\
\hline Discoastor kuglori & & & \\
\hline Discoester loeblichii & & & \\
\hline Discoestor moorel & & & \\
\hline Discoastor neohamatus & & & \\
\hline Discoaster noorectus & & & \\
\hline Disconstor pansus & & & \\
\hline Discoaster pentaradiatus & & + & 2 \\
\hline Discoaster propentaradiatus & & & \\
\hline Discoastor psoudovariabilis & & & \\
\hline Discoaster quadramus & & & \\
\hline Discoaster quinqueramus & & & \\
\hline Discoastor surculus & + & + & + \\
\hline Discoastor tamalis & + & & \\
\hline Discoastor triradiatus & + & + & \\
\hline Discoaster tristellifer & & & \\
\hline Discoaster variablis & & $?$ & + \\
\hline Discoaster spp. & 1 & 1 & \\
\hline Ericsonia obruta & & & \\
\hline Gephyrocapsa aperta & & & 13 \\
\hline small Gephyrocapsa & 1 & & 2 \\
\hline Hayastor perploxus & + & + & 1 \\
\hline Holicosphaora carteri & + & + & + \\
\hline Holicosphaera granulata & & & \\
\hline Hollcosphaera intormedia & & & \\
\hline Helicosphaera neogramulata & $?$ & $?$ & \\
\hline Helicosphaera collii & $?$ & $?$ & + \\
\hline Holicosphaera wallichil & & & $?$ \\
\hline Oolithotus fragilis & & 1 & + \\
\hline Pontospheere spp. & + & + & + \\
\hline Psoudoemiliania lacunosa & + & 2 & 4 \\
\hline Roticulolonestra asand & & & \\
\hline Rebiculolenestra gelida & & + & \\
\hline Reticulofenestra haqii & 10 & 3 & 1 \\
\hline Roticulofonostra minuta & 82 & 69 & 76 \\
\hline Roticulofonestra minutula & 65 & 88 & 52 \\
\hline Reviculolonestra psoudoumbilica & + & & \\
\hline Scapholithus fossilis & & & \\
\hline Scyphosphaore spp. & & & + \\
\hline Solidopons potrao & & & \\
\hline Sphenolithus ables & & & 6 \\
\hline Sphenolithus belomnos & & & \\
\hline Sphenolithus compactus & & & \\
\hline Sphonolithus conicus & & & \\
\hline Sphenolithus delphix & & & \\
\hline Sphenolithus dissimilis & & & \\
\hline Sphenolithus grandis & & & \\
\hline Sphenolithus hotoromorphus & & & \\
\hline Sphenolithus moriformis & & & \\
\hline Syrecosphaera pulchra & + & + & \\
\hline Tetralithidos symeonidosil & & & 1 \\
\hline Triquetrorhabdus carinatus & & & \\
\hline Triquotrorhabdus milowii & & & \\
\hline Triquetrorhabdus rugosus & & & \\
\hline Umbilicosphaera sibogae & 1 & 1 & 8 \\
\hline Miscolleneous & & 2 & \\
\hline
\end{tabular}

Note: $+=$ trace and $?=$ present but questionable. 
Table 16 (continued).

\begin{tabular}{|c|c|c|c|}
\hline Core & $14 \mathrm{H}$ & $14 \mathrm{H}$ & $15 \mathrm{H}$ \\
\hline Soction & 4 & $\propto$ & 4 \\
\hline Interval (am) & $23-24$ & & $23-24$ \\
\hline Zone (Martini, 1971) & & & \\
\hline Amaurolithus amplificus & & & \\
\hline Amaurolithus delicatus & & & \\
\hline Amaurolithus primus & & & \\
\hline Amaurolithus tricorniculatus & & & \\
\hline Calcidiscus leptoporus & 24 & 6 & 12 \\
\hline Calcidiscus macintyrei & 6 & 3 & 3 \\
\hline Calcidiscus premacintyrei & + & + & \\
\hline Catinastor altus & & & \\
\hline Cabinaster calyculus & & & \\
\hline Catinaster coalitus & & & \\
\hline Ceratolithus acutus & & & \\
\hline Coratolithus rugosus & & & \\
\hline Coccolithus oopelagicus & & & \\
\hline Coccolithus miopelagicus & & & \\
\hline Coccolithus polagicus & + & 3 & \\
\hline Cocoolithus streckerii & $?$ & $?$ & \\
\hline Coronocyclus nitoscons & & $?$ & \\
\hline Cydicargolithus foridanus & & & \\
\hline Cyciolitholla annula & 3 & 1 & 3 \\
\hline Dictyococcites productus & 2 & & \\
\hline Discoaster adamanteus & & & \\
\hline Discoaster asymmetricus & $?$ & & \\
\hline Discoaster bellus & & & \\
\hline Discoaster berggrenii & + & + & + \\
\hline Discoester blackstockae & + & & \\
\hline Discoastor braanudi & & & \\
\hline Discoestor brouweri & + & + & + \\
\hline Discoaster calcaris & & & \\
\hline Discoastor challongori & & $?$ & \\
\hline Discoaster decorus & & & \\
\hline Discoaster doffandrei & & & \\
\hline Discoester druggii & & & \\
\hline Discoaster exdis & & & \\
\hline Discoaster formosus & & & \\
\hline Discoaster hamatus & & & \\
\hline Discoester intercalaris & & & $?$ \\
\hline Discoaster kugleri & & & \\
\hline Discoester loeblichii & & $?$ & \\
\hline Diecoestor moorei & & & \\
\hline Discoestor noohamatus & & & \\
\hline Discoaster neorectus & & & \\
\hline Discoester pansus & $?$ & & \\
\hline Discoestor pentaradiatus & + & + & \\
\hline Discoaster prepentaradiatus & & & \\
\hline Discoaster pseudovariabilis & & & \\
\hline Discoastor quadramus & & & \\
\hline Discoester quinqueramus & 3 & 1 & + \\
\hline Discoester surculus & + & + & + \\
\hline Discoastor tamalis & & & \\
\hline Discoaster triradiatus & + & & \\
\hline Discoestor tristelliffor & & & \\
\hline Discoaster variabilis & + & + & + \\
\hline Discoestor spp. & 2 & & 1 \\
\hline Ericsonia obruta & & & \\
\hline Gophyrocapsa aporta & & & \\
\hline small Gophyrocapsa & & & \\
\hline Hayaster perploxus & + & + & + \\
\hline Holicosphaora cartorí & 1 & 1 & + \\
\hline Holloosphaore granulata & $?$ & 2 & + \\
\hline Holicosphaera intermedia & & & \\
\hline Holicosphaera neogranulata & & & \\
\hline Holicosphaera sollii & & & \\
\hline Helicosphaera wallichii & $?$ & $?$ & $?$ \\
\hline Oolithotus fragilis & & & \\
\hline Pontosphaera spp. & + & + & \\
\hline Psoudoomilienia lacunosa & & & \\
\hline Reticulotenestra asand & $?$ & & \\
\hline Retculolenestra golida & 5 & 3 & 6 \\
\hline Rebiculofonestra haqii & 25 & 11 & 27 \\
\hline Reticulofenestra minuta & 25 & 40 & 86 \\
\hline Retculofenestra minutula & 93 & 69 & 34 \\
\hline Reticulofonostra pseudoumbilica & 3 & 5 & 1 \\
\hline Scapholithus foseilis & & & \\
\hline Scyphosphaora spp. & + & & + \\
\hline Solidopons petrae & & & \\
\hline Sphonolithus abios & 8 & 53 & 27 \\
\hline Sphenolithus belomnos & & & \\
\hline Sphendithus compactus & & & \\
\hline Sphonolithus conious & & & \\
\hline Sphenolithus dolphix & & & \\
\hline Sphonolithus dissimilis & & & \\
\hline Sphenolithus grandis & & 1 & \\
\hline Sphenolithus hoteromorphus & & & \\
\hline Sphenolithus moriformis & & 1 & \\
\hline Syracosphaera pulchra & & & \\
\hline Totralithides eymeonidesil & + & + & \\
\hline Triquetrorhabdus carinatus & & & \\
\hline Triquotrorhabdus milowii & & & \\
\hline Triquetrorhabdus rugosus & + & + & ? \\
\hline Umbilicospheera sibogae & & & \\
\hline Miscollaneous & & & \\
\hline
\end{tabular}


Table 16 (continued).

\begin{tabular}{|c|c|c|c|}
\hline Core & $22 \mathrm{H}$ & $22 \mathrm{H}$ & $23 \mathrm{H}$ \\
\hline Section & 4 & $\propto$ & 4 \\
\hline Interval $(\mathrm{cm})$ & 23.24 & & 23.24 \\
\hline Zone (Martini, 1971) & & & NII \\
\hline Amaurolithus amplificus & & & \\
\hline Amaurolithus dellcatus & & & \\
\hline Ameurolithus primus & & & \\
\hline Amaurolithus tricorniculatus & & & \\
\hline Calcidiscus leptoporus & 8 & 7 & 12 \\
\hline Calcidecus macintyrol & + & 1 & + \\
\hline Calcidiscus premacintyrei & 2 & 1 & 2 \\
\hline Catinaster altus & & & \\
\hline Catinester calyculus & & $?$ & \\
\hline Catinaster coalitus & & & \\
\hline Ceratolithus acutus & & & \\
\hline Ceratolithus rugosus & & & \\
\hline Cocoolithus oopolagicus & & & \\
\hline Coccolithus miopolagicus & & 1 & $?$ \\
\hline Cococolithus pelegicus & + & 1 & 2 \\
\hline Cocoolithus strockerii & & & \\
\hline Coronocyclus nitoscons & & & $?$ \\
\hline Cydicargolithus foridanus & & & \\
\hline Cyclolithella annula & + & $?$ & + \\
\hline Dictyococcitos productus & & & \\
\hline Discoester adamantous & & & \\
\hline Discoaster asymmetricus & & $?$ & \\
\hline Discoester bellus & & & \\
\hline Discoaster berggrenili & 1 & + & + \\
\hline Discoester blackstockae & & & \\
\hline Discoaster braarudi & & & \\
\hline Discoaster brouweri & $?$ & + & + \\
\hline Discoastor calcanis & & & \\
\hline Discoaster challongeri & & & + \\
\hline Discosestor docorus & & & \\
\hline Discoaster doflandroi & & & \\
\hline Discoester druggii & & & \\
\hline Discoester exolis & & & $?$ \\
\hline Discoaster formosus & & & \\
\hline Discoester hamatus & & & \\
\hline Discoester intercalaris & & & \\
\hline Discoaster kuglori & & & \\
\hline Discoaster loeblichil & & $?$ & \\
\hline Discosaster moorei & & & \\
\hline Discoaster neohamatus & + & $?$ & $?$ \\
\hline Discoaster neorectus & & & \\
\hline Discoaster pansus & & & \\
\hline Discoaster pentaradiatus & & $?$ & \\
\hline Discoactor prepentaradiatus & & & \\
\hline Discoester pseudovariabilis & & & \\
\hline Discoaster quadramus & & & \\
\hline Discoaster quinqueramus & + & & $?$ \\
\hline Discoastor surculus & + & $?$ & + \\
\hline Discoester tamalis & & & \\
\hline Discoaster triradiatus & & & \\
\hline Disconster tristollifer & & & \\
\hline Discoaster variablis & + & + & \\
\hline Discoester spp. & & 2 & \\
\hline Erlicsonia obruta & & & \\
\hline Gephyrocapsa aporta & & & \\
\hline small Gephyrocapse & & & \\
\hline Hayastor perploxus & 1 & + & + \\
\hline Helicosphaera carteri & + & + & 1 \\
\hline Helicosphaora granulata & + & + & $?$ \\
\hline Holcosphaera intermedia & & & \\
\hline Helicosphaora neogranulata & & & \\
\hline Holicosphaera sellii & & & \\
\hline Helicosphaora wallichii & & & $?$ \\
\hline Oolithotus fragilis & & & \\
\hline Pontosphaora spp. & & & \\
\hline Psoudoemiliania lacunosa & & & \\
\hline Rebculofonestra asand & & & \\
\hline Reticulofenestra galida & & & 1 \\
\hline Reticulofenestra haqii & 67 & 50 & 78 \\
\hline Reticulofonestra minuta & 51 & 62 & 11 \\
\hline Fobiculofonostra minutula & 25 & 25 & 16 \\
\hline Rebiculofonestre pseudoumbilica & & & \\
\hline Scaphoilthus fossilis & & & \\
\hline Scyphosphaera spp. & + & & + \\
\hline Solidopons petrao & & & \\
\hline Sphenolithus abies & 45 & 50 & 77 \\
\hline Sphenolithus belemnos & & & \\
\hline Sphondithus compactus & & & \\
\hline Sphenolithus conicus & & & \\
\hline Sphonolithus dolphix & & & \\
\hline Sphonolithus dissimilis & & & \\
\hline Sphenolithus grandis & & & \\
\hline Sphonolithus hotoromorphus & & & \\
\hline Sphonolithus moriformis & & & \\
\hline Syracosphaera pulchra & & & \\
\hline Totralithides symeonidesil & & & \\
\hline Triquetrorhabdus carinatus & & & \\
\hline Triquetrorhabodus milowii & & & \\
\hline Triquetrorhabdus rugosus & + & + & + \\
\hline Umbilicosphaora sibogao & & & \\
\hline Miscollanoous & & & \\
\hline
\end{tabular}


Table 16 (continued).

\begin{tabular}{|c|c|c|c|}
\hline Core & $30 \mathrm{x}$ & $30 x$ & $31 X$ \\
\hline Section & 3 & $\infty$ & 3 \\
\hline Interval $(\mathrm{cm})$ & $23 \cdot 24$ & & $23-24$ \\
\hline Zone (Martini, 1971) & & & NN8 \\
\hline Amaurolithus amplificus & & & \\
\hline Amaurolithus dolicatus & & & \\
\hline Amaurolithus primus & & & \\
\hline Amaurolithus tricomiculatus & & & \\
\hline Calcidiscus loptoporus & 8 & 10 & 17 \\
\hline Calcidiscus macintyroi & 12 & 7 & 6 \\
\hline Calcidiscus premacintyrol & & 3 & 1 \\
\hline Cetinaster altus & & & \\
\hline Catinaster calyculus & $?$ & & \\
\hline Catinaster coalitus & + & 1 & + \\
\hline Ceratolithus acutus & & & \\
\hline Ceratolithus rugosus & & & \\
\hline Coccolithus espelagicus & & & \\
\hline Cocoolithus miopelagicus & 1 & 1 & 4 \\
\hline Coccolithus pelegicus & 24 & 2 & 18 \\
\hline Coccolithus streckeril & & & 1 \\
\hline Coronocyclus nitoscens & & & $?$ \\
\hline Cydicargolithus floridanus & & & \\
\hline Cyclolithella annula & + & 1 & 1 \\
\hline Dictyococcitos productus & & & \\
\hline Discoester adamanteus & & & \\
\hline Discoaster asymmetricus & & & \\
\hline Discoester bollus & 3 & 1 & \\
\hline Discoester berggrenii & & & \\
\hline Discoaster blackstockae & & & \\
\hline Discoaster braanudi & & & \\
\hline Discoaster brouweri & $?$ & & \\
\hline Discoastor calcaris & + & $?$ & 1 \\
\hline Diecoester challengeri & $?$ & $?$ & $?$ \\
\hline Discoaster deconss & & & \\
\hline Discoester doflandrei & & & \\
\hline Discoester druggil & & & \\
\hline Discoaster axdlis & $?$ & + & + \\
\hline Discoaster formosus & & & \\
\hline Discoestor hamatus & + & + & \\
\hline Discoesstor intercalaris & & & \\
\hline Disooaster kuglen & & & \\
\hline Discoaster loeblichit & & & \\
\hline Discoaster moorel & & & \\
\hline Discoaster neohamatus & $?$ & & \\
\hline Discoaster noorectus & & & \\
\hline Discoaster pancws & & & \\
\hline Discoastor pontaradiatus & & & \\
\hline Discoastor propontaradiatus & & & \\
\hline Discoaster pseudovariabilis & & + & \\
\hline Discoester quadramus & & & \\
\hline Discoaster quinqueramus & & & \\
\hline Discoaster surculus & & $?$ & \\
\hline Discoastor tarmalis & & & \\
\hline Discoastor trinadiatus & & & $?$ \\
\hline Discoaster tristellifer & & & \\
\hline Discoaster variablilis & 3 & 2 & 2 \\
\hline Disconstor spp. & & & \\
\hline Ericsonia obruta & & & \\
\hline Gophyrocapsa aperta & & & \\
\hline small Gophyrocapsa & & & \\
\hline Hayaster perplexus & 1 & 3 & + \\
\hline Hellicosphaere cartert & & & + \\
\hline Helicospheera granulata & + & 1 & 1 \\
\hline Helicosphaora intormedia & & & \\
\hline Helicosphaera neogranulata & & & \\
\hline Helicosphaora sellii & & & \\
\hline Helicosphaora wallichii & & & \\
\hline Oolithotus fragilis & & & \\
\hline Pontosphaore spp. & & & \\
\hline Psoudoom liania lacunosa & & & \\
\hline Rotbculotonostra asenol & & & \\
\hline Reticulofenestra golida & 127 & 127 & 101 \\
\hline Reticulolenestra hagi & & 3 & 8 \\
\hline Reticulofonostra minute & & & \\
\hline Reticulofonostra minutula & & 1 & 8 \\
\hline Reficulofenestra peoudoumbilica & 11 & 23 & 22 \\
\hline Scapholithus toselilis & & & \\
\hline Scyphosphaere spp. & & & + \\
\hline Solidopons potrao & & & \\
\hline Sphenolithus abies & 2 & 2 & 2 \\
\hline Sphenolithus belemnos & & & \\
\hline Sphenolithus compactus & & 5 & 2 \\
\hline Sphenolithus conicus & & & \\
\hline Sphonolithus delphix & & & \\
\hline Sphonolithus dissimilis & & & \\
\hline Sphenolithus grandis & & & \\
\hline Sphenolithus hotoromorphus & & & \\
\hline Sphonolithus moriformis & 1 & & 3 \\
\hline Syracosphaere pulchra & & & \\
\hline Tetralithides symeonidesil & & & \\
\hline Triquetrorhabolus carinatus & & & \\
\hline Triquotrorhabdus milowii & & & \\
\hline Triquotrorhabdus rugosus & 5 & 3 & 1 \\
\hline Umbillocephaora sibogae & & & \\
\hline Miscollaneous & 1 & 4 & 1 \\
\hline
\end{tabular}


Table 16 (continued).

\begin{tabular}{|c|c|c|c|}
\hline Core & $38 x$ & $38 x$ & $39 \mathrm{X}$ \\
\hline Section & 3 & $\propto$ & 3 \\
\hline Interval $(\mathrm{cm})$ & 23.24 & & $23-24$ \\
\hline Zone (Martini, 1971) & & & \\
\hline Amaurolithus amplificus & & & \\
\hline Amaurolithus dolicatus & & & \\
\hline Amaurolithus primus & & & \\
\hline Amaurolithus tricorniculatus & & & \\
\hline Calcidiscus leptoporus & 1 & 2 & 3 \\
\hline Calcidiecus macintyrol & 2 & 1 & 1 \\
\hline Calcidiscus premacintyrel & 4 & 4 & 3 \\
\hline Catinester altus & & & \\
\hline Catinastor calyculus & & & \\
\hline Catinaster coalitus & & & \\
\hline Coratolithus acutus & & & \\
\hline Ceratolithus rugosus & & & \\
\hline Coccolithus sopelagicus & & & \\
\hline Cocoolithus miopolagicus & 10 & 5 & 3 \\
\hline Coccolithus polagicus & 16 & 27 & 13 \\
\hline Cocoolithus streckerii & & & \\
\hline Coronocyclus nitoscons & 3 & & + \\
\hline Cyclicargolithus foridanus & 7 & 2 & 9 \\
\hline Cyclolitholla annula & $?$ & 2 & \\
\hline Dictyococcites productus & & & \\
\hline Discoastor adamantous & & 1 & \\
\hline Discoastor asymmotricus & & & \\
\hline Discoestor bellus & & & \\
\hline Discoestor berggronil & & & \\
\hline Discoaster blackstockao & & & \\
\hline Discoaster braanudi & & & \\
\hline Discoestor brouweri & & & \\
\hline Discoaster calcaris & & & \\
\hline Discoaster challengeri & & & \\
\hline Discoester docorus & & & \\
\hline Discoaster doflandrol & 3 & 6 & 13 \\
\hline Discoastor druggii & 3 & 4 & 3 \\
\hline Discoastor exdis & 16 & 17 & 14 \\
\hline Discoastor formosus & & 1 & \\
\hline Discoastor hamatus & & & \\
\hline Discoaster intercalaris & & & \\
\hline Discoaster kugleri & & & \\
\hline Discoester loeblichif & & & \\
\hline Discoaster mooroi & & & \\
\hline Discoaster neohamatus & & & \\
\hline Discoester neorectus & & & \\
\hline Discoaster pansus & & & \\
\hline Discoaster pentarediatus & & & \\
\hline Discoaster prepentaradiatus & & & \\
\hline Discoester pseudovariabilis & & & \\
\hline Discoastor quadramus & & & \\
\hline Discoaster quinquoramus & & & \\
\hline Discoaster surculus & & & \\
\hline Discoastor tarmalis & & & \\
\hline Discoastor trifadiatus & & & \\
\hline Discoester tristellifer & & & \\
\hline Discoaster variabilis & 6 & 12 & 5 \\
\hline Discoestor spp. & 8 & 14 & 11 \\
\hline Ericsonia obruta & & 2 & \\
\hline Gophyrocapse aperta & & & \\
\hline small Gophyrocapsa & & & \\
\hline Hayaster perplexus & 1 & 3 & 1 \\
\hline Hollicosphaera carteri & + & 1 & + \\
\hline Helicospheera granulata & 2 & 1 & 1 \\
\hline Holicosphaera intermedia & & & \\
\hline Hellcospheara neogranulata & & & \\
\hline Helicosphaera sellii & & & \\
\hline Helicosphaera wallichii & & & \\
\hline Oolithotus fragilis & & & \\
\hline Pontosphaera spp. & & & \\
\hline Psoudoemiliania lacunosa & & & \\
\hline Reticulotonestra asand & & & \\
\hline Roscculofonestra golida & 20 & 4 & 2 \\
\hline Rotculofonestra haqii & 1 & 15 & 15 \\
\hline Reticulofenostra minuta & 1 & & \\
\hline Retculofonostra minutula & 41 & 12 & 31 \\
\hline Reticulofenestra pseudoumbilica & 7 & 8 & 3 \\
\hline Scapholithus fossilis & & & \\
\hline Scyphosphaere spp. & & & \\
\hline Solidopons petrae & & & \\
\hline Sphonolithus ables & 3 & 2 & 2 \\
\hline Sphonolithus belemnos & & & \\
\hline Sphenolithus compactus & 1 & 5 & 8 \\
\hline Sphenolithus conicus & 2 & 3 & 18 \\
\hline Sphenolithus dolphix & & & \\
\hline Sphenolithus dissimilis & & & \\
\hline Sphonolithus grandis & & & \\
\hline Sphenolithus heteromorphus & 31 & 26 & 22 \\
\hline Sphenolithus moritormis & 4 & 10 & 11 \\
\hline Syrecospheore pulchre & & & \\
\hline Tetrallthides symeonidesii & 2 & & \\
\hline Triquatrorhabodus carinatus & & 3 & \\
\hline Triquetrorhabdus milowii & & & 2 \\
\hline Triquetrothabdus rugosus & 5 & 6 & 5 \\
\hline Umbilicospheara sibogae & & & \\
\hline Miscolaneous & & 1 & 1 \\
\hline
\end{tabular}


Table 16 (continued).

\begin{tabular}{|c|c|c|c|}
\hline Core & $45 x$ & $46 x$ & $46 \mathrm{X}$ \\
\hline Section & $\infty$ & 3 & $\infty$ \\
\hline Interval $(\mathrm{cm})$ & & $23-24$ & \\
\hline Zono (Martíni, 1971) & & & \\
\hline Amaurolithus amplificus & & & \\
\hline Amaurolithus delicatus & & & \\
\hline Ammurolithus primus & & & \\
\hline Amaurolithus tricorniculatus & & & \\
\hline Calcidiscus loptoporus & & 4 & \\
\hline Calcidiscus macintyrei & & + & 1 \\
\hline Calcidiscus promacintyroi & 3 & 3 & 5 \\
\hline Catinastor altus & & & \\
\hline Catinester calyculus & & & \\
\hline Cabinastor coalitus & & & \\
\hline Coratolithus acutus & & & \\
\hline Ceratolithus rugosus & & & \\
\hline Coocolithus eopelagicus & & 1 & 1 \\
\hline Coccolithus miopelagicus & 14 & 6 & 10 \\
\hline Cocoolithus polagicus & 10 & 5 & 18 \\
\hline Coccolithus streckerii & & & \\
\hline Coronocyclus nitoscons & 2 & + & \\
\hline Cydicargolithus floridanus & 27 & 41 & 35 \\
\hline Cyclolitholla annula & 1 & & 1 \\
\hline Dictyococcites productus & & & \\
\hline Discoaster adamentous & & & \\
\hline Discoaster asymmetricus & & & \\
\hline Discoaster bellus & & & \\
\hline Discoaster berggronil & & & \\
\hline Discoaster blackstockae & & & \\
\hline Discoastor braarudi & & & \\
\hline Discoastor brouweri & & & \\
\hline Discoastor calcaris & & & \\
\hline Discoaster challengeri & & & \\
\hline Discoaster decorus & & & \\
\hline Discoaster dollandroi & 19 & 11 & 26 \\
\hline Diecoaster druggii & + & & \\
\hline Discoestor exdlis & + & & \\
\hline Discoaster formosus & & & \\
\hline Discoester hamatus & & & \\
\hline Discoester intercalaris & & & \\
\hline Discoaster kuglent & & & \\
\hline Discoaster looblichil & & & \\
\hline Discoaster moorol & & & \\
\hline Discoaster nooharnatus & & & \\
\hline Discoester neorectus & & & \\
\hline Discoaster pansus & & & \\
\hline Discoaster pontaradiatus & & & \\
\hline Discoastor propentaradiatus & & & \\
\hline Discoaster psoudovariabilis & & & \\
\hline Discoastor quadramus & & & \\
\hline Discoester quinqueramus & & & \\
\hline Discoastor surculus & & & \\
\hline Discoastor tamalis & & & \\
\hline Discoester tríradiatus & & & \\
\hline Discoaster tristellifor & & & \\
\hline Discoestor variablilis & 4 & $?$ & 4 \\
\hline Discoester epp. & 1 & & \\
\hline Ericsonia obruta & 5 & 4 & 3 \\
\hline Gephyrocapsa aporta & & & \\
\hline small Gophyrocapsa & & & \\
\hline Hayastor porploxus & 1 & + & + \\
\hline Holicosphaera carteri & & & \\
\hline Holicosphaora granulata & & & \\
\hline Helicosphaera intermedia & & & \\
\hline Helicosphaere neogranulata & & & \\
\hline Holicosphaora solli & & & \\
\hline Holiossphaora wallichil & & & \\
\hline Oolithotus fragilis & & & \\
\hline Pontosphaora spp. & & 1 & + \\
\hline Psoudoomiliania lacunosa & & & \\
\hline Rebiculotonostre asand & & & \\
\hline Reticulotonostra golida & 27 & 37 & 31 \\
\hline Robiculofonostra haqui & 13 & 22 & 15 \\
\hline Reticulofenestre minuta & & 4 & 1 \\
\hline Reticulolenestra minutula & 9 & & 1 \\
\hline Roticulofenostra psoudoumbilica & 9 & 5 & 3 \\
\hline Scapholithus fossilis & & & \\
\hline Scyphosphaora spp. & & & \\
\hline Solidopons potreo & & & \\
\hline Sphenolithus abios & & & \\
\hline Sphenolithus belemnos & & & \\
\hline Sphendithus compactus & 14 & 8 & 4 \\
\hline Sphenolithus conicus & & & \\
\hline Sphenolithus delphix & & & \\
\hline Sphenolithus dissimilis & 3 & + & 6 \\
\hline Sphenolithus grandis & & & \\
\hline Sphenolithus hotoromompus & & & \\
\hline Sphenolithus moriformis & 18 & 32 & 17 \\
\hline Syracosphaora pulchra & & & \\
\hline Totralithidos symeonidosil & 1 & & \\
\hline Triquetrorhabdus carinatus & 17 & 15 & 17 \\
\hline Triquetrorhabdus milowif & & & 1 \\
\hline Triquetrorhabdus rugosus & 2 & & + \\
\hline Umbilicosphaore sibogae & & & \\
\hline Miscollanoous & & 1 & \\
\hline
\end{tabular}


Table 17. Calcareous nannofossil occurrences, Hole 804C.

\begin{tabular}{|c|c|c|c|c|c|c|c|c|c|c|c|}
\hline Core & $3 \mathrm{H}$ & $4 \mathrm{H}$ & $4 \mathrm{H}$ & $5 \mathrm{H}$ & $5 \mathrm{H}$ & $6 \mathrm{H}$ & $6 \mathrm{H}$ & $7 \mathrm{H}$ & $7 \mathrm{H}$ & $8 \mathrm{H}$ & $8 \mathrm{H}$ \\
\hline Section & $\propto$ & 3 & $\infty$ & 4 & $\infty$ & 3 & $\infty$ & 4 & $\infty$ & 3 & $\infty$ \\
\hline Interval $(\mathrm{cm})$ & & 90.91 & & 90.91 & & 90.91 & & $90-91$ & & 90.91 & \\
\hline Zone (Martini, 1971) & NN18 & NN17 & NN16 & NN15. & NN13 & & & NN1 & & & \\
\hline Amaurolithus primus & & & & & & $?$ & & & & & \\
\hline Calcidiscus leptoporus & 20 & 13 & 13 & 27 & 17 & 12 & 25 & 16 & 12 & 17 & 26 \\
\hline Calcidiscus macintyrei & + & 5 & + & 2 & 2 & 3 & 5 & 1 & 1 & 1 & + \\
\hline Calcidiscus premacintyrei & & & & & & 1 & 3 & 4 & + & 1 & 3 \\
\hline Catinaster calyculus & & & & & & & & & & & \\
\hline Catinaster coalitus & & & & & & & & & & & \\
\hline Ceratolithus cristatus & + & & + & & & & & & & & \\
\hline Ceratolithus rugosus & + & + & & 2 & + & & & & & & \\
\hline Coccolithus crassipons & + & + & & & & & & & & & \\
\hline Coccolithus eopelagicus & & & & & & & & & & & \\
\hline Coccolithus miopelagicus & & & & & & & & $?$ & $?$ & + & + \\
\hline Cocoolithus pelagicus & 1 & + & + & $?$ & & 7 & 7 & + & 3 & 11 & 6 \\
\hline Coccolithus streckenii & & & & & & & & & $?$ & & + \\
\hline Coronocyclus nitescens & & & & & & & & & $?$ & & \\
\hline Cyclicargolithus floridanus & & & & & & & & & & & \\
\hline Cyclolithella annula & $?$ & $?$ & + & $?$ & 1 & + & 1 & 1 & 3 & + & 5 \\
\hline Dictyococcites productus & 5 & & 2 & 1 & & 2 & 3 & & 1 & 1 & 1 \\
\hline Discoaster adamanteus & & & & & & & & & & & $?$ \\
\hline Discoaster asymmetricus & $?$ & + & 1 & $?$ & & $?$ & $?$ & & $?$ & & \\
\hline Discoaster bellus & & & & & & & & & & & $?$ \\
\hline Discoaster berggrenii & & & & & & $?$ & + & + & + & + & $?$ \\
\hline Discoaster blackstockae & & & & $?$ & 1 & & & & & & + \\
\hline Discoaster bollii & & & & & & & & & & & \\
\hline Discoaster braarudii & & & & & & & & & & & \\
\hline Discoaster brouweri & 3 & 4 & 5 & 3 & 3 & 6 & + & + & + & 2 & + \\
\hline Discoaster calcaris & & & & & & & & & & & \\
\hline Discoaster challengeri & & & + & $?$ & $?$ & 1 & + & $?$ & + & & $?$ \\
\hline Discoaster decorus & & & & 1 & & & & & & & \\
\hline Discoaster deflandrei & & & & $?$ & & & & & & & \\
\hline Discoaster druggii & & & & & & & & & & & \\
\hline Discoaster oxilis & & & & & & & & & & & \\
\hline Discoaster hamatus & & & & & & & & & & & \\
\hline Discoaster kuglen & & & & & & & & & & & \\
\hline Discoaster loeblichii & & & & & & & & & & & + \\
\hline Discoaster neohamatus & & & & & & & & & + & 1 & $?$ \\
\hline Discoaster neorectus & & & & & & $?$ & + & + & & + & $?$ \\
\hline Discoaster pansus & & & & $?$ & $?$ & & & $?$ & + & + & + \\
\hline Discoaster pentaradiatus & & 1 & + & 4 & 3 & & & + & + & & + \\
\hline Discoaster prepentaradiatus & & & & & & & & & & & \\
\hline Discoaster pseudovariabilis & & & & & & & & & & & \\
\hline Discoaster quadramus & & & & & & + & & & & & \\
\hline Discoaster quinqueramus & & & & + & & + & + & + & + & 2 & $?$ \\
\hline Discoaster surculus & $?$ & $?$ & + & + & $?$ & 3 & 1 & + & + & + & \\
\hline Discoaster tamalis & & & $?$ & & & & & & & & \\
\hline Discoaster triradiatus & + & + & + & + & $?$ & $?$ & + & & & $?$ & \\
\hline Discoaster tristellifer & & & & + & & & & & & & \\
\hline Discoaster variabilis & & & 1 & $?$ & 1 & + & 1 & + & + & 1 & + \\
\hline Discoaster spp. & & & & 2 & 1 & & & & & & \\
\hline Ericsonia obruta & & & & & & & & & & & \\
\hline Hayaster perplexus & + & & & 1 & & & & + & & & + \\
\hline Helicosphaera carteri & + & & + & & + & 1 & 1 & + & + & 1 & 2 \\
\hline Helicosphaera granulata & & & & & & & $?$ & + & + & + & + \\
\hline Helicosphaera neogranulata & & & + & & & & & & & & \\
\hline Helicosphaera recta & & & & & & & & & & & \\
\hline Helicosphaera sollii & 1 & + & $?$ & $?$ & & & & & & & \\
\hline Helicosphaera wallichii & + & & $?$ & & & & & & & & \\
\hline Pontosphaera spp. & & & & & & & + & + & & & \\
\hline Psoudoemiliania lacunosa & 5 & & + & & & $?$ & & & & & \\
\hline Retculofenestra asanoi & 3 & 2 & $?$ & & 1 & & & & & & \\
\hline Retcculofenestra gelida & & & & 3 & 15 & 22 & 16 & 1 & & & \\
\hline Retculofenestra haqil & & 1 & & & 4 & 39 & 10 & 65 & 26 & 36 & 20 \\
\hline Reticulofenestra minuta & 150 & 66 & 159 & 130 & 113 & 38 & 71 & 12 & 84 & 72 & 32 \\
\hline Reticulofenestra minutula & 10 & 106 & 17 & 5 & 15 & 43 & 10 & 37 & 33 & 28 & 21 \\
\hline Reticulofenestra pseudoumbilica & & + & + & 11 & 12 & 10 & 9 & 4 & 2 & & \\
\hline Scyphosphaere spp. & & & & & & & + & + & & 1 & 1 \\
\hline Sphenolithus abies & & & $?$ & 7 & 10 & 11 & 37 & 58 & 35 & 24 & 81 \\
\hline Sphenolithus belemnos & & & & & & & & & & & \\
\hline Sphenolithus diperoensis & & & & & & & & & & & \\
\hline Sphenolithus compactus & & & & & & & & & & & \\
\hline Sphenolithus conicus & & & & & & & & & & & \\
\hline Sphenolithus delphix & & & & & & & & & & & \\
\hline Sphenolithus dissimilis & & & & & & & & & & & \\
\hline Sphenolithus distentus & & & & & & & & & & & \\
\hline Sphenolithus heteromorphus & & & & & & & & & & & \\
\hline Sphenolithus moriformis & & & & & & & & & + & + & 1 \\
\hline Syracosphaera pulchra & 1 & 2 & & & & & & & & & \\
\hline Tetralithides symeonidesii & 1 & $\begin{array}{l}+ \\
\end{array}$ & & 1 & & & & + & & & + \\
\hline Triquetrorhabdus carinatus & & & & & & & & & & & \\
\hline Triquetrorhabdus milowii & & & & & & & & & & & \\
\hline Triquetrothabdus rugosus & & & & & $?$ & + & + & 1 & + & 1 & 1 \\
\hline Umbillicosphaera sibogae & & & 2 & & & & & & & & \\
\hline Zygrhablithus blijugatus & & & & & & & & & & & \\
\hline Miscellaneous & & & & & 1 & 1 & & & & & \\
\hline
\end{tabular}


Table 17 (continued).

\begin{tabular}{|c|c|c|c|c|c|c|c|c|c|c|c|}
\hline Core & $12 \mathrm{H}$ & $12 \mathrm{H}$ & $13 \mathrm{H}$ & $13 \mathrm{H}$ & $14 \mathrm{X}$ & $14 \mathrm{X}$ & $15 \mathrm{X}$ & $15 \mathrm{X}$ & $16 \mathrm{X}$ & $16 \mathrm{X}$ & $17 X$ \\
\hline Section & 3 & $\infty$ & 3 & $\infty$ & 2 & $\infty$ & 2 & $\infty$ & 1 & $\infty$ & 3 \\
\hline Interval $(\mathrm{cm})$ & 90.91 & & $90-91$ & & 90.91 & & $90-81$ & & $90-91$ & & $90-91$ \\
\hline Zone (Martini, 1971) & & NN10 & & & & & NI & & & & \\
\hline Amaurolithus primus & & & & & & & & & & & \\
\hline Calcidiscus leptoporus & 9 & 20 & 12 & 15 & 21 & 6 & 7 & 18 & 6 & 4 & 6 \\
\hline Calcidiscus macintyrei & 7 & 8 & 16 & 5 & 4 & 12 & 9 & 17 & 15 & 3 & 10 \\
\hline Calcidiscus premacintyrei & 1 & 2 & 1 & + & 1 & 4 & & 2 & & & \\
\hline Catinaster calyculus & & + & & + & + & + & & 1 & & & \\
\hline Catinaster coalitus & + & + & & & & + & & & 3 & 2 & \\
\hline Ceratolithus cristatus & & & & & & & & & & & \\
\hline Ceratolithus rugosus & & & & & & & & & & & \\
\hline Cocoolithus crassipons & & & & & & & & & & & \\
\hline Coccolithus eopelagicus & & & & & & & & & & & \\
\hline Cocoolithus miopelagicus & 3 & 1 & $?$ & 1 & 5 & 4 & 8 & 1 & 9 & 3 & 3 \\
\hline Coccolithus pelagicus & 19 & 11 & 21 & 13 & 4 & 5 & 19 & 9 & 14 & 7 & 18 \\
\hline Coccolithus streckerii & & $?$ & $?$ & $?$ & $?$ & 1 & & & $?$ & & \\
\hline Coronocyclus nitescens & & 1 & & & + & & & & & & \\
\hline Cyclicargolithus floridanus & & & & & & & & & & & \\
\hline Cyclolithella annula & + & + & + & 1 & 1 & 3 & & & $?$ & & 2 \\
\hline Dictyococcites productus & & & & & & & & & & & 2 \\
\hline Discoaster adamantous & & & & & 1 & & & & & & \\
\hline Discoaster asymmetricus & & & & & & & & & & & \\
\hline Discoaster bellus & 1 & 1 & 1 & 1 & 2 & 1 & $?$ & 2 & $?$ & & $?$ \\
\hline Discoaster berggrenii & & & & & & & & & & & \\
\hline Discoaster blackstockae & & & & & & & & & & & \\
\hline Discoaster bolliti & & & & & & & & + & $?$ & & \\
\hline Discoaster braarudii & $?$ & & 1 & & & & 2 & & & & \\
\hline Discoaster brouweri & 1 & 1 & $?$ & 4 & 1 & 1 & 8 & & & & \\
\hline Discoaster calcaris & $?$ & + & & + & + & 1 & 16 & + & 1 & 2 & \\
\hline Discoaster challengeñ & 2 & 2 & + & 2 & 2 & 3 & 1 & 2 & 2 & 1 & + \\
\hline Discoaster decorus & & & & & & & & & & & \\
\hline Discoaster deflandrel & $?$ & $?$ & & & & & & & + & & + \\
\hline Discoaster druggi & & & & & & & & & & & \\
\hline Discoaster exilis & 2 & $?$ & & 1 & $?$ & 1 & & & & 18 & 1 \\
\hline Discoaster hamatus & + & + & & 5 & 3 & 2 & + & 5 & 2 & 5 & \\
\hline Discoaster kugleni & & & & & & & & & & & \\
\hline Discosaster loeblichil & & & & & & & & & & & \\
\hline Discoaster neohamatus & 1 & + & + & 2 & 3 & + & 1 & & & & \\
\hline Discoaster neorectus & & & & & & & & & & & \\
\hline Oiscoaster pansus & $?$ & & & $?$ & & $?$ & & $?$ & $?$ & & $?$ \\
\hline Discoaster pentaradiatus & & & & & & & & & & & \\
\hline Discoaster prepentaradiatus & $?$ & $?$ & 1 & $?$ & + & $?$ & + & + & $?$ & & $?$ \\
\hline Discoaster pseudovariabilis & & & & & & $?$ & & & & 1 & \\
\hline Discoaster quadramus & & & & & & & & & & & \\
\hline Discoaster quinqueramus & & & & & & & & & & & \\
\hline Discoaster surculus & 2 & & & & & & $?$ & & & & \\
\hline Discoaster tamalis & & & & & & & & & & & \\
\hline Discoaster triradiatus & $?$ & $?$ & & & & $?$ & & $?$ & & & \\
\hline Discosster tristellifer & & & & & & & & & & & \\
\hline Discoaster variabilis & 4 & 7 & 2 & 1 & 3 & 4 & 6 & 4 & 3 & 6 & 4 \\
\hline Discoaster spp. & 3 & 2 & 4 & 1 & 4 & 2 & 9 & 1 & & 11 & 2 \\
\hline Ericsonia obruta & & & & & & & & & & & \\
\hline Hayaster perplexus & & & & 2 & & & & & & & \\
\hline Helicosphaera carterí & 1 & & & 1 & 1 & + & & & & & \\
\hline Helicosphaera granulata & 1 & 1 & & + & 3 & 2 & & & & & 3 \\
\hline Helicosphaera neogranulata & & & & & & & & & & & \\
\hline Helicosphaera recta & & & & & & & & & & & \\
\hline Helicosphaera sellii & & & & & & & & & & & \\
\hline Helicosphaera wallichii & & & & & & & & & & & \\
\hline Pontosphaera spp. & & & & & & + & & & & & 1 \\
\hline Pseudoemiliania lacunosa & & & & & & & & & & & \\
\hline Reticulofenestra asanol & & & & & & & & & & & \\
\hline Retculofenestra gelida & 91 & 110 & 47 & 101 & 87 & 123 & 77 & 97 & 109 & 99 & 65 \\
\hline Reticulofenestra hagil & 12 & 3 & 6 & 1 & 2 & 2 & 2 & 1 & 2 & & 24 \\
\hline Reticulofenestra minuta & & & & & & & & & & & 3 \\
\hline Reticulofenestra minutula & 2 & 3 & 4 & 1 & 5 & & & & 2 & 1 & 8 \\
\hline Retculofenestra pseudoumbilica & 33 & 16 & 44 & 13 & 14 & 12 & 25 & 33 & 27 & 28 & 35 \\
\hline Scyphosphaera spp. & + & + & & 1 & 1 & & & & & & \\
\hline Sphenolitthus ables & 2 & 5 & 31 & 12 & 19 & 5 & 5 & 3 & & & 2 \\
\hline Sphenolithus belemnos & & & & & & & & & & & \\
\hline Sphenolithus ciperoensis & & & & & & & & & & & \\
\hline Sphenolithus compactus & & 2 & + & 6 & 5 & 1 & & 2 & + & & 4 \\
\hline Sphenolithus conicus & & & & & & & & & & & \\
\hline Sphenolithus delphix & & & & & & & & & & & \\
\hline Sphenolithus dissimilis & & & & & & & & & & & \\
\hline Sphenolithus distentus & & & & & & & & & & & \\
\hline Sphenolithus heteromorphus & & & & & & & & & & & \\
\hline Sphenolithus moriformis & & & 5 & 4 & 7 & 1 & & + & + & 1 & 1 \\
\hline Syracosphaera pulchra & & & & & & & & & & & \\
\hline Tetralithides symeonidesii & & & & & & & & & & & \\
\hline Triquetrorhabdus carinatus & & & & & & & & & & & \\
\hline Triquetrorhabdus milowii & & & & & & & & & & & \\
\hline Triquetromabous rugosus & 3 & 4 & 4 & 2 & 1 & 3 & 5 & 2 & 4 & 6 & 5 \\
\hline Umbilicosphaera sibogae & & & & & & & & & & & \\
\hline Zygrhablithus bijugatus & & & & & & & & & & & \\
\hline Miscellaneous & & & & 4 & & 1 & & & 1 & 2 & 1 \\
\hline
\end{tabular}




\begin{tabular}{|c|c|c|c|c|c|c|c|c|c|c|c|}
\hline Core & $22 x$ & $23 x$ & $23 \mathrm{X}$ & $24 X$ & $24 X$ & $25 \mathrm{X}$ & $25 X$ & $26 \mathrm{X}$ & $26 \mathrm{X}$ & $27 X$ & $27 \mathrm{X}$ \\
\hline Section & $\infty$ & 3 & $\infty$ & 2 & $\propto$ & 3 & $\infty$ & 3 & $\infty$ & 3 & $\infty$ \\
\hline Interval $(\mathrm{cm})$ & & $90-91$ & & $80-91$ & & 94.95 & & 90.91 & & $90-91$ & \\
\hline Zone (Martini, 1971) & NN5-4 & & & & & $\mathrm{NI}$ & & & & & NN1 \\
\hline Amaurolithus primus & & & & & & & & & & & \\
\hline Calcidiscus leptoporus & & 1 & & 2 & 1 & & 1 & 4 & 2 & 1 & \\
\hline Calcidiscus macintyrei & $?$ & & 2 & 1 & & & 2 & 2 & & & \\
\hline Caldidiscus premacintyrei & & 3 & 3 & 4 & 2 & 1 & 1 & 2 & 3 & 9 & \\
\hline Catinaster calyculus & & & & & & & & & & & \\
\hline Catinaster coalitus & & & & & & & & & & & \\
\hline Ceratolithus cristatus & & & & & & & & & & & \\
\hline Ceratolithus rugosus & & & & & & & & & & & \\
\hline Coccolithus crassipons & & & & & & & & & & & \\
\hline Coccolithus eopelagiars & & & & & & & & & & & \\
\hline Coccolithus miopelagicus & 5 & 3 & 1 & 4 & 1 & 3 & 2 & 5 & 2 & + & + \\
\hline Cocoolithus pelagicus & 15 & 11 & 11 & 2 & 14 & 15 & 34 & 11 & 5 & 4 & 22 \\
\hline Coccolithus streckerii & & & & & & & & & & & \\
\hline Coronocydus nitescens & 3 & + & & & & 5 & + & + & 2 & + & \\
\hline Cyclicargolithus foridanus & 55 & 51 & 8 & 20 & 23 & 29 & 50 & 114 & 105 & 120 & 49 \\
\hline Cyclolithella annula & & & & & & & & & & & \\
\hline Dictyococcites productus & & & & & & & & & & & \\
\hline Discoester adamanteus & & & & & & & & & & $?$ & \\
\hline Discoaster asymmetricus & & & & & & & & & & & \\
\hline Discoaster bellus & & & & & & & & & & & \\
\hline Discoaster berggrenii & & & & & & & & & & & \\
\hline Discoaster blackstockae & & & & & & & & & & & \\
\hline Discoaster bollii & & & & & & & & & & & \\
\hline Discoaster braarudii & & & & & & & & & & & \\
\hline Discoaster brouweri & & & & & & & & & & & \\
\hline Discoaster calcaris & & & & & & & & & & & \\
\hline Discoaster challengeri & & & & & & & & & & & \\
\hline Discoaster decorus & & & & & & & & & & & \\
\hline Discoaster deflandrei & 65 & 60 & 18 & 10 & 4 & 19 & 7 & 9 & 4 & 4 & 27 \\
\hline Discoaster druggii & & 5 & $?$ & & + & & 1 & 1 & + & + & \\
\hline Discoaster exdilis & $?$ & & & & & & & & & & \\
\hline Discoaster hamatus & & & & & & & & & & & \\
\hline Oiscoaster kugleri & & & & & & & & & & & \\
\hline Discoaster loeblichii & & & & & & & & & & & \\
\hline Discoaster neohamatus & & & & & & & & & & & \\
\hline Discosster neorectus & & & & & & & & & & & \\
\hline Discoaster pansus & & & & & & & & & & & \\
\hline Discoaster pentaradiatus & & & & & & & & & & & \\
\hline Discoaster prepentara diatus & & & & & & & & & & & \\
\hline Discoaster pseudovariabilis & & & & & & & & & & & \\
\hline Discoaster quadramus & & & & & & & & & & & \\
\hline Discoaster quinqueramus & & & & & & & & & & & \\
\hline Discoaster surculus & & & & & & & & & & & \\
\hline Discosster tamalis & & & & & & & & & & & \\
\hline Discoaster triradiatus & & & & & & & & & & & \\
\hline Discoaster tristellifer & & & & & & & & & & & \\
\hline Discoaster variabilis & 2 & 6 & 1 & & 2 & 3 & 1 & & & & 5 \\
\hline Discoaster spp. & 2 & 13 & 1 & & & 1 & & 1 & & & 2 \\
\hline Ericsonia obruta & & & 5 & 4 & 2 & 3 & 3 & 4 & 4 & 2 & \\
\hline Hayaster perplexus & & & 1 & & + & & & & & & \\
\hline Helicosphaera carterí & & & & & & & & & & & \\
\hline Helicosphaera granulata & & & & & & & & & & & \\
\hline Hellcosphaera neogranulata & & & & & & & & & & & \\
\hline Helicosphaera recta & & & & & & & & & & & \\
\hline Helicosphaera sellii & & & & & & & & & & & \\
\hline Helcosphaera wallichii & & & & & & & & & & & \\
\hline Pontosphaera spp. & & & & 1 & & & & & & & \\
\hline Psoudoemiliania lacunosa & & & & & & & & & & & \\
\hline Reticulofenestra asanoi & & & & & & & & & & & \\
\hline Restculofenestra gelida & & 2 & 41 & 41 & 41 & 31 & 31 & 4 & 8 & 5 & \\
\hline Reticulofenestra haqii & & & 28 & 39 & 29 & 17 & 14 & 2 & 2 & 2 & \\
\hline Reticulofenestra minuta & & & & & 5 & & & & & & 1 \\
\hline Reticulofenestra minutula & 1 & & 16 & 2 & 6 & 7 & & & & + & \\
\hline Reticulofenestra psoudoumbilica & 2 & 3 & 7 & 6 & 4 & 12 & 6 & & 1 & & \\
\hline Scyphosphaera spp. & & & & & & & & & & & \\
\hline Sphenolithus abies & & 1 & 3 & 3 & 1 & & & & & & \\
\hline Sphenolithus belemnos & & & & & & & & & & & \\
\hline Sphenolithus diperoensis & & & & & & & & & & & \\
\hline Sphenolithus compactus & 4 & 3 & 20 & 14 & 16 & 16 & 20 & 12 & 7 & 5 & 1 \\
\hline Sphenolithus conious & & & & & & & & & & & \\
\hline Sphenolithus delphix & & & & & & 1 & & & 2 & + & \\
\hline Sphenolithus dissimilis & 5 & 1 & 4 & 1 & 6 & 7 & 7 & 3 & + & 2 & 3 \\
\hline Sphenolithus distentus & & & & & & & & & & & \\
\hline Sphenolithus heteromorphus & 8 & & & & & & & & & & \\
\hline Sphenolithus moriformis & 22 & 8 & 21 & 19 & 23 & 19 & 13 & 12 & 5 & 3 & 6 \\
\hline Syracosphaera pulchra & & & & & & & & & & & \\
\hline Totralithides symeonidesii & + & & & & & & & & & & \\
\hline Triquatrorhabdus carinatus & 1 & 23 & 4 & 8 & 13 & 10 & 4 & 13 & 46 & 43 & 84 \\
\hline Triquetrorhabdus milowii & 4 & 1 & & 1 & & & 1 & & 1 & & \\
\hline Triquetrorhabdus rugosus & 3 & 4 & & 6 & 1 & & & 1 & & & \\
\hline Umbilicosphaera sibogae & & & & & & & & & & & \\
\hline Zygrinablithus bijugatus & & & & & & & & & & & \\
\hline Miscollaneous & 2 & 1 & 5 & 11 & 6 & 1 & 2 & & 1 & & \\
\hline
\end{tabular}



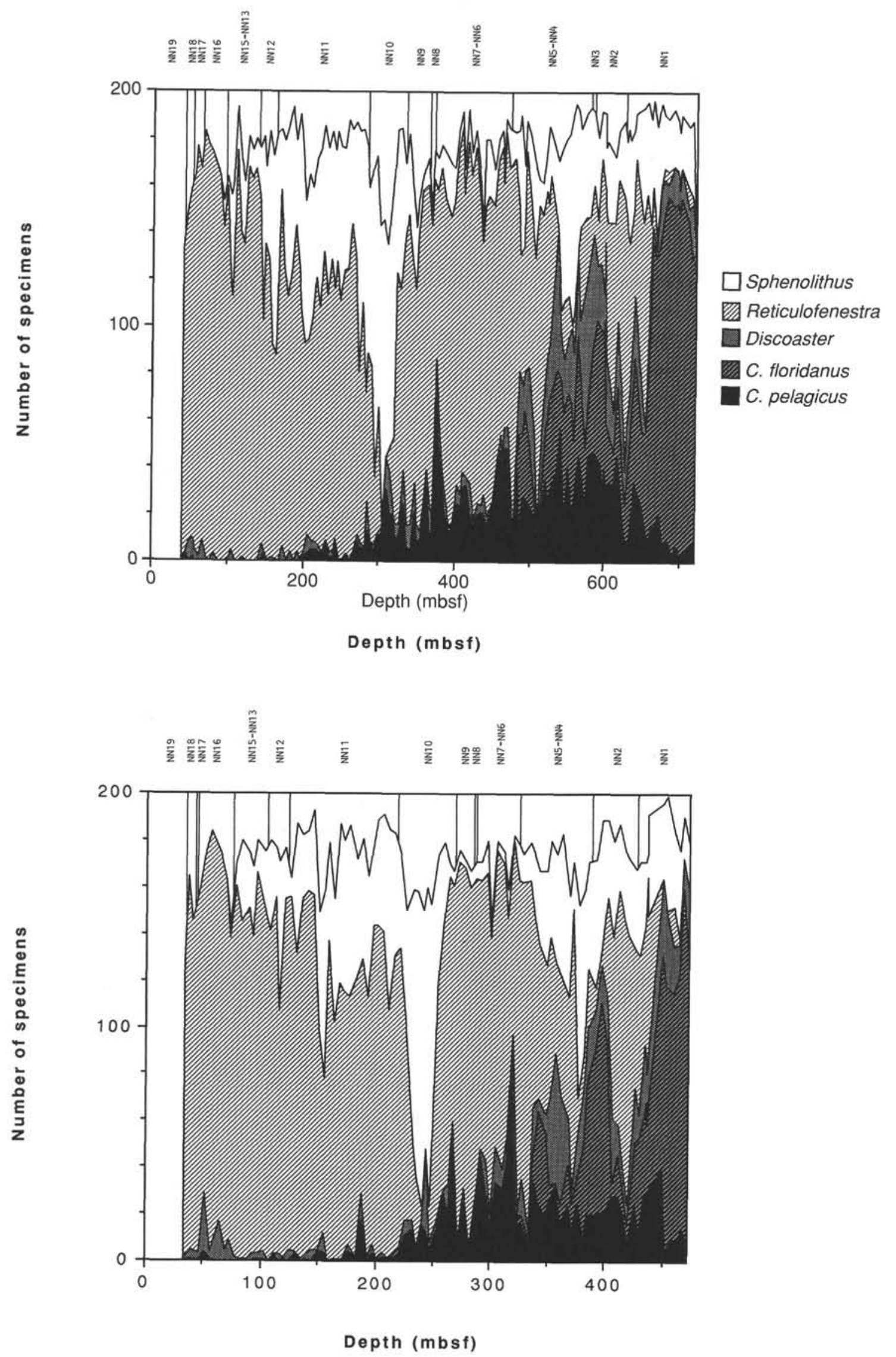

Figure 4. Sequential changes of composition of flora in Holes 806B (A), 805B and 805C (B), and 804C (C). 
T. TAKAYAMA

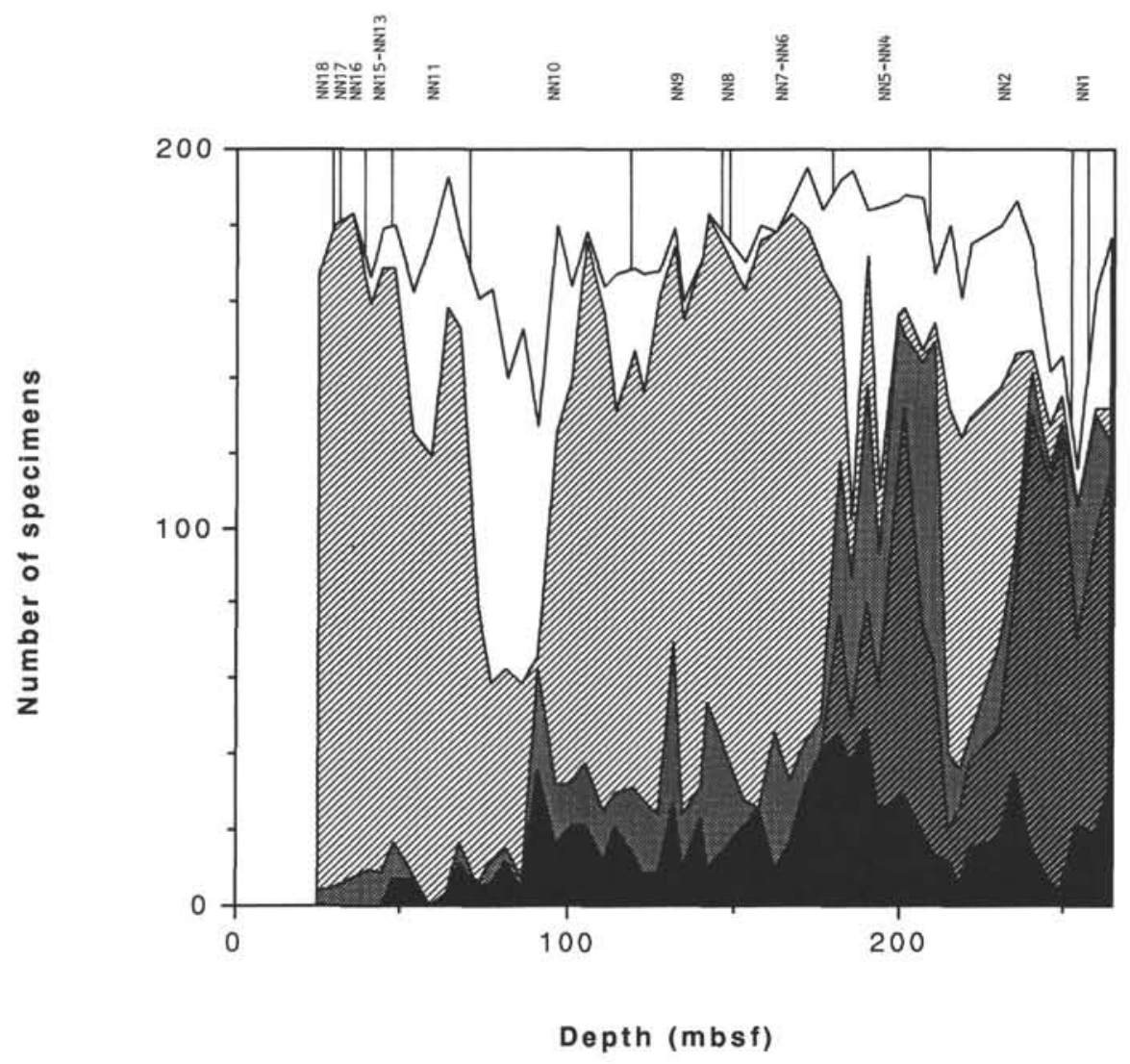

Figure 4 (continued). 
A

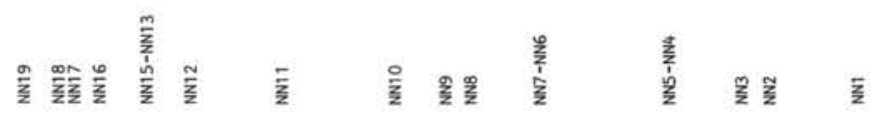

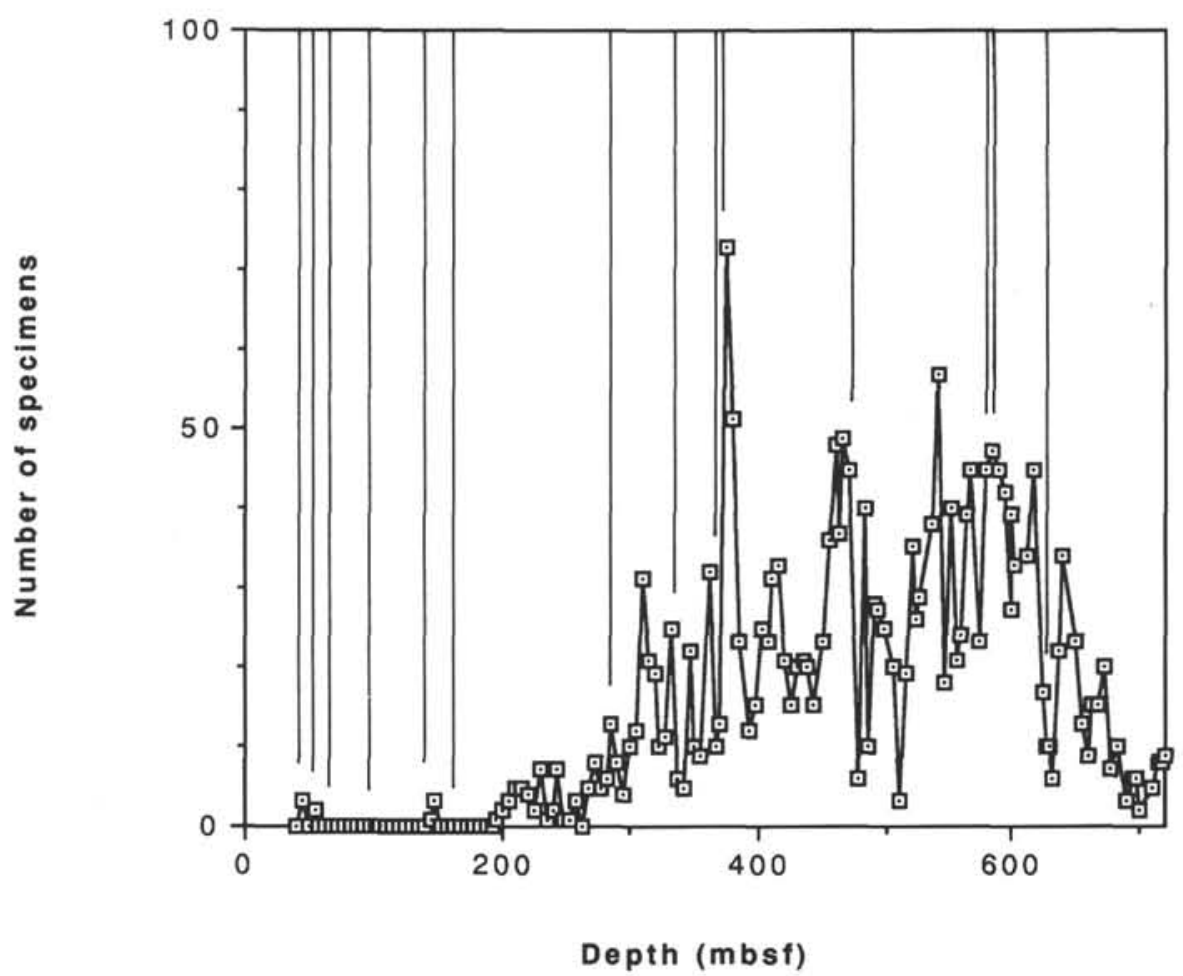

B
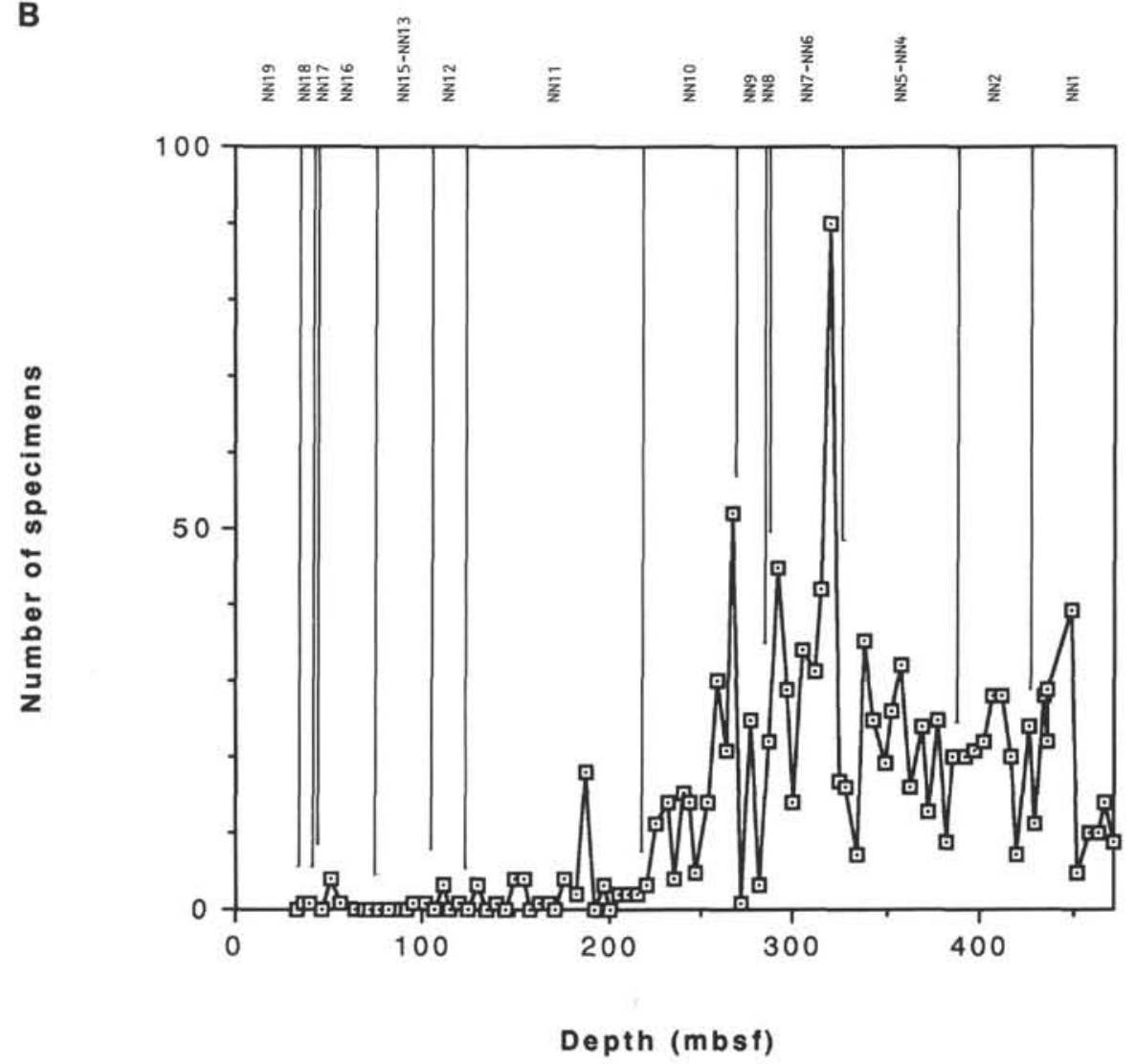

Figure 5. Sequential changes of relative abundance of Coccolithus pelagicus and C. miopelagicus in Holes 806B (A), 805B and 805C (B), and 804C (C). 
T. TAKAYAMA

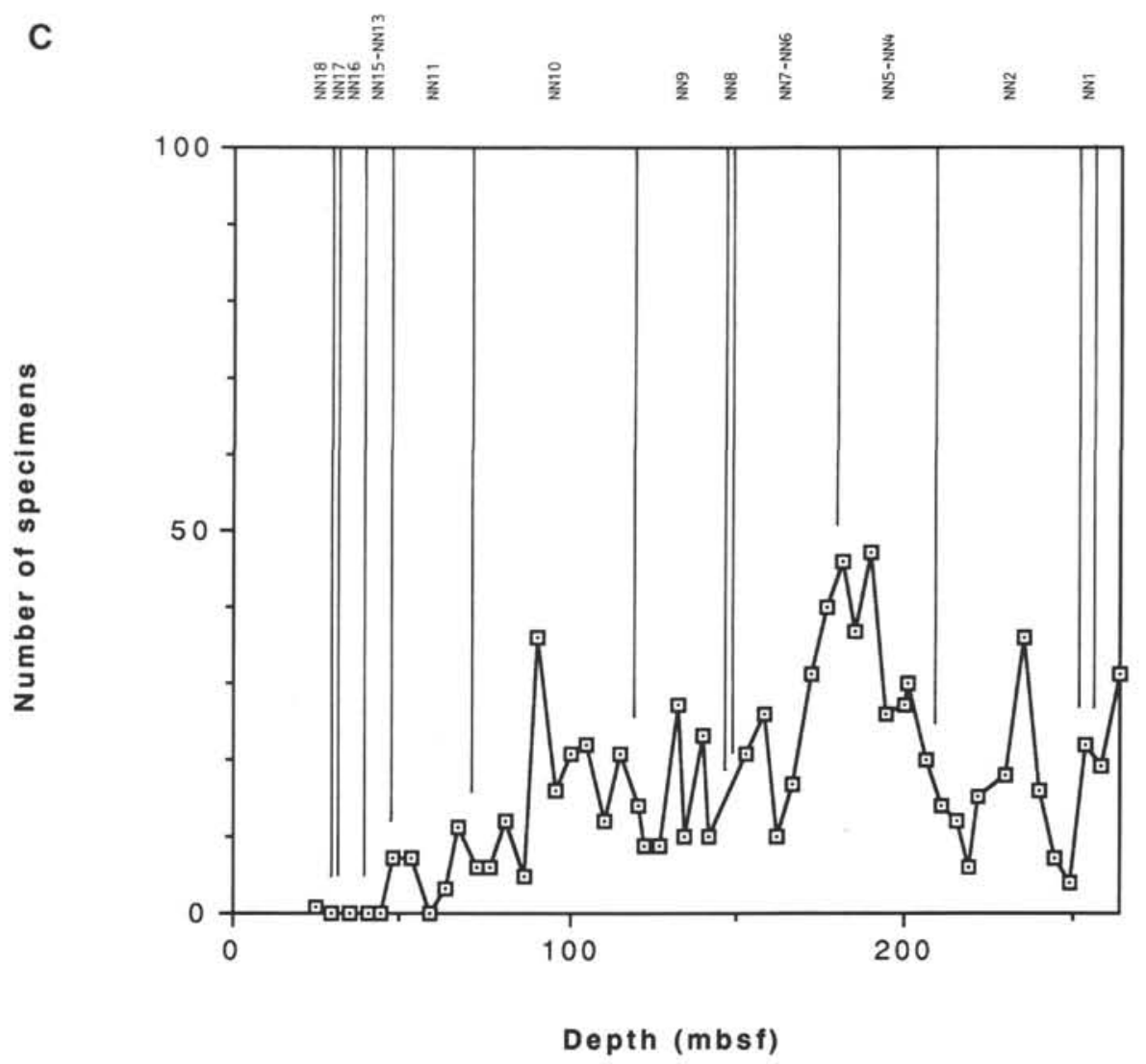

Figure 5 (continued). 
A

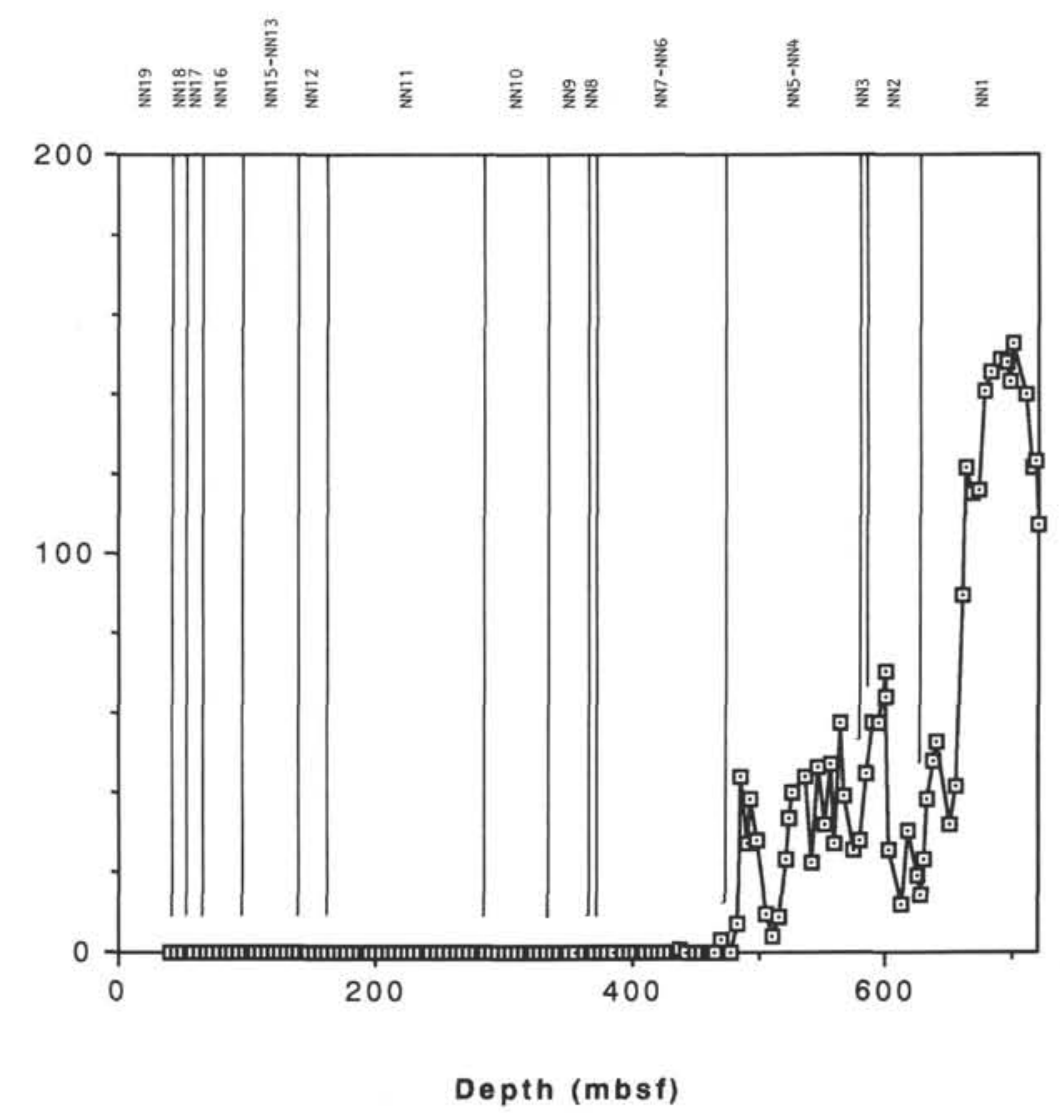

B
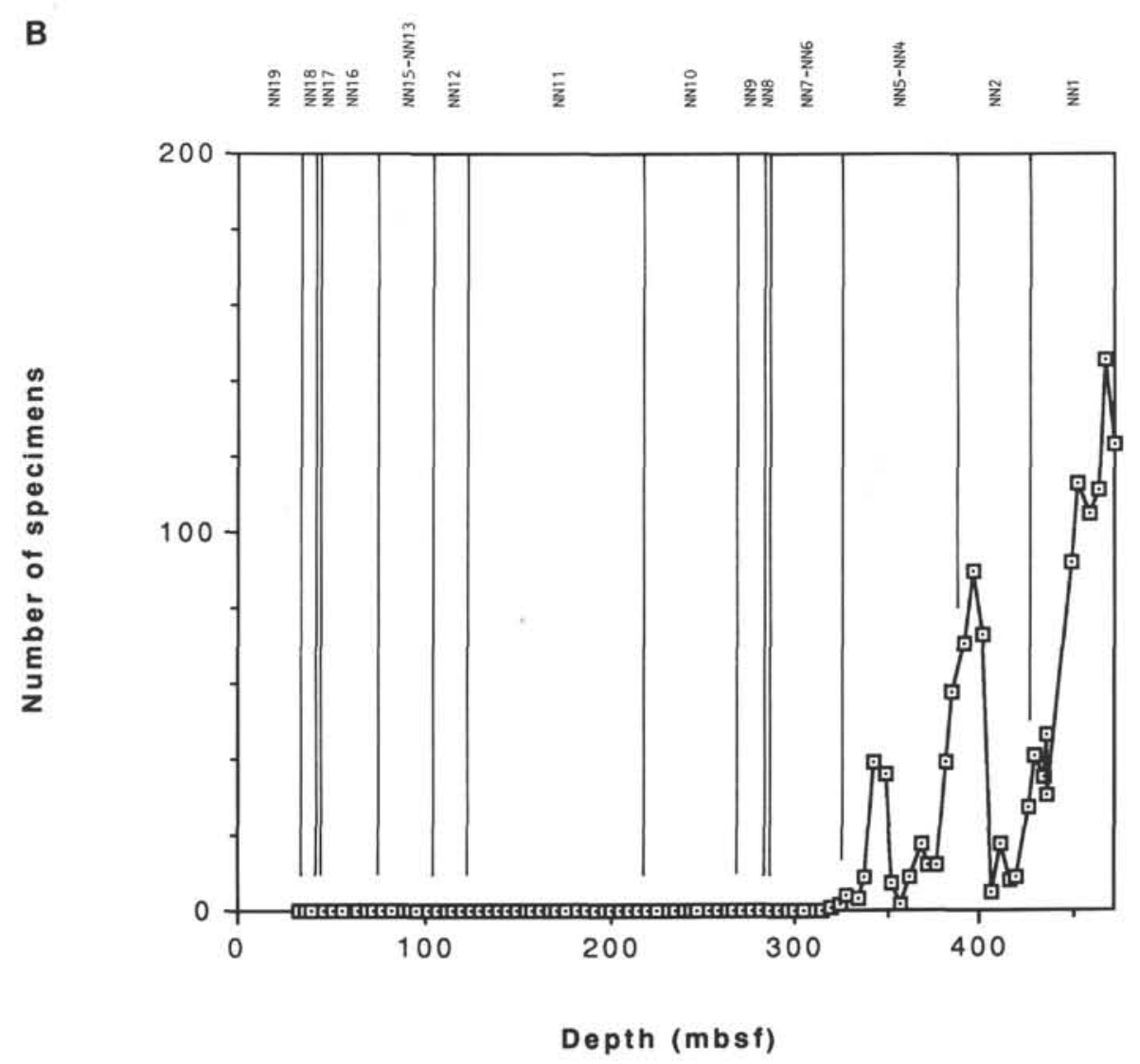

Figure 6. Sequential changes of relative abundance of Cyclicargolithus floridanus in Holes 806B (A), 805B and $805 \mathrm{C}(\mathbf{B})$, and $804 \mathrm{C}(\mathbf{C})$. 


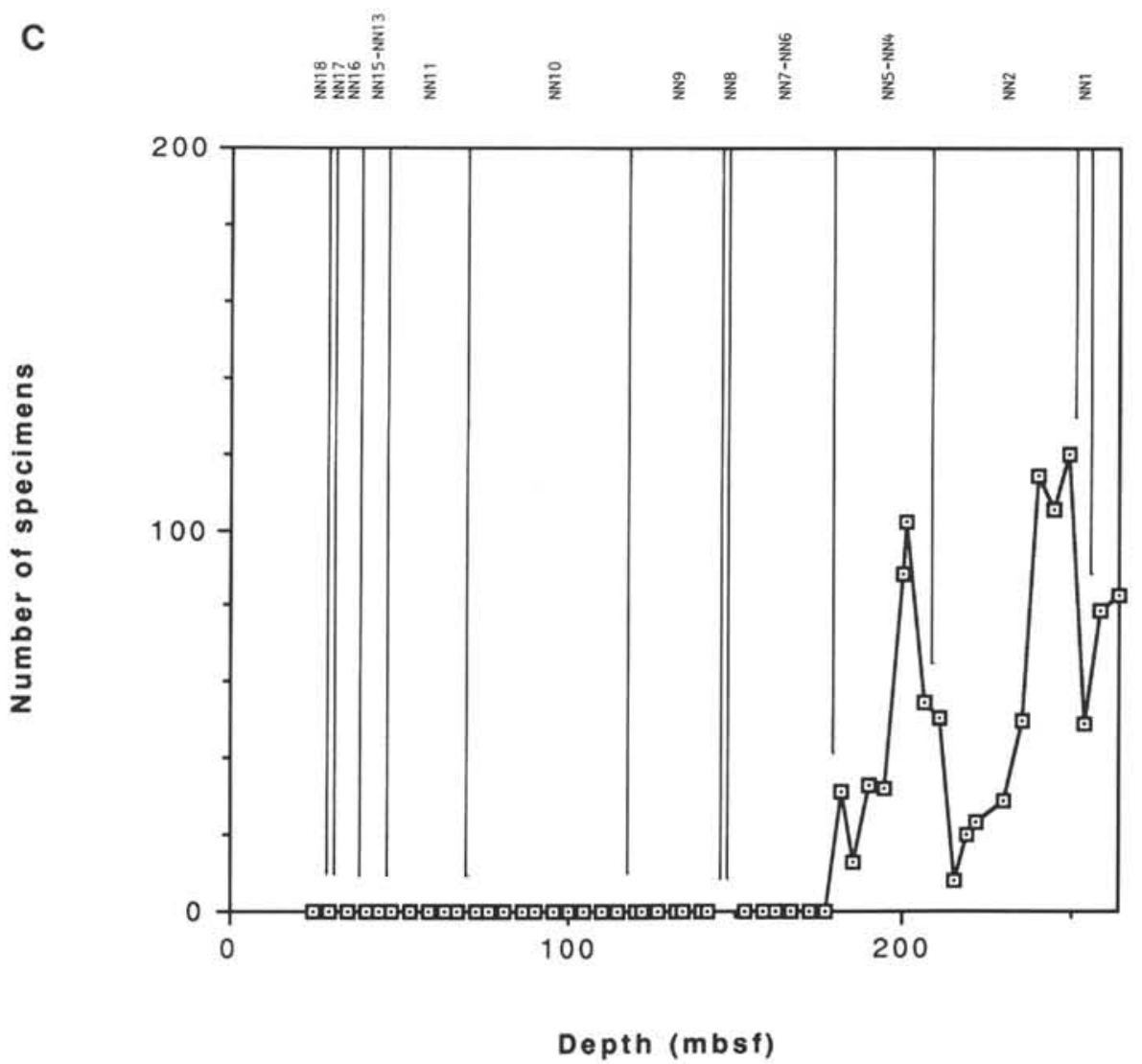

Figure 6 (continued). 
A

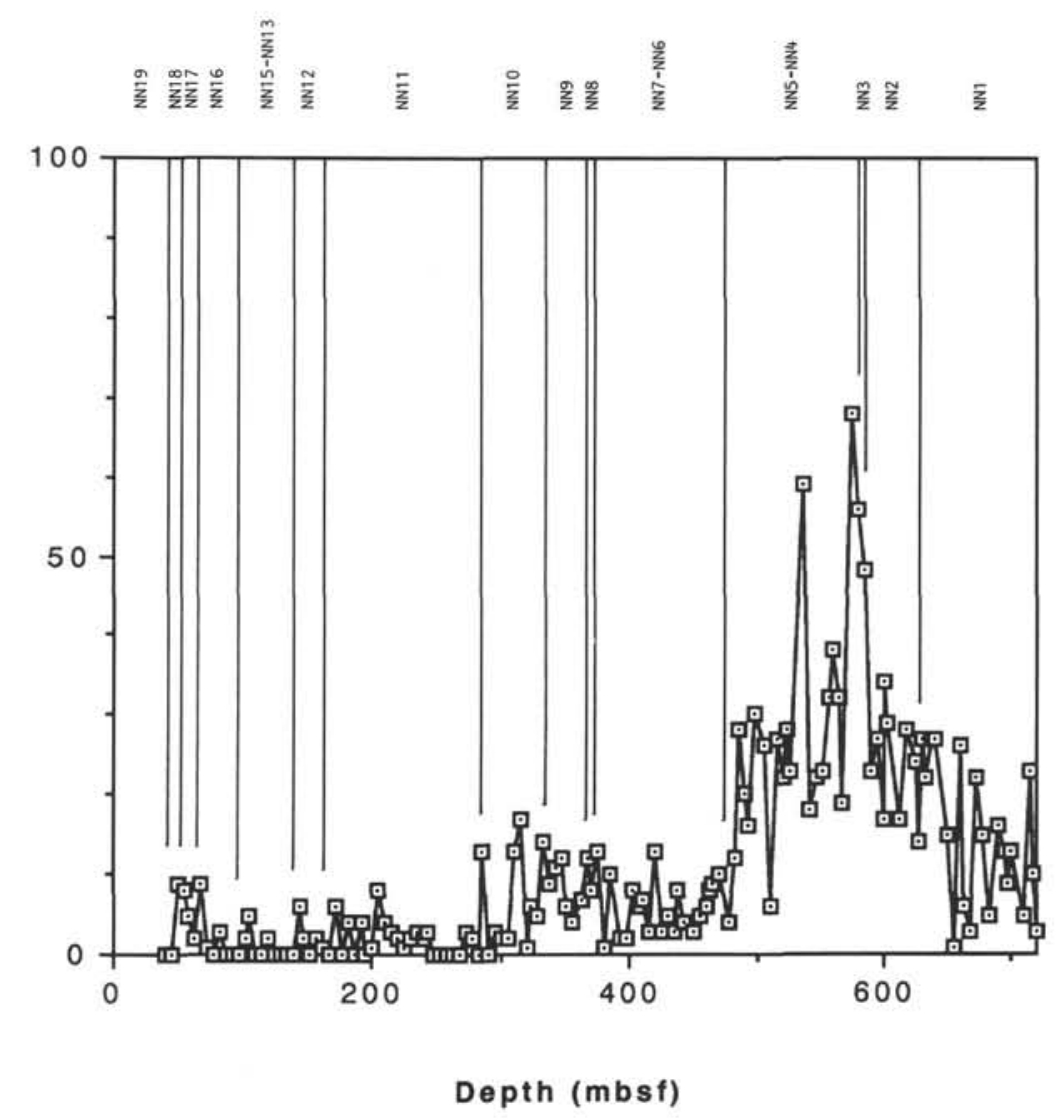

B
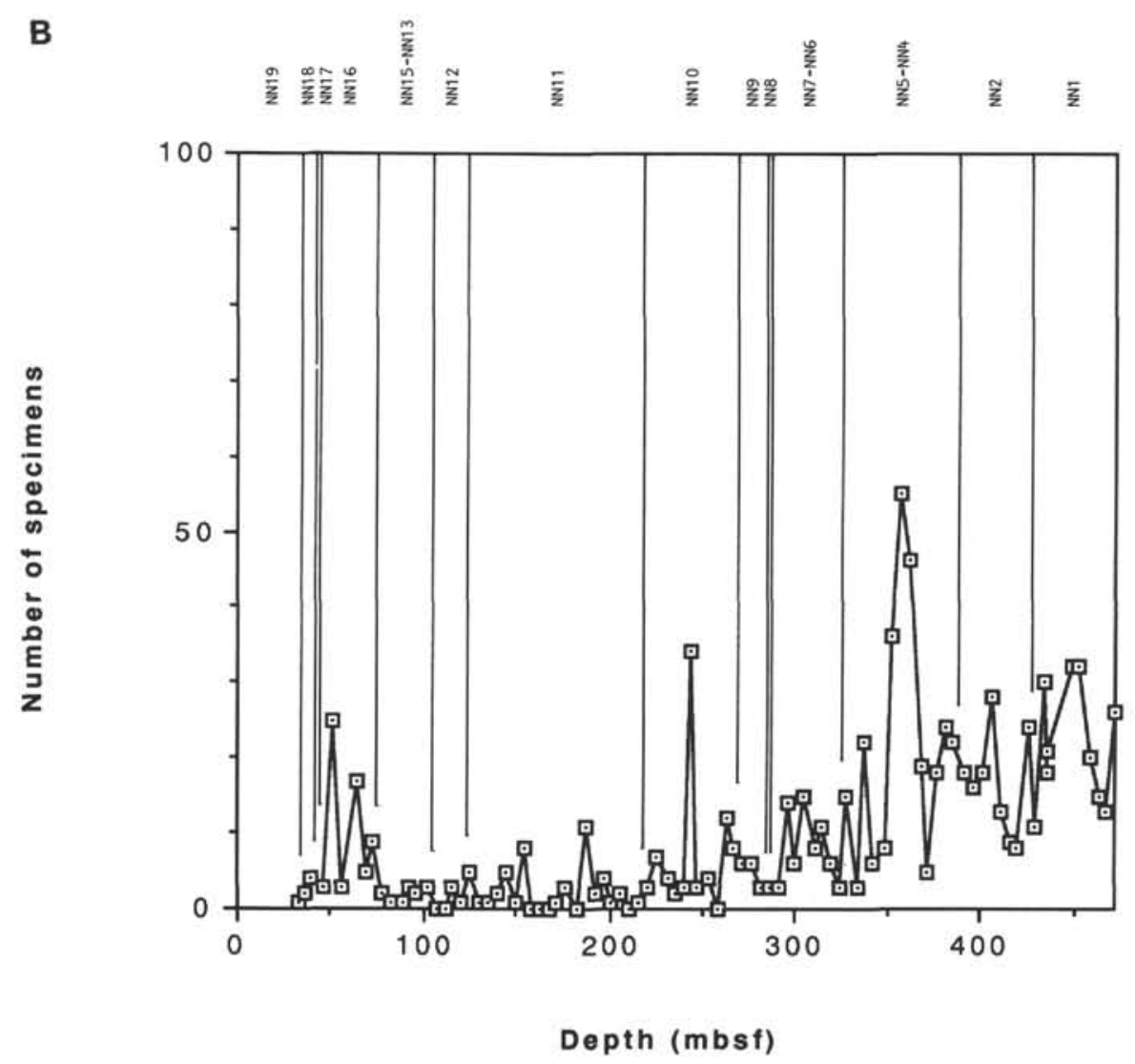

Figure 7. Sequential changes of relative abundance of discoasters in Holes $806 \mathrm{~B}(\mathrm{~A}), 805 \mathrm{~B}$ and $805 \mathrm{C}(\mathbf{B})$, and $804 \mathrm{C}(\mathrm{C})$. 
T. TAKAYAMA

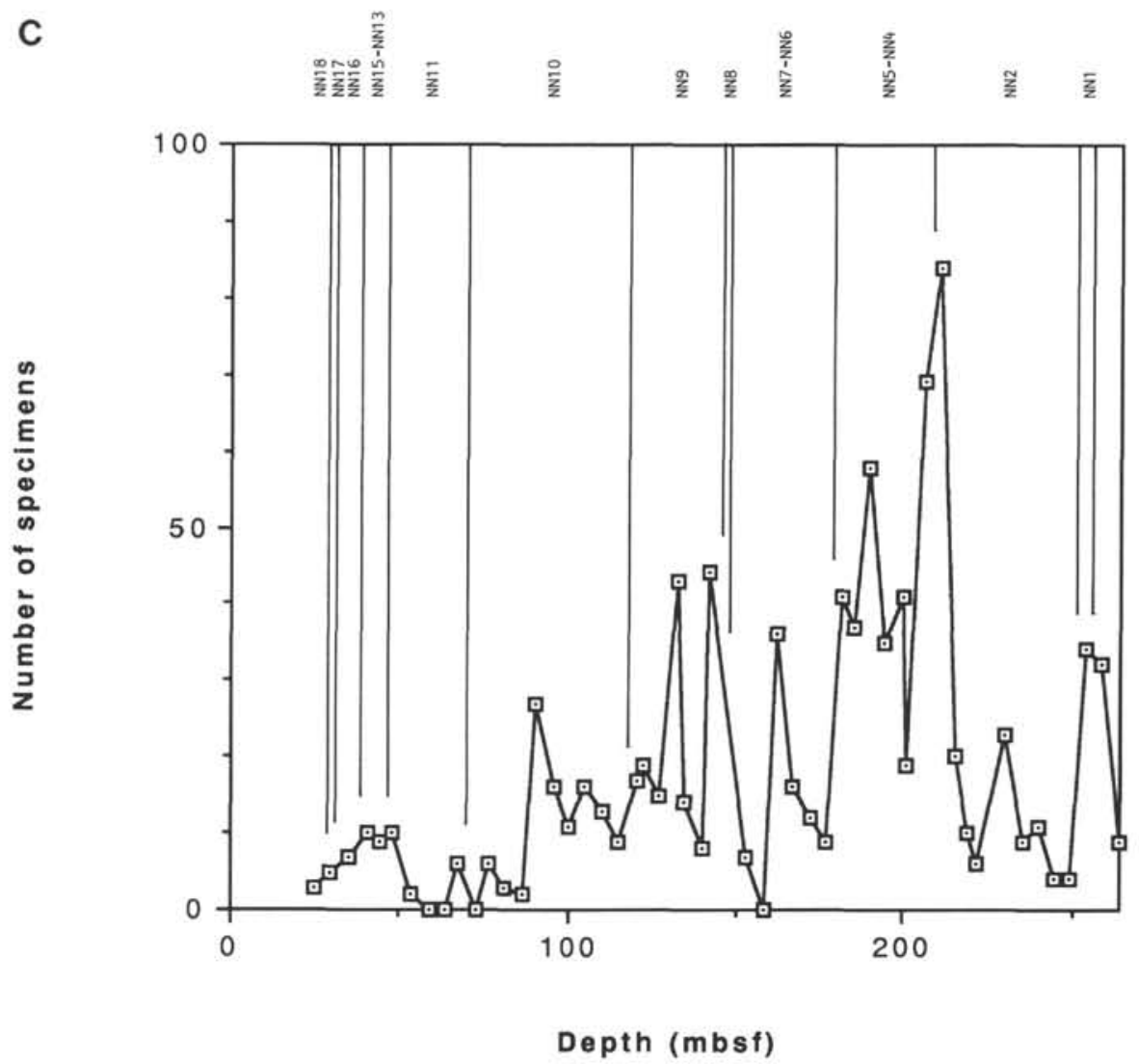

Figure 7 (continued). 
A

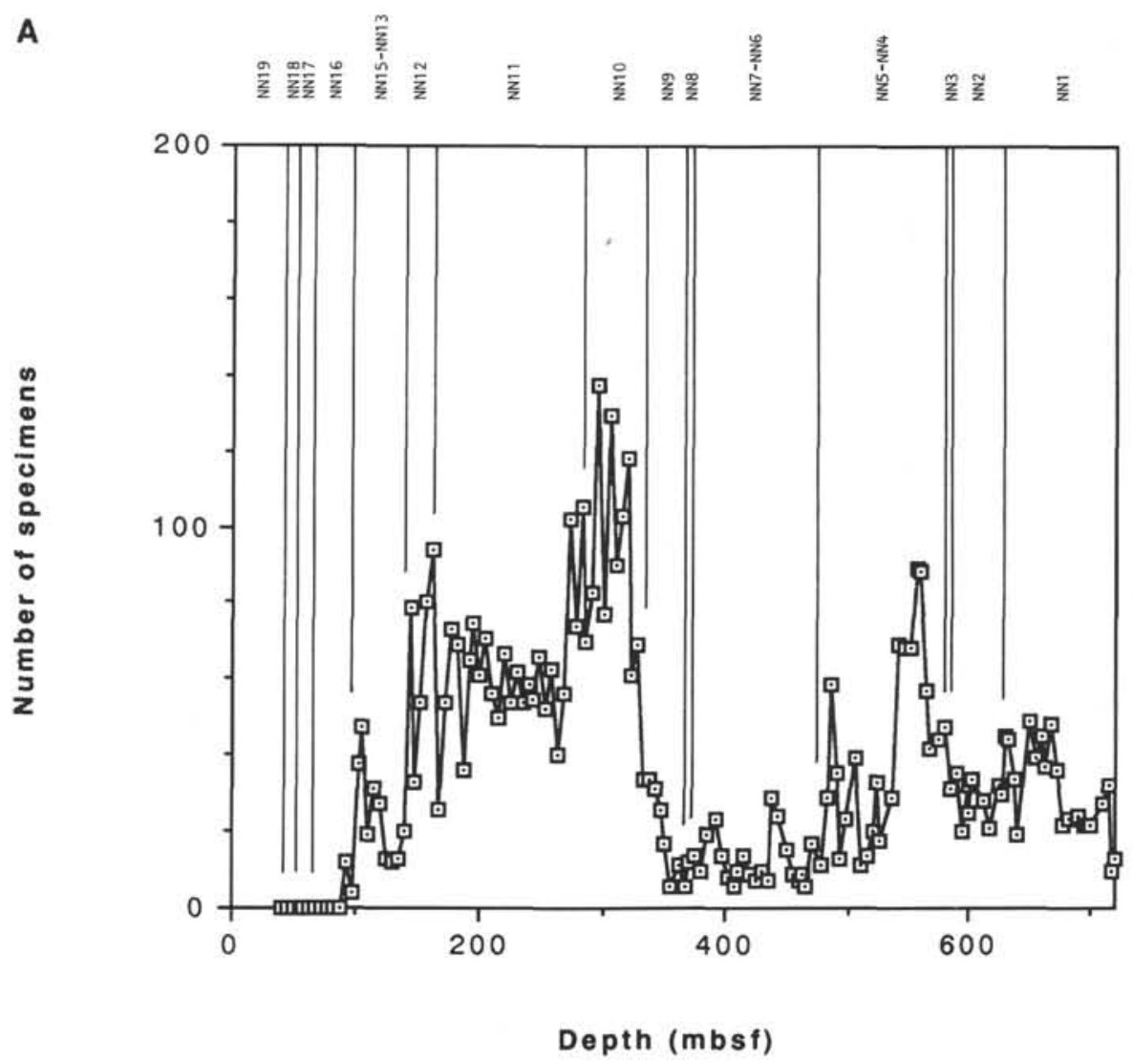

Depth (mbsf)

B

B

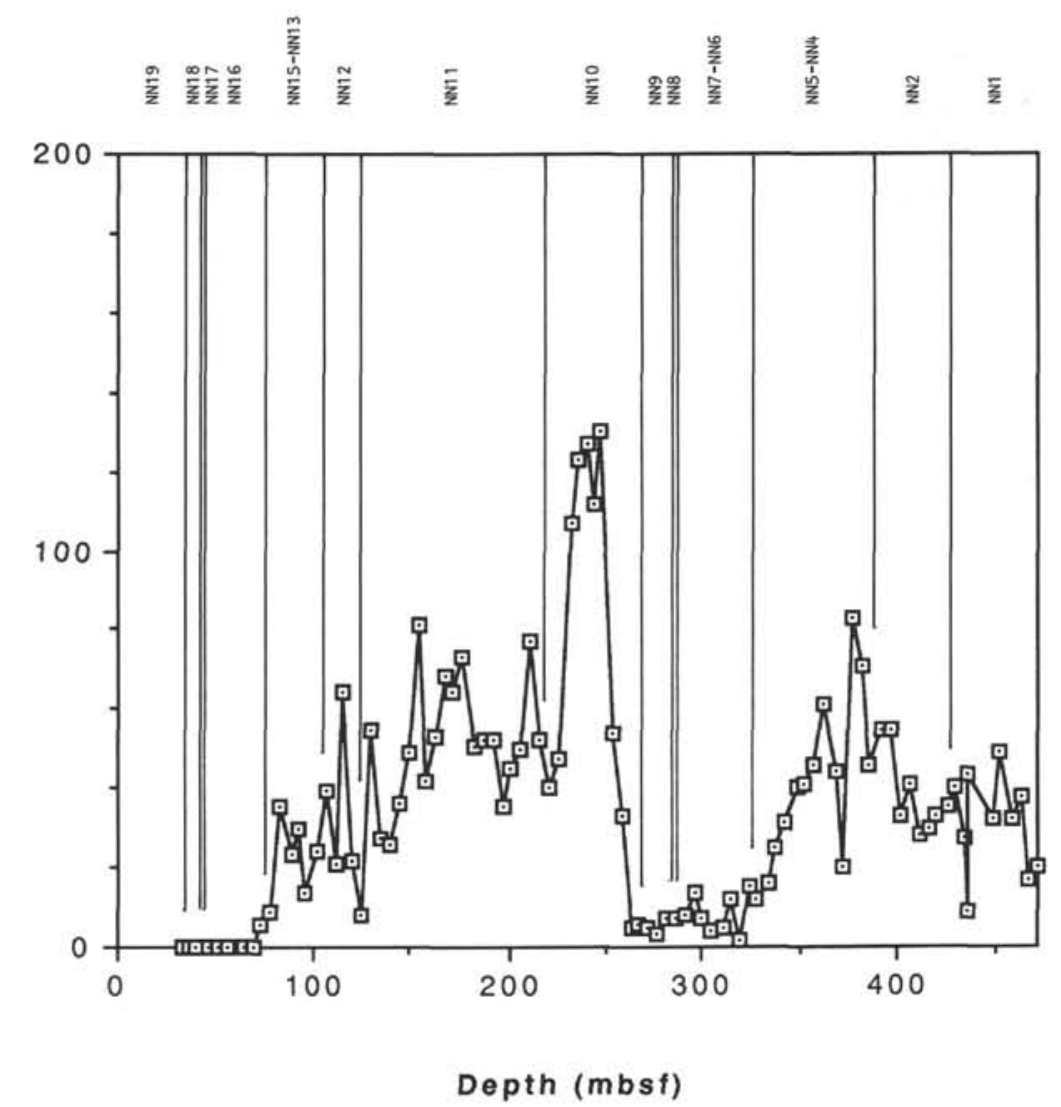

Figure 8. Sequential changes of relative abundance of Sphenolithus spp. in Holes 806B (A), 805B and 805C (B), and $804 \mathrm{C}(\mathrm{C})$. 


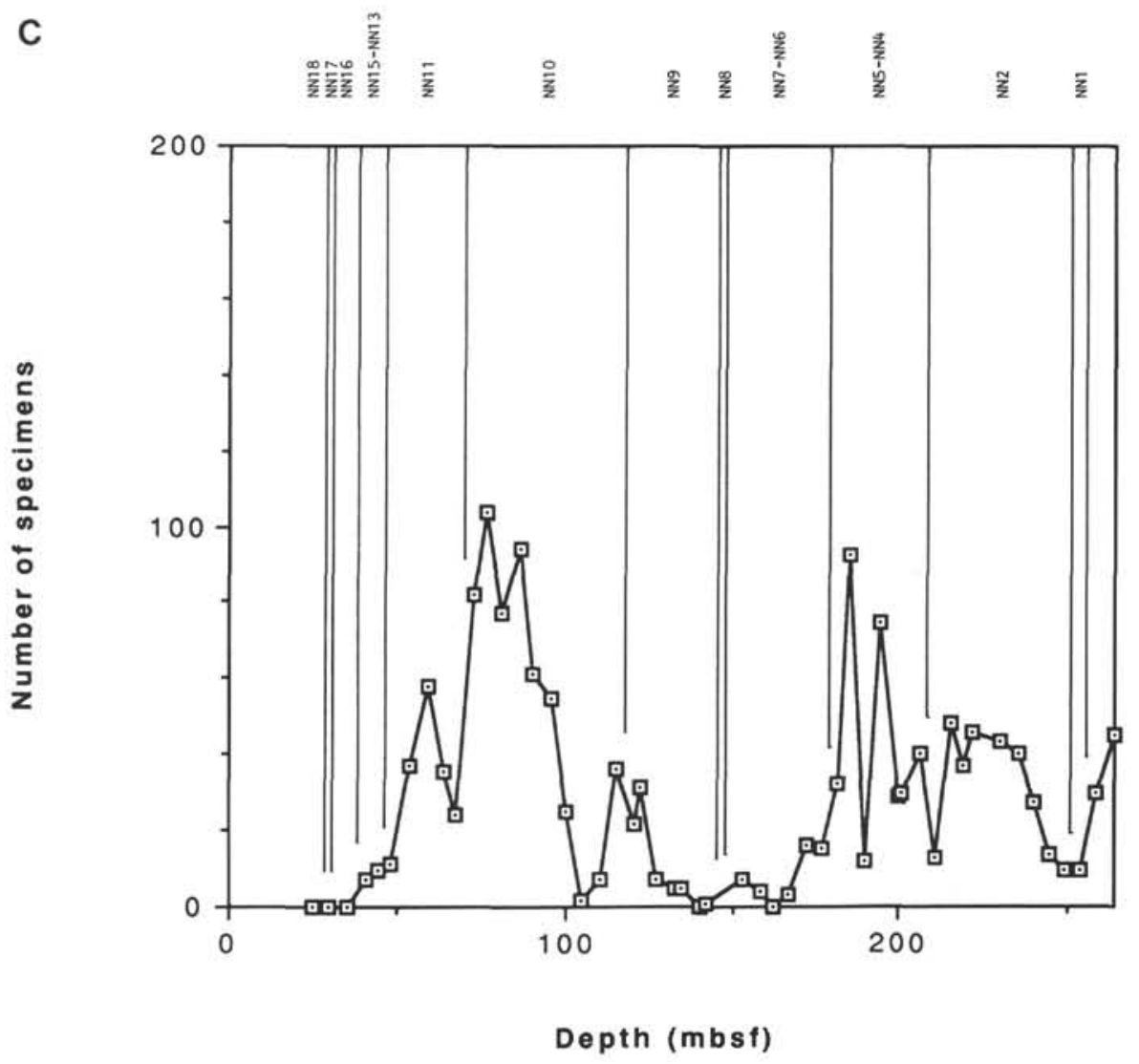

Figure 8 (continued). 
A

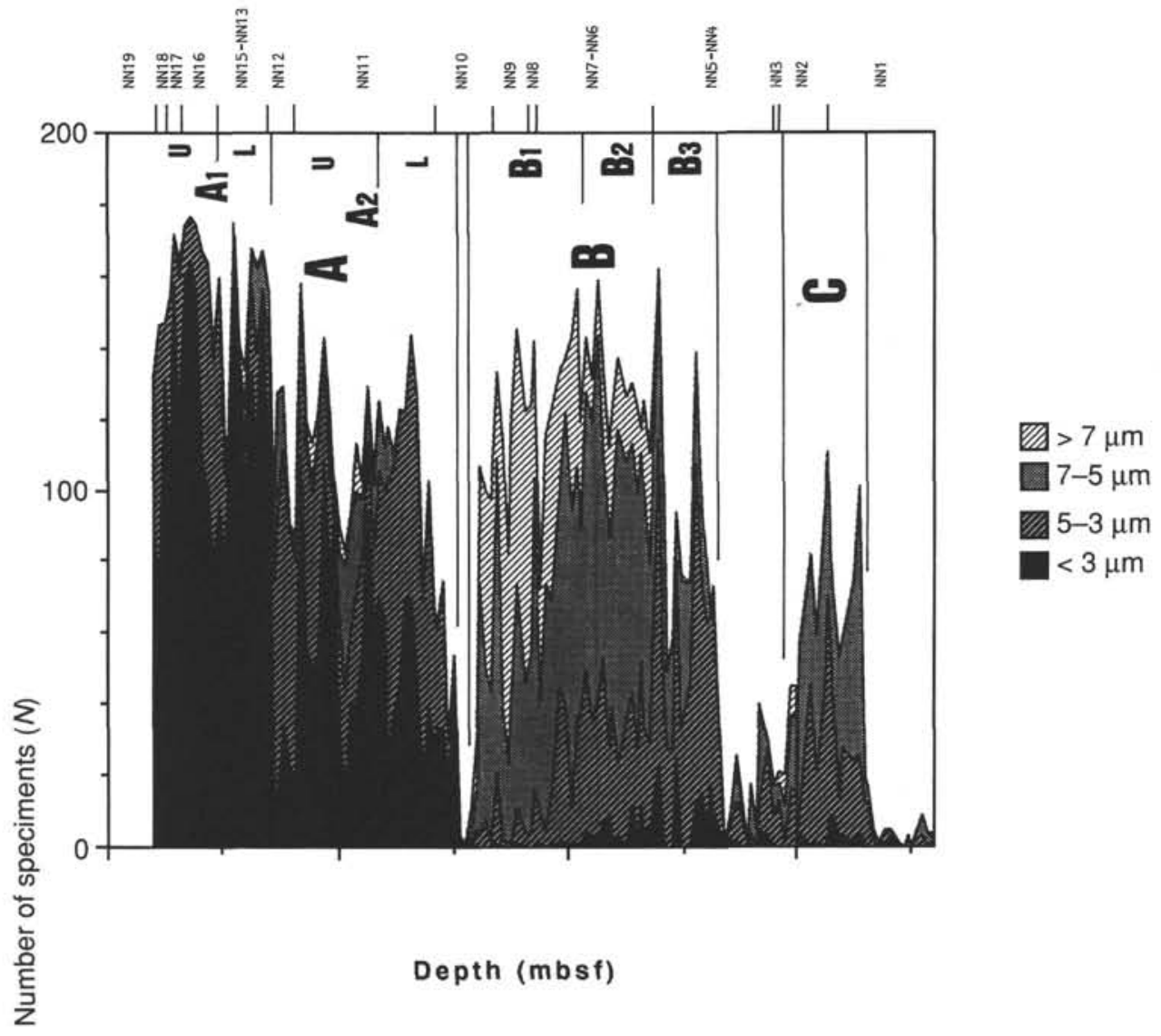

B

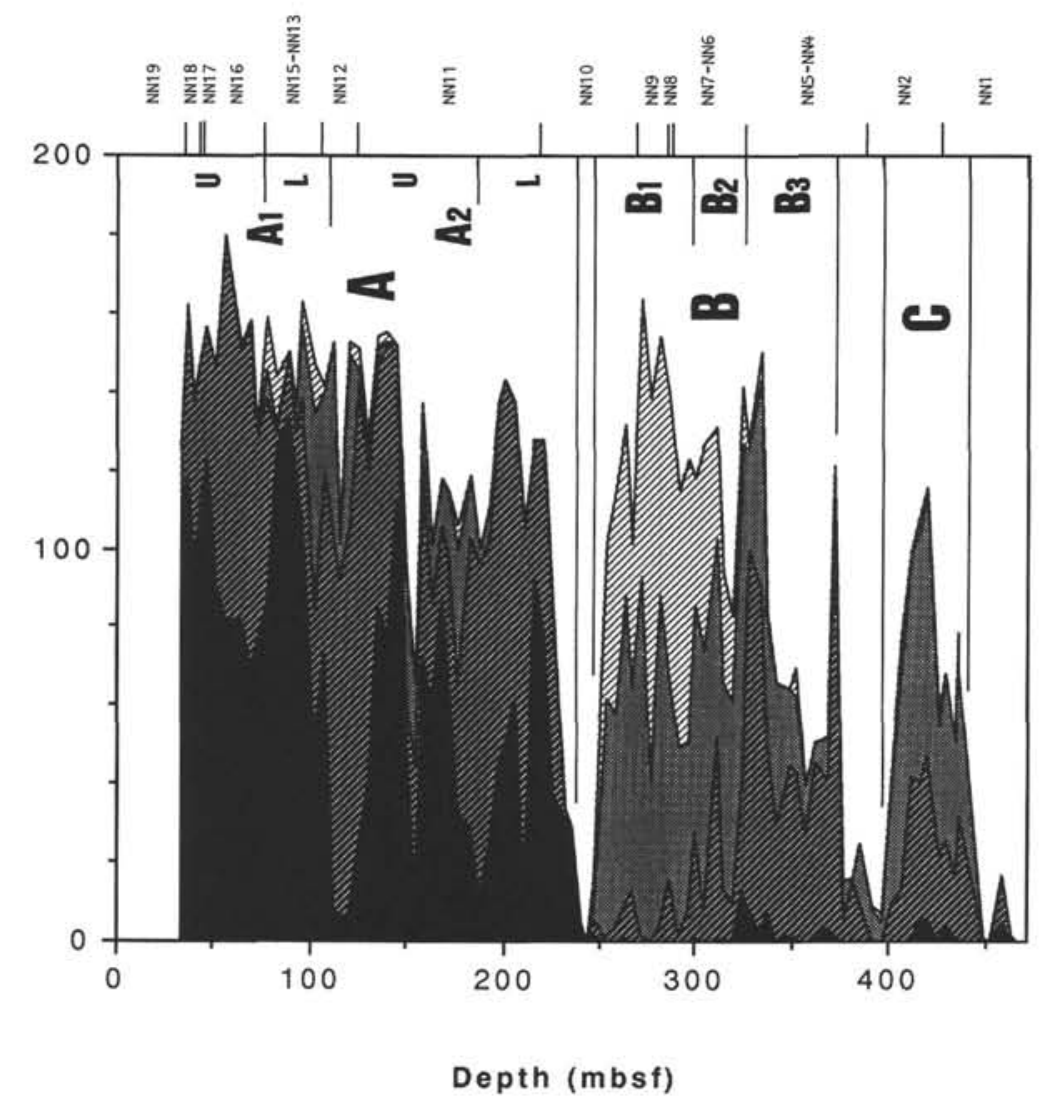

Figure 9. Sequential changes of relative abundance of Reticulofenestra and its coccolith size variation in Holes $806 \mathrm{~B}$ (A), 805B and 805C (B), and 804C (C). 
T. TAKAYAMA

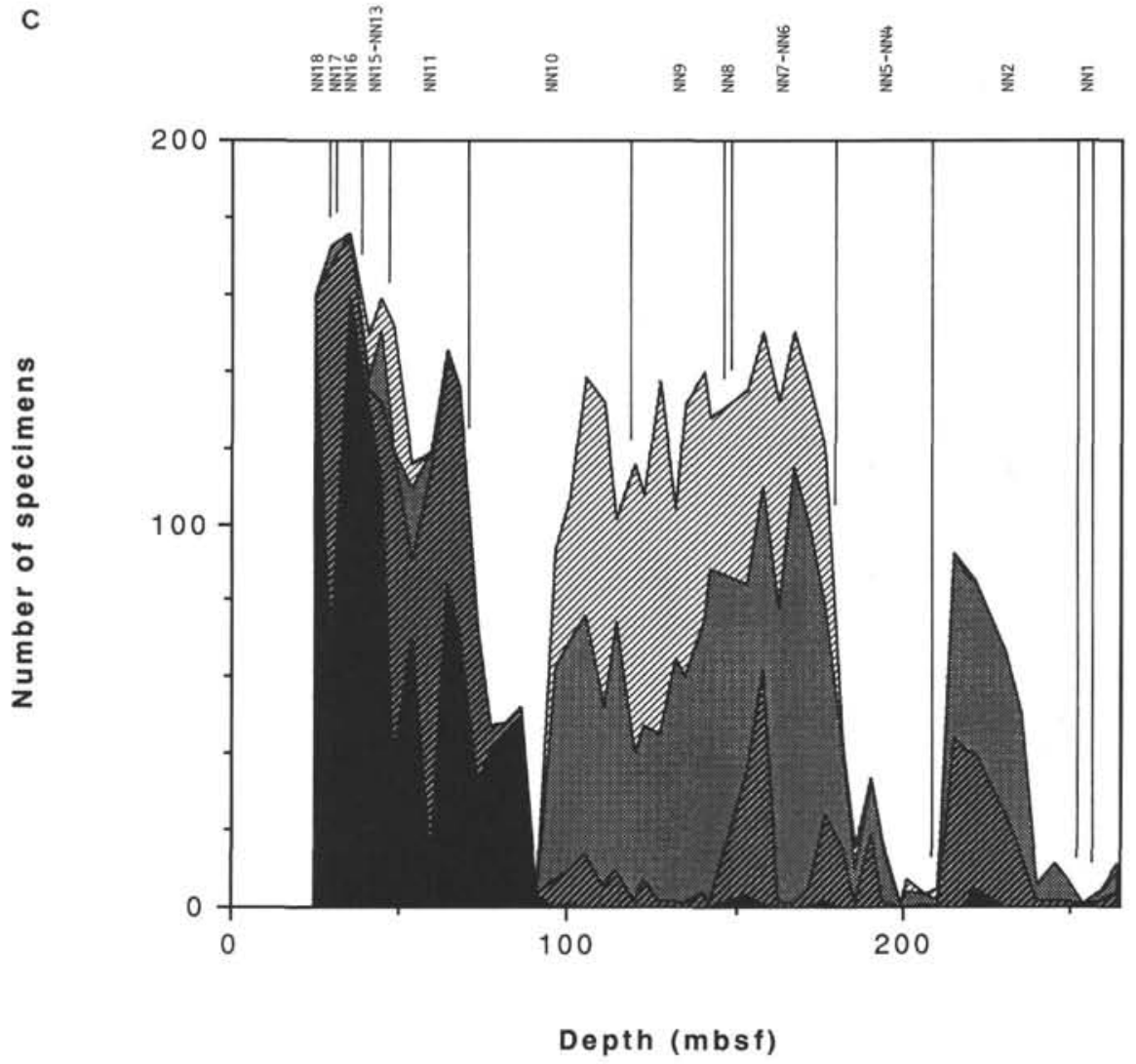

Figure 9 (continued). 
A

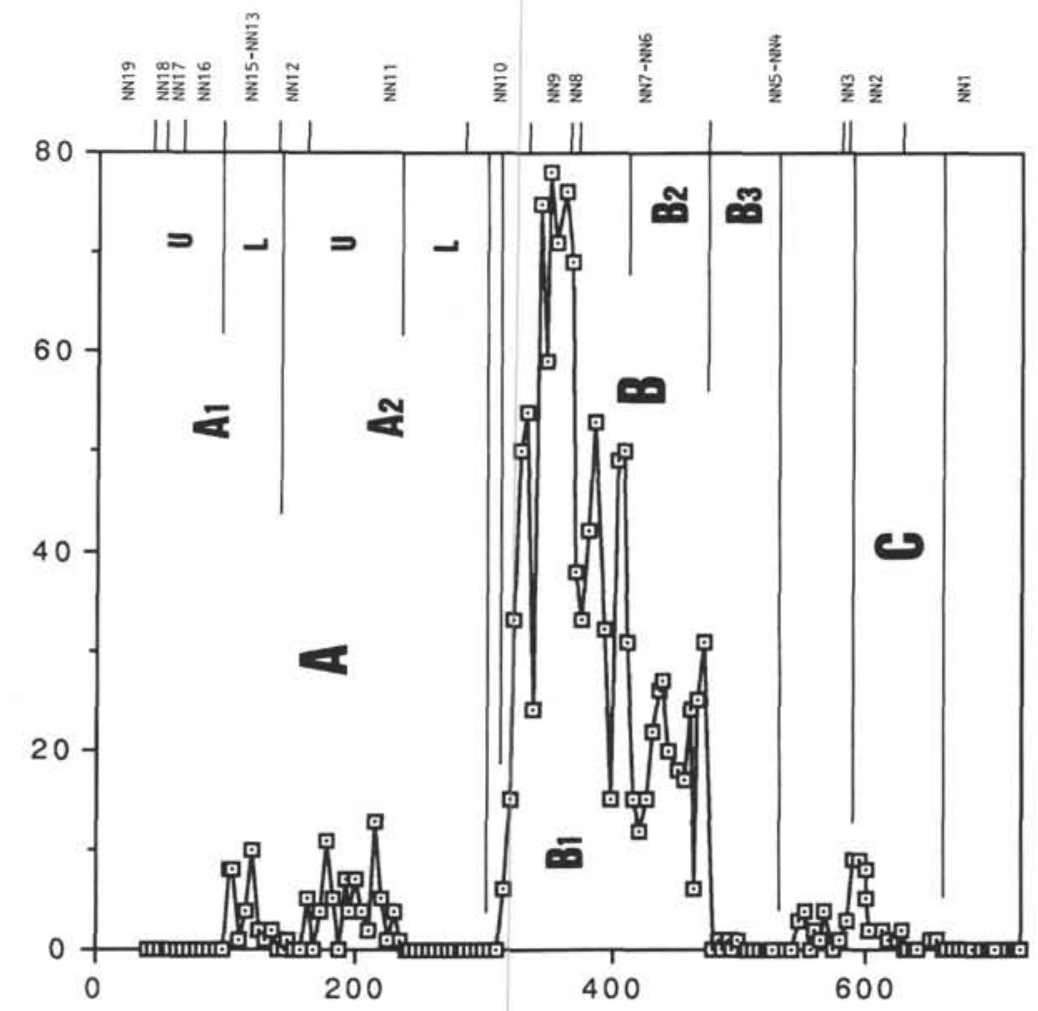

Depth (mbsf)

B

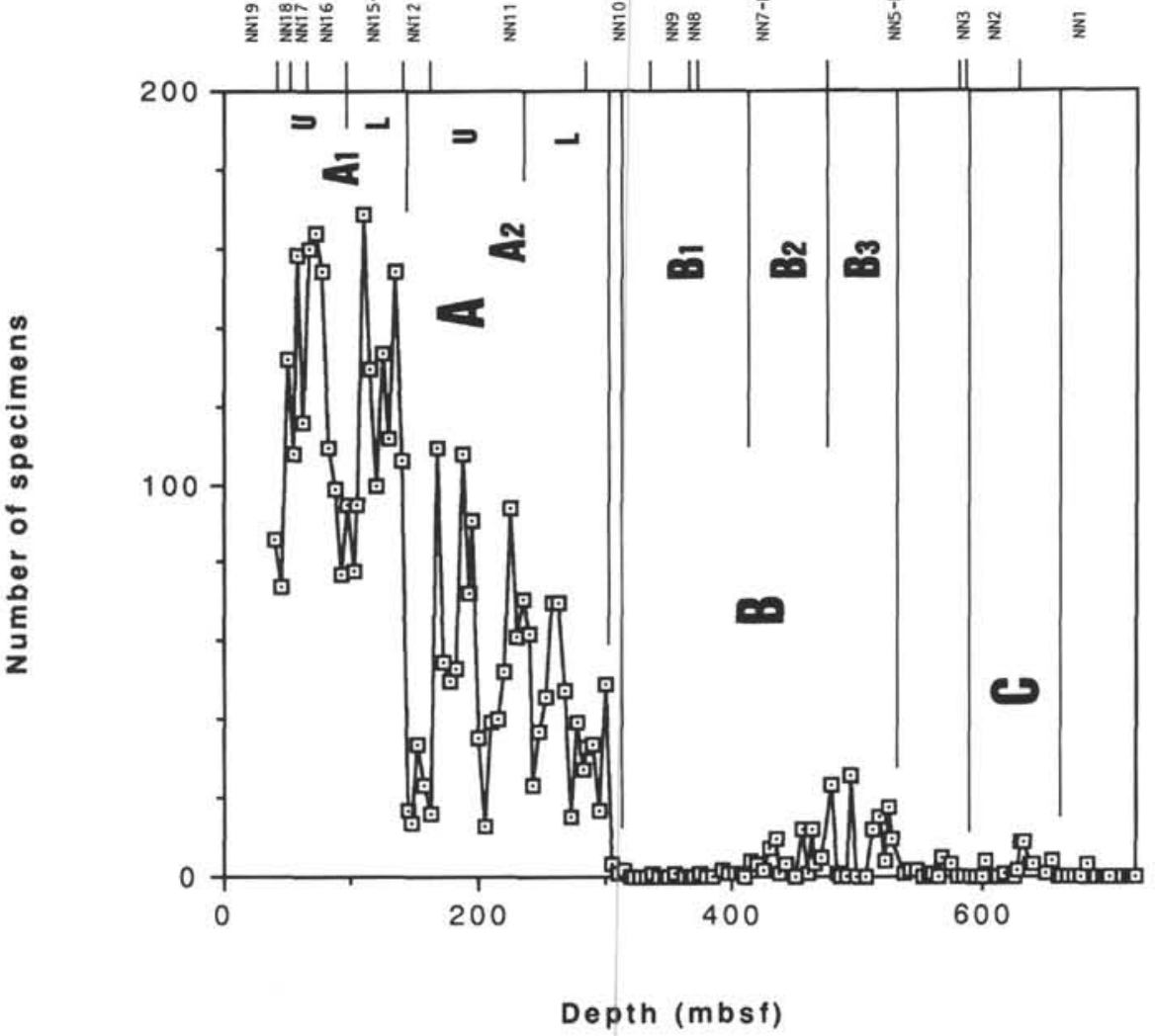

Figure 10. Sequential changes of relative abundance of very large reticulofenestrid coccolith (A) and very small reticulofenestrid coccolith (B) in Hole 806B. 